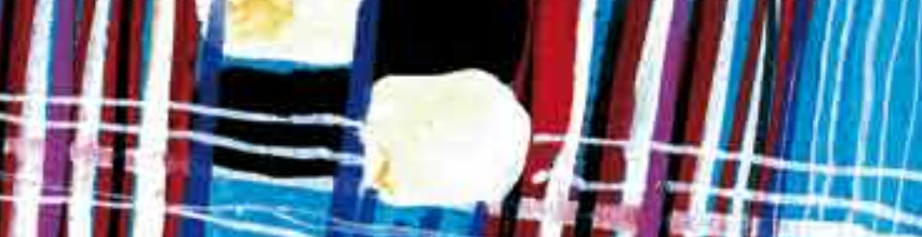

11)

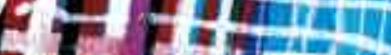
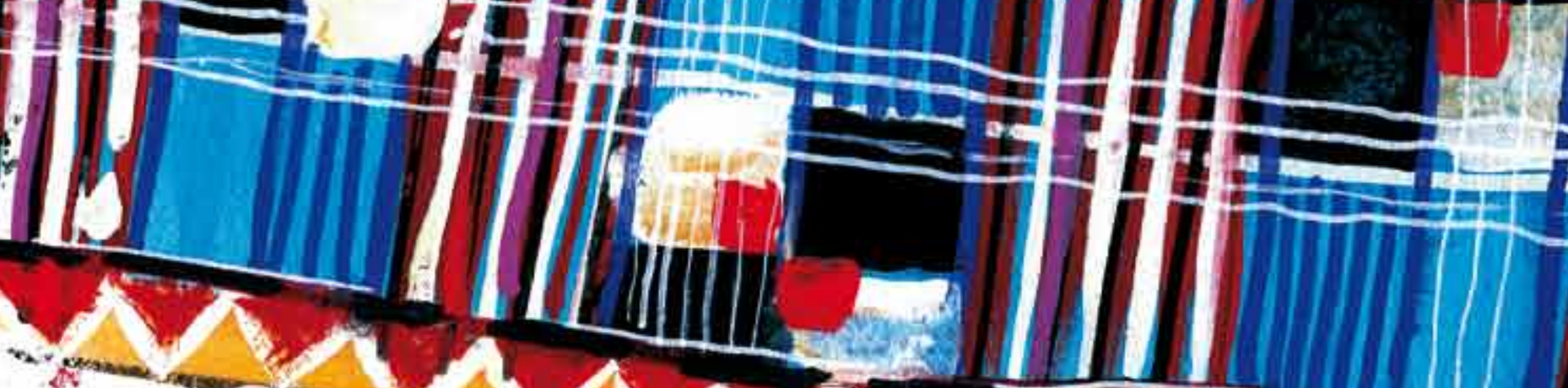

a.
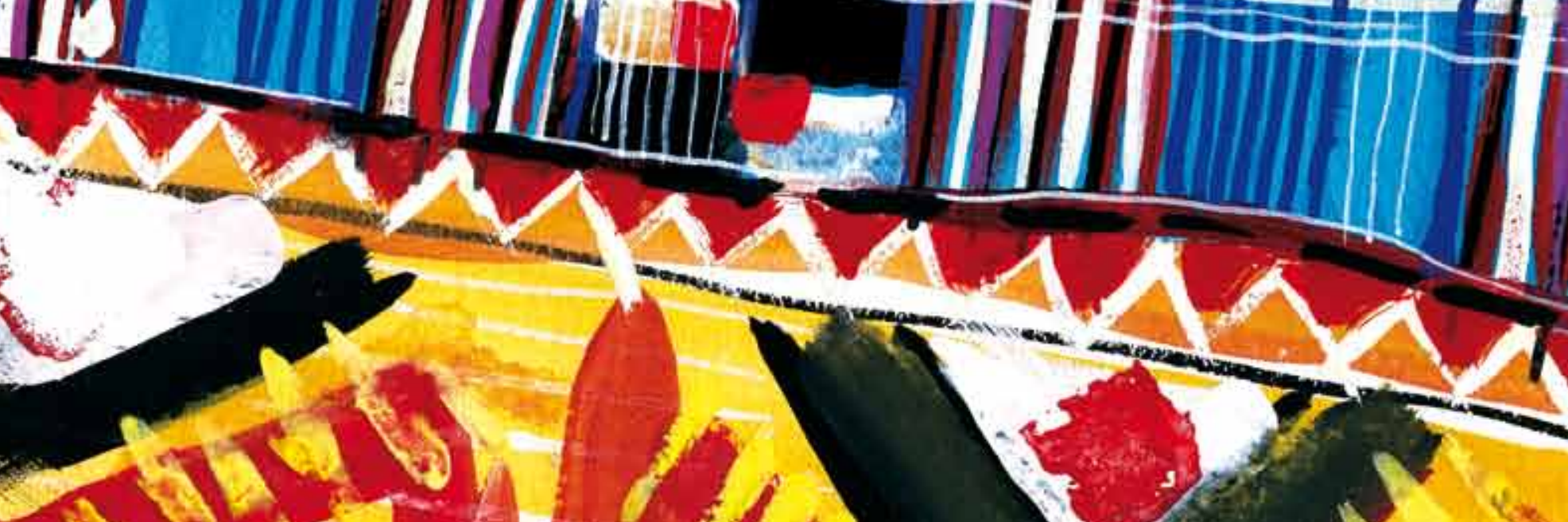

$\rightarrow$

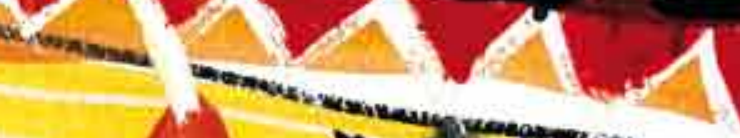

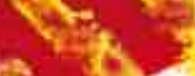

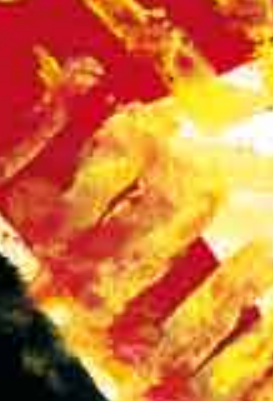

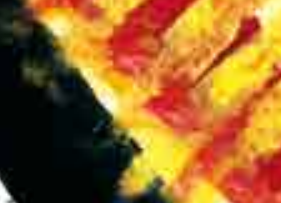

.

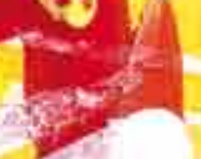

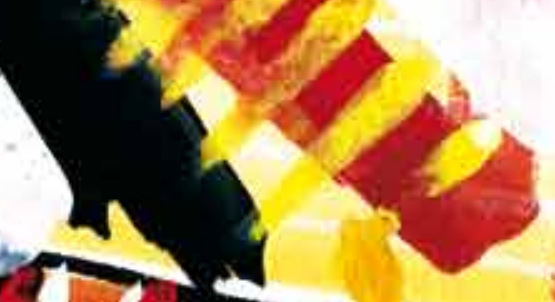
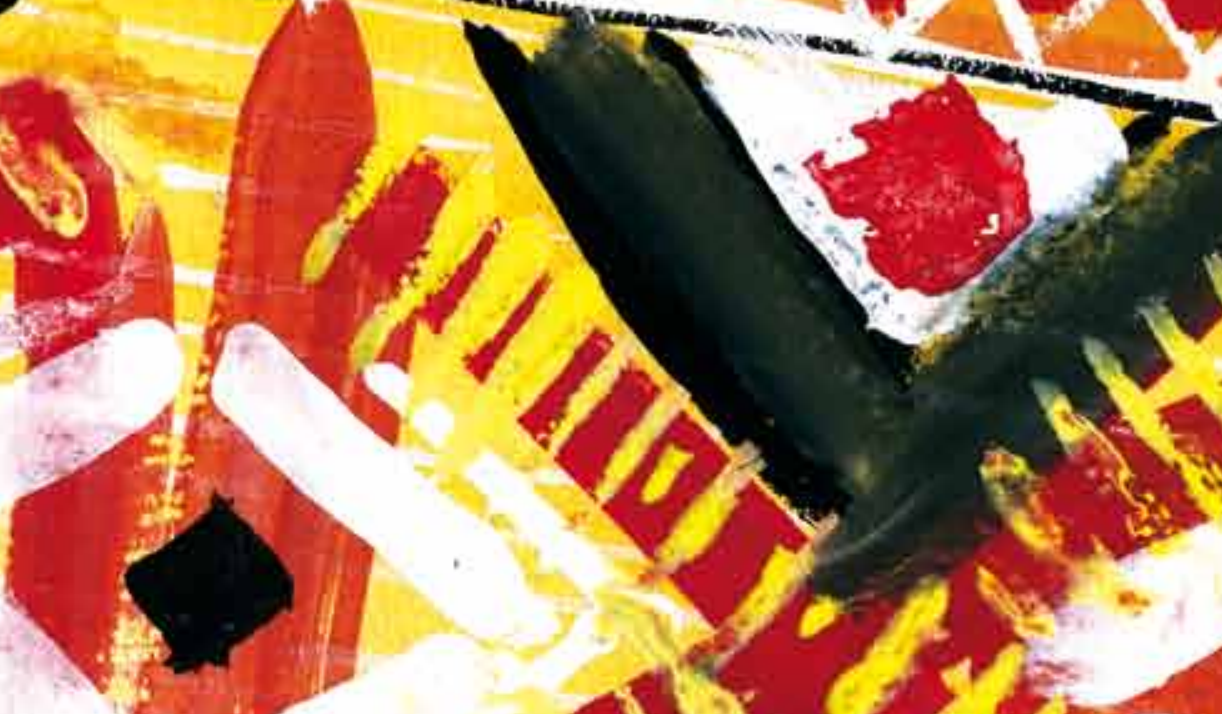

$-2^{2}-x^{2}$
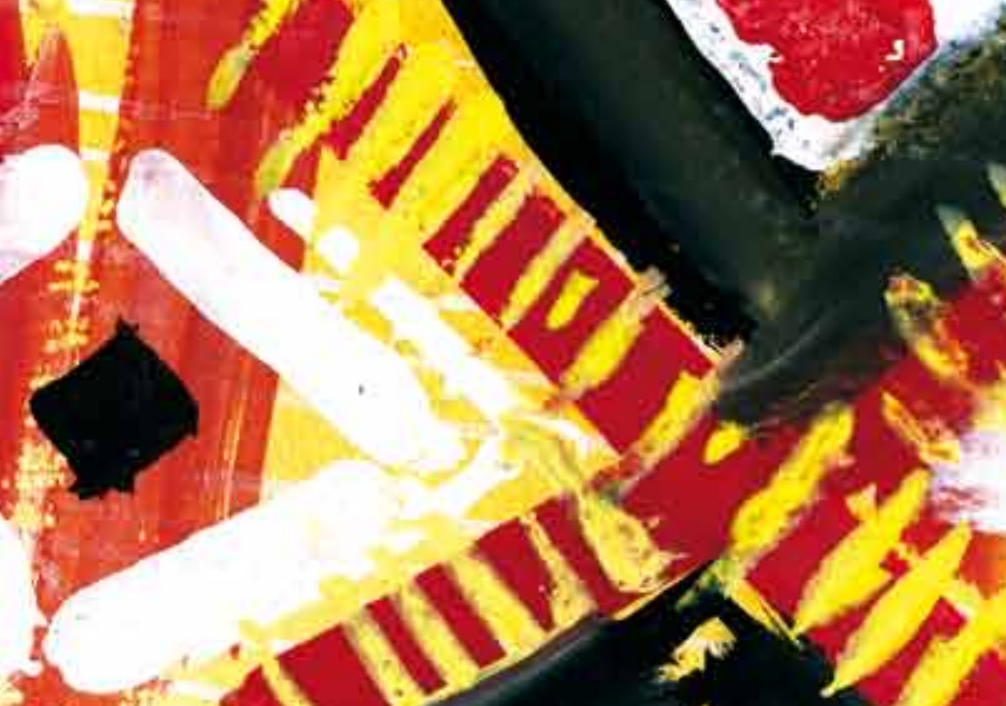

A

Nat 28

1012
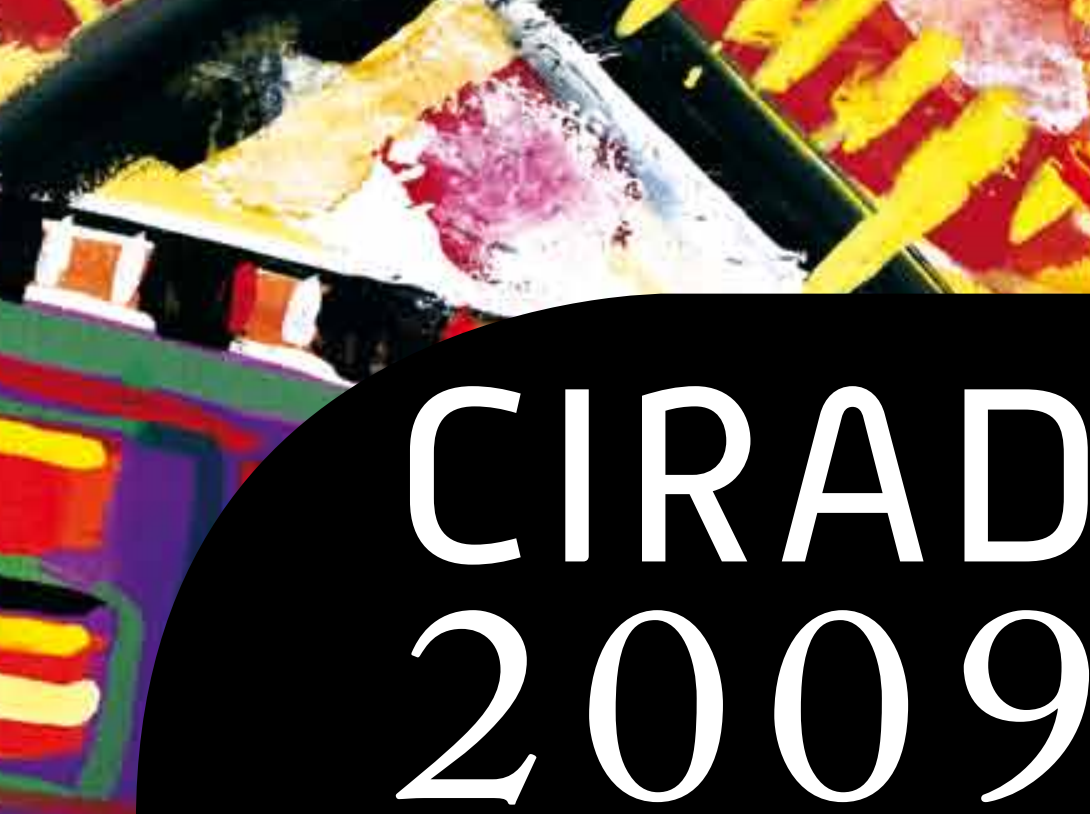


\section{CIRAD 2009}

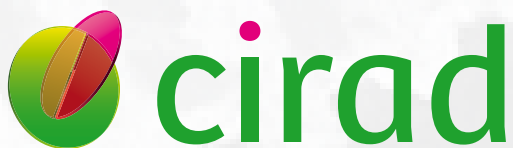

AGRICULTURAL RESEARCH FOR DEVELOPMENT

CIRAD is a French research centre working with developing countries to tackle international agricultural and development issues.

With those countries, it works to generate new knowledge, support agricultural development, and contribute to the debate on the main global issues concerning agriculture, food and rural territories.

CIRAD has a global network of partners and regional offices, from which it conducts joint operations with more than 90 countries.

It has a staff of 1800 , including 800 researchers. It has an annual budget of 214 million euros, with two thirds provided by the French government. 
he past three years have seen the restructuring of our departments and the creation of a collegiate scientific management system. For most of our research departments, 2009 has been an important year, spent preparing for evaluations, which are now to be carried out by the AERES. The Science Council, whose mandate is coming to an end, has supported the establishment's scientific strategy over the past three years, which have been rich in fruitful discussions, by conducting analyses and making precise recommendations on the best ways to make the necessary strategy decisions. For the first time in its history, the Science Council met in Burkina Faso. The CIRAD-INRA Joint Ethics Committee, which was set up in January, has issued its first two statements.

Twenty-five regional or national platforms, backed up by research centres, universities and the international research system, have been identified as priorities in Africa, Asia and Latin America. Naturally, Africa is the favoured continent for implementing the organization's mandate and applying the principles that guide the work of its research teams: research in partnership, capacity building, and development. Around fifteen platforms were identified on the continent; they are elements in the very varied landscape of African agricultural research landscape and its institutional and scientific players.

The need for closer links between research and higher education is clearer than ever, at least as regards agricultural research. CIRAD is working towards this in every country where it is implementing its strategy in association with its partners. In France, a major step has been taken with the founding of Agreenium, a public-sector scientific cooperation establishment (EPCS) for agriculture, food, the environment and sustainable development, which associates our organization with INRA and four higher agricultural education establishments. Agreenium's mandate is to promote what its members have to offer, on an international stage. On a European level, a similar movement is under way: thirty-six universities and scientific organizations involved in agricultural research and education for development have joined forces to set up the Agrinatura alliance, which was born from the merger of the Natura association and the ECART grouping, which was previously headed by CIRAD.

The new momentum generated by the planned Union for the Mediterranean has prompted CIRAD to strengthen its presence in the region, in line with the priority given to it by the FI4IAR and Agreenium. An agricultural research cooperation agreement was signed in Tunis in January, between CIRAD, IRESA (Institution de la recherche et de l'enseignement supérieur agricoles) and the University of Sfax.

This year, which is the Year of France in Brazil, has seen the signing by CIRAD and EMBRAPA of a major agreement on training, capacity building and innovation in four fields: advanced biology, particularly plant functional genomics; sustainable development of the Amazon biome, in support of the implementation of the bilateral agreements signed in December 200; public policy and sustainable territorial development for family farms; and tripartite cooperation, particularly involving the least developed countries in Africa.

The PalmElit firm, which was founded following a decision by the Board of Trustees in December 2008, began operations in March. This new instrument, set up to support the organization's scientific strategy, is ensuring the promotion of its work on oil palm genetics. The acknowledged quality of the varieties created is a real step forward for development in producing countries, particularly since PalmElit is drawing up a social and environmental responsibility charter.

This report sets out to reflect as faithfully as possible CIRAD's research results, the changing issues its has to tackle, and its partnerships. Over and above the need for transparency, which concerns each and every public research organization, the report, like the commitment made by every staff member in every year, is intended to serve the humanist values on which CIRAD is founded.

Patrice Debré,

Chair, Board of Trustees
Gérard Matheron,

Director Geneéral

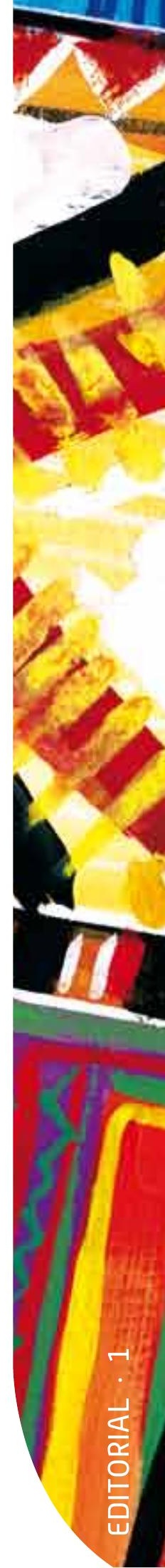




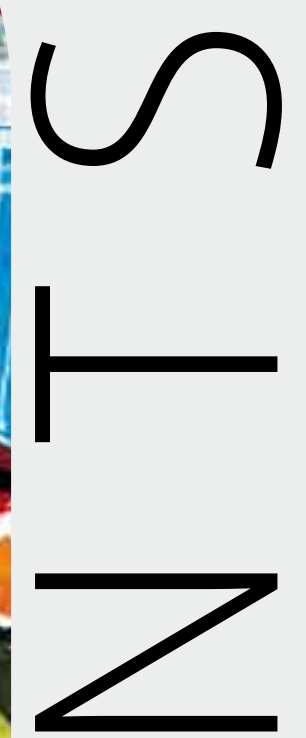

Editorial

\section{INSTITUTIONAL HIGHLIGHTS}

A new geographical partnership strategy for CIRAD 4

Research and education join forces to build the future 6

Training and higher education, an in-depth rethink 6

CIRAD on line 8

Monitoring in support of strategy 8

An information network and a platform on the world's plants 8

A set of references for quality in research 9

Studying and conserving agrobiodiversity in Montpellier 9

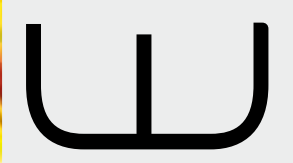

\section{RESEARCH}

Line 1. Ecological intensification 10

The banana streak virus: an extreme case of parasitism 12

Understanding banana domestication: a crucial step

towards improvement

14

$\begin{array}{ll}\text { A dessert banana breeding platform in the West Indies } & 16\end{array}$

Recombination and viral emergence: a begomovirus model 16

$\begin{array}{ll}\text { New citrus rootstocks for the Mediterranean Basin } & 17\end{array}$

$\begin{array}{ll}\text { The first coffee DNA microarray } & 19\end{array}$

Modelling the impact of refuges on pest resistance 20

A coconut hybrid to control lethal yellowing disease in Ghana 21

Sorghum genetic diversity in Duupa farmers' fields 22

Agro-ecological crop protection 23

No-tillage with cover crops for the Brazilian Cerrados 24

Cocoa mirid control recommendations 26

Collaborative statistics on livestock in southern Africa 27

Line 2. Biomass energy 28

Jatropha curcas, a fuel of the future for the South? 30

Producing charcoal for energy purposes by pyrolysis 32

Managing the sustainable fuelwood resource in Central Africa 33

Producing energy from biomass in à Madagascar 34

$\begin{array}{ll}\text { Biofuels for professional fisheries } & 35\end{array}$ 
Line 3. Food

Fonio, the rediscovery of a traditional cereal

Disseminating new quality foods in Vietnam and Laos

Camargue aromatic rice

Food security: combining tools to stabilize prices

What is the environmental impact of food products?

\section{Line 4. Animal health, emerging diseases}

African swine fever: a threat to livestock herds in tropical countries

Climate change and emerging animal diseases

An epidemiological risk management network in South-East Asia

CaribVET: the Caribbean Animal Health Network

Culicoides surveillance in France

\section{Line 5. Public policy}

Feeding the world in 2050: an achievable goal, according to the Agrimonde foresight study

Assessing the sustainability of fish farming systems

Private goods and public services: the need for compromise

Animal production, the treasure of the poor

Large-scale land investments

Responding to climate change: building local and national capacity

\section{Line 6. Rural areas}

Understanding the role of tropical rainforests in the carbon cycle Monitoring forest dynamics in Central Africa

Forests of the Congo Basin

Sustainable management of baobabs in Madagascar

Imogolites: natural nanoparticles that sequester nickel

Controlling nitrate pollution risks in Réunion

Locust outbreaks in Madagascar: predicting risks

to enhance their management

Saving water in North African irrigated farming systems
40

41

43

44

46

47

48

48

49

50

52

54

56

58

58

59

60

62

64

64

65

66

68

69

70
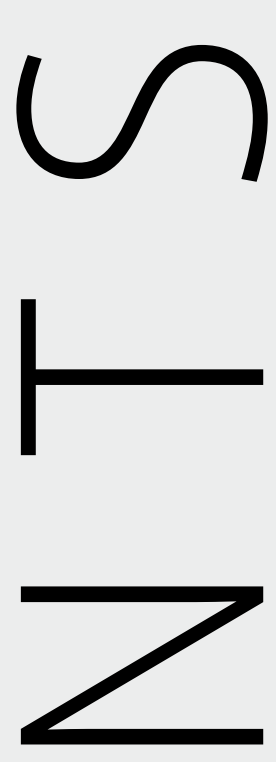

ㄴ.
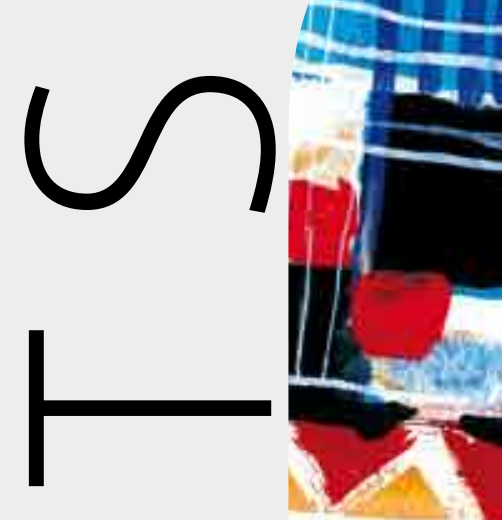

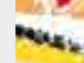
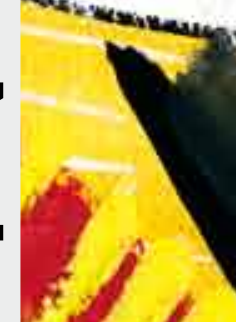

50

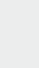
(5) 8 9
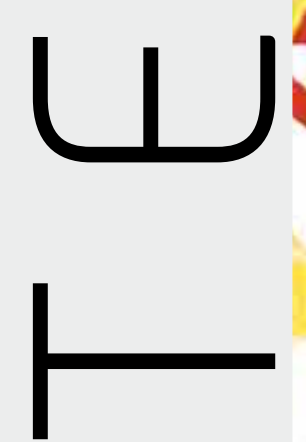
.

4 65 66 8 9 0
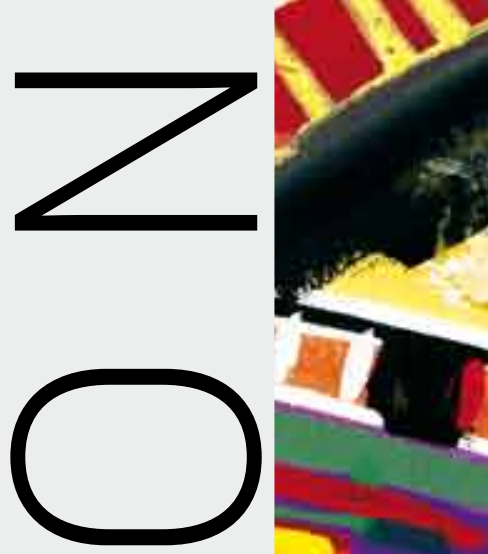

CIRAD in a nutshell

Indicators

Organization

78 
A new geographical

partnership strategy

Regional offices

Scientific platforms in

French overseas regions

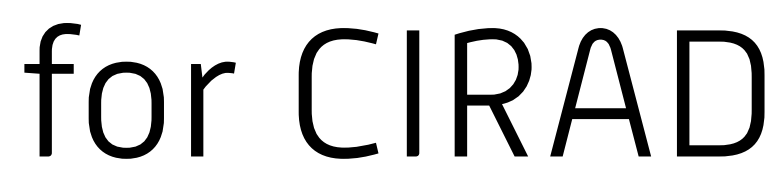

Areas covered by regional offices

Partner countries

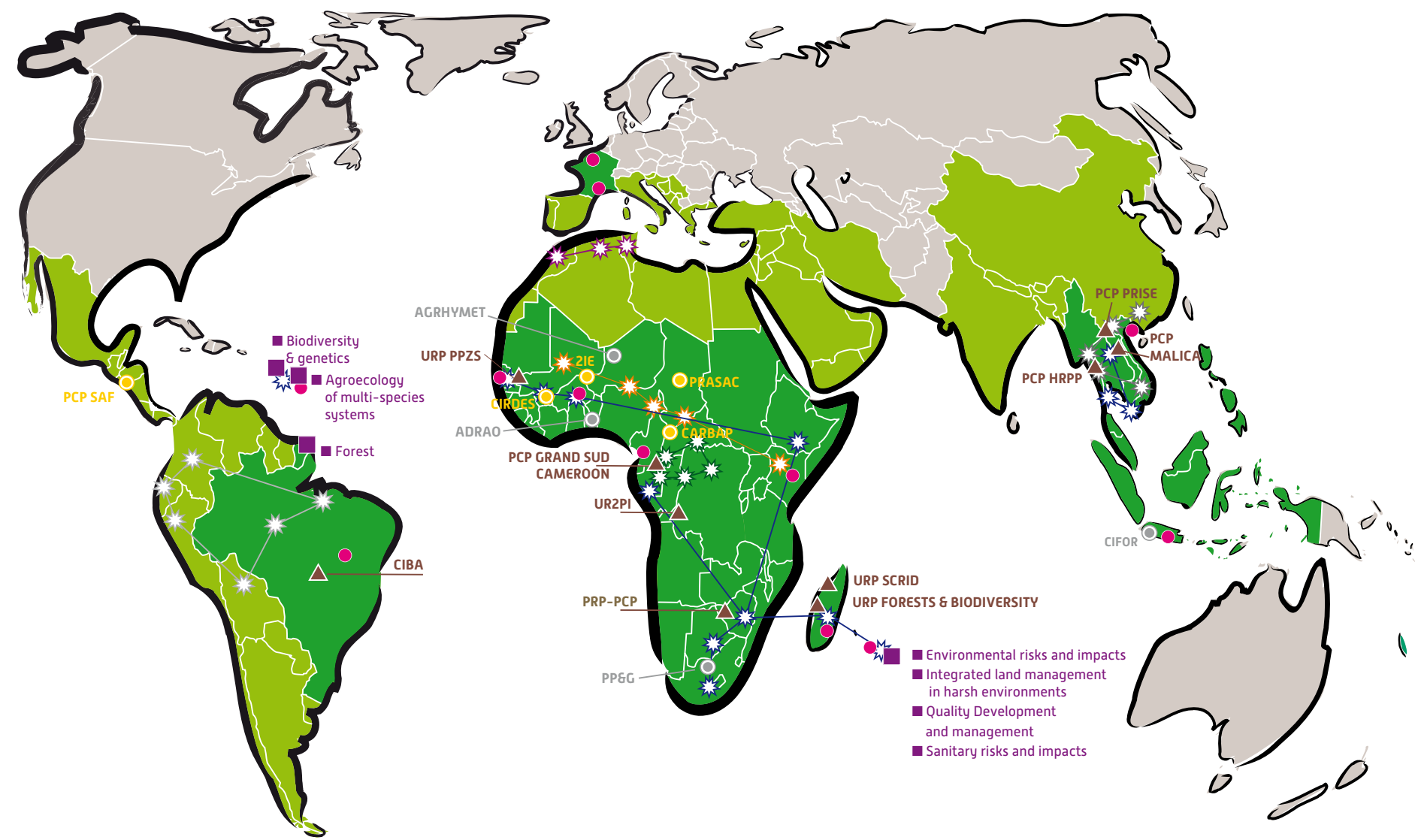

Regional and national bases

( Regional partners

$\Delta$ National bases
Thematic networks

Animal health and emerging diseases [CARIBVET, GREASE, Afrique]

Sorghum biodiversity

Forests in the Congo Basin

Water management in

the Mediterranean Basin

In grey, the platforms not yet operational in 2009

\section{Forests, agriculture and development in the Amazon}

资 Conservation agriculture in Southeast Asia 
In response to constant change in the research sector, CIRAD has pinpointed 25 research initiatives in the South that it intends to strengthen in the coming years. These initiatives centre on large-scale scientific projects, and comprise a set of dynamic research and training platforms that can be adjusted in line with the scientific topics defined by CIRAD and its partners.

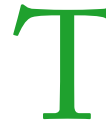
The AR4D situation, and that of international agricultural research as a whole, has changed significantly in recent years. The role of agriculture in the economic development of countries in the South is now recognized. More than ever, global issues such as emerging diseases, climate change, food security and bio-energies are headline news. Both the North and South are faced with the same research issues. AR4D and agricultural research for developed countries, particularly in Europe, are now one and the same.

\section{A real opportunity but also a greater responsibility}

On an international level, agricultural research has now carved out a place for itself, and the requests made of it bear witness to the determining role it plays in the economic development of countries in the South and in tackling global issues. The food price crisis of June 2008 and the handling of its consequences, which saw the French initiative taken up by the FAO in the form of the Global Partnership for Agriculture and Food Security (GPAFS), further strengthened its position. A commitment to rural development and to agricultural research in favour of it is part and parcel of

Contact >

Jean-Luc

Khalfaoui,

European and International Relations Service

\section{For further} information

CIRAD, 2009.

25 research initiatives in partnership worldwide: Strategies and Proposals. Paris, CIRAD, $40 \mathrm{p}$.
French, European and international policy. This was reflected in the declaration made at the G8 summit in L'Aquila, in July 2009, which confirmed that agricultural research was a priority. This change has been accompanied by the increased importance of multilateral approaches. It constitutes a real opportunity for agricultural research organizations, but also means greater responsibilities for them.

\section{Adapting to the new research situation}

CIRAD is a targeted researchfor-development organization that acts as a gateway between developing countries and the European Research Area, and its mandate is increasingly closely linked to global issues. Its know-how and its international network of partners are assets that make it a major global agricultural research player. To adapt to this new situation, CIRAD has opted to renew its geographical partnership strategy. The aim is to boost the effectiveness of its operations by focusing on the main development issues and its scientific priorities, but also by concentrating its resources in the South on research and training facilities, in partnership with the different players in the research sector. In some cases, the scale of their research is intercontinental while in others it is regional or national. In each case, the initiatives associate research organizations, universities, civil society associations (producers' groups, nongovern- firms. They also work hand-inhand with French, European and international organizations.

These initiatives are expected to play a role in the emergence of a global system, in which the activities of the CGIAR centres and research and higher education institutions in both the South and the North need to be better coordinated. This is the central issue in the debate launched at the behest of GFAR, which should result in a global and regional research agenda.

\section{Coordinating scientific priorities, partnerships and resources}

These twenty-five initiatives are to be strengthened in consultation with partners in the South. They are built on a scientific project established jointly by the partners and the CIRAD research units involved. They will make it possible to target the necessary human, technical and financial resources, and have the benefit of an on-site leader and a correspondent. They are also subject to a tailor-made set of specifications concerning assessments, an approach emphasizing quality in research and management transparency, and a road map drawn up with the partners concerned. The set of initiatives is expected to change over time, with the termination of initiatives that have achieved their goals and the emergence of new initiatives prompted by new, concerted geographical partnership operations. CIRAD is thus coordinating its scientific priorities, partnerships and resources. mental organizations), and private

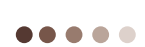

CGIAR Consultative Group on International Agricultural Research

GFAR Global Forum on Agricultural Research 
Research and education join forces to build the future

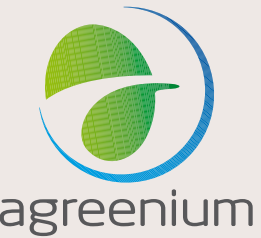

INRA, CIRAD, AgroParisTech, Agrocampus Ouest, Montpellier SupAgro and ENV Toulouse have recently set up Agreenium, the French national consortium for agriculture, food, animal health and the environment. This public scientific cooperation institution, which associates research organizations and higher education institutions, was launched in May 2009 by the Ministries of Agriculture, of Higher Education and Research, and of Foreign Affairs, proving their determination to give new impetus to the national research and training system in a sector that is of vital importance for the future.

In founding the consortium, its members wanted to make their operations more visible and apply their skills and expertise on an international level. They intend to develop and promote new agricultural, food, and resource and territorial management models for use in both the North and the South, while highlighting the challenges this represents in terms of scientific output and knowledge transmission.

The consortium is backed up by a Strategic Planning Committee open to eminent personalities from France and overseas; its operations and programmes are intended to combine research, training and development.

Contact > Jean-Luc Khalfaoui, European and International Relations Service

\section{Training and}

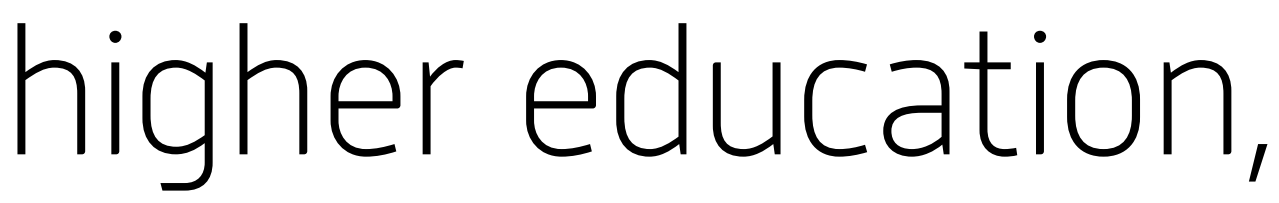

\section{an in-depth}

rethink

Strengthening PhD teaching, contributing to higher education, and participation in several Masters courses, amongst other operations: in 2009, CIRAD expanded its activities in connection with the training of students and junior researchers in France and overseas.
$\mathrm{T}$ raining, whether technical or scientific, academic or professional, is one of CIRAD's mandates. To fulfil and expand on that mandate, CIRAD has forged numerous partnerships with universities, particularly within the priority initiatives on founded. As long ago as 2008, it made a commitment to the French government to bring research and higher education closer together and boost its partnerships in this field. In 2009, this determined policy was expanded still further with the founding of Agreenium, the French national research and training consortium for agriculture, food, animal health and the environment, of which CIRAD is a founding member.

\section{PhD teaching: ensuring quality supervision}

Giving $\mathrm{PhD}$ students every chance of completing their thesis in good which its partnership strategy is
Contact >

Mireille

Mourzelas,

Higher Education and Training Service time, better dissemination of their results, helping them find their first job, and so on; through its supervision and support services, CIRAD is able to welcome students under the best possible conditions, in partnership with the $\mathrm{PhD}$ teaching structures with which its research units are associated. In 2009, CIRAD researchers supervised more than $350 \mathrm{PhD}$ students, $50 \%$ of whom came from developing countries.

\section{Supporting PhD students}

CIRAD has recently launched a training module that supports student-supervisor teams during the study process. Eighteen volunteer teams have already tested the module. The aim is both to facilitate the relationship between student and supervisor to ensure that the student makes the most of his or her abilities, and to draw up a plan of action for each team. In time, at least half the new PhD students received should benefit from this type of support. The institution has also recently seen a sharp rise in the number of directors of research on its staff. 
1000

Financial support for $\mathrm{PhD}$ students and their host teams

In 2009, CIRAD supported the work of $195 \mathrm{PhD}$ students for a total budget of $€ 700$ 000. This support fitted in with incentive operations centring on the priority lines of research outlined in its scietific strategy.

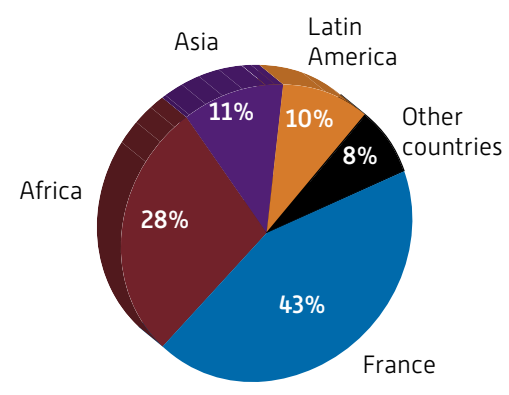

Origin of the PhD students benefiting from incentive operations

CIRAD also sets aside a share of its own resources for research grants, also centring on its priority lines of research. Thirty-nine new PhD students benefited in 2009, some of them jointly funded by the Regional Councils in Guadeloupe, Languedoc-Roussillon and Réunion, and partner organizations such as Montpellier SupAgro and INRA. More than $100 \mathrm{PhD}$ students currently receive grants.

Two Masters courses

for the booming tropical horticulture sector

\section{The HORTIMET and GEDAH} Masters courses, in which CIRAD is heavily involved, serve to train management staff from horticultural supply chains in developing countries. These supply chains are booming, yet their requirements in terms of qualified staff are far from being satisfied.

HORTIMET (Mediterranean and tropical horticulture] is a specialization under the Agronomy and Agro-food Masters offered by Montpellier SupAgro and AgroCampus Ouest. It allows students to develop a personal plan to

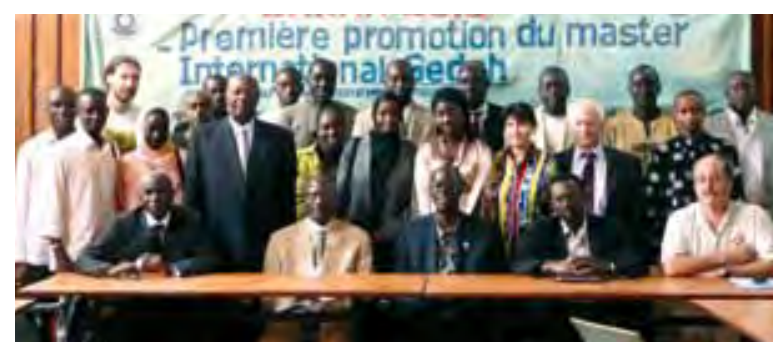

The first group for the GEDAH Masters course, with its 13 students of various nationalities (c) D. Bordat/CIRAD

improve a horticultural supply chain (varietal improvement, seed and plant production, cropping system innovations, storage and processing, or distribution], based on knowledge of how horticultural systems operate, from production to marketing, and on a systemic approach centring on cropping systems, player coordination and quality construction, for instance.

The GEDAH Masters [sustainable management of horticultural agrosystems], for its part, provides each student, regardless of the supply chain from which he or she comes, with training in how horticultural systems operate, more particularly centring on biodiversity, ecology, arthropod control, the toxicological impact of chemical inputs, host plant-pest beneficial relations, water management, pesticide residue analyses and environmental risk management. The course, which is geared towards both research and professionalization, is offered by Cheikh Anta Diop University in Dakar. the 50 CIRAD researchers assigned to universities overseas and others more directly concerned by the French higher education sector.

They are thus heavily involved in organizing Masters courses and defining their content.

Research initiatives in partnership, in Latin America, South-East Asia and Africa, play a determining role in collaboration with universities. These initiatives have forged links with French higher education institutions working with CIRAD, which has signed bilateral general agreements with nine French universities. CIRAD is involved in numerous partnerships between universities in the North and the South offering dual diplomas, joint diplomas, student exchanges, and recognition of Masters modules.

The latest e-learning technologies are often vitally important to these training operations. CIRAD has been investing in this field for several years, and offers training modules intended for various audiences, one example being training in organic matter management in developing countries.

\section{Training, an essential activity for researchers}

Numerous researchers teach at universities in France and overseas. Some are classed as teacherresearchers, consultant professors or visiting professors. They include

Racin'situ training (c) CIRAD

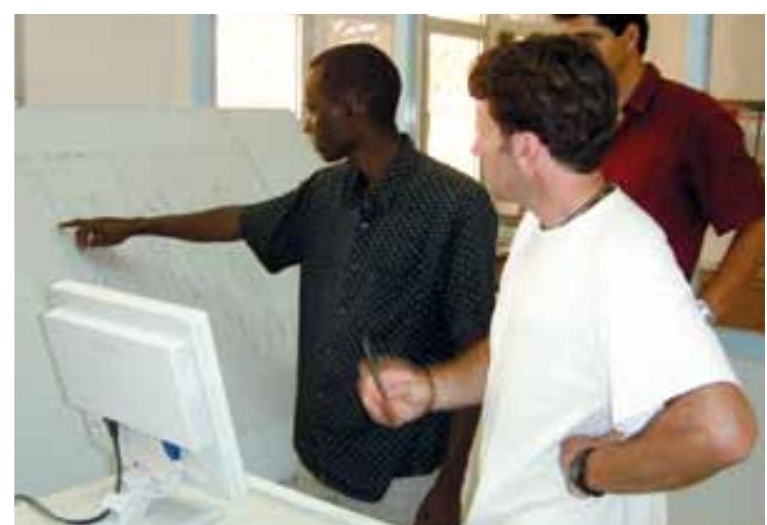

\section{0}

\section{E-learning}

This digital training module in the agronomic and environmental impact of organic matter management in developing countries makes use of dynamic tools for generating content at a distance, which makes it possible to associate researchers and teachers from CIRAD, the University of Dakar, the Institut d'économie rurale in Mali and INRA in the same course. The module is used in both Masters courses and specialist professional training courses. It is offered by the Virtual University for Environment and Sustainable Development (UVED), of which CIRAD is a founding member.

http://uved-matorg.cirad.fr $\bullet$ 


\section{CIRAD on line}

In 2009, CIRAD launched its new website. The remodelled, more user-friendly and dynamic site reflects a change in the image of the organization, which recently revised its scientific strategy and partnership approach.

The site highlights this new focus on the main global agricultural and development issues: food security, animal health, climate change, poverty alleviation, and so on. Research, teaching and training, along with innovation and expertise, which are the driving forces behind CIRAD's operations, are also more clearly visible. This is an area offering access to a whole range of documentary resources: publications, national open archive platform, scientific database, images.

The colours used, with their tropical look, echo those of CIRAD's new logo, which reflects the originality of its scientific approach and the commitment of each and every staff member to agricultural development in the South.

Contact > Anne Hébert, Communication Service

www.cirad.fr
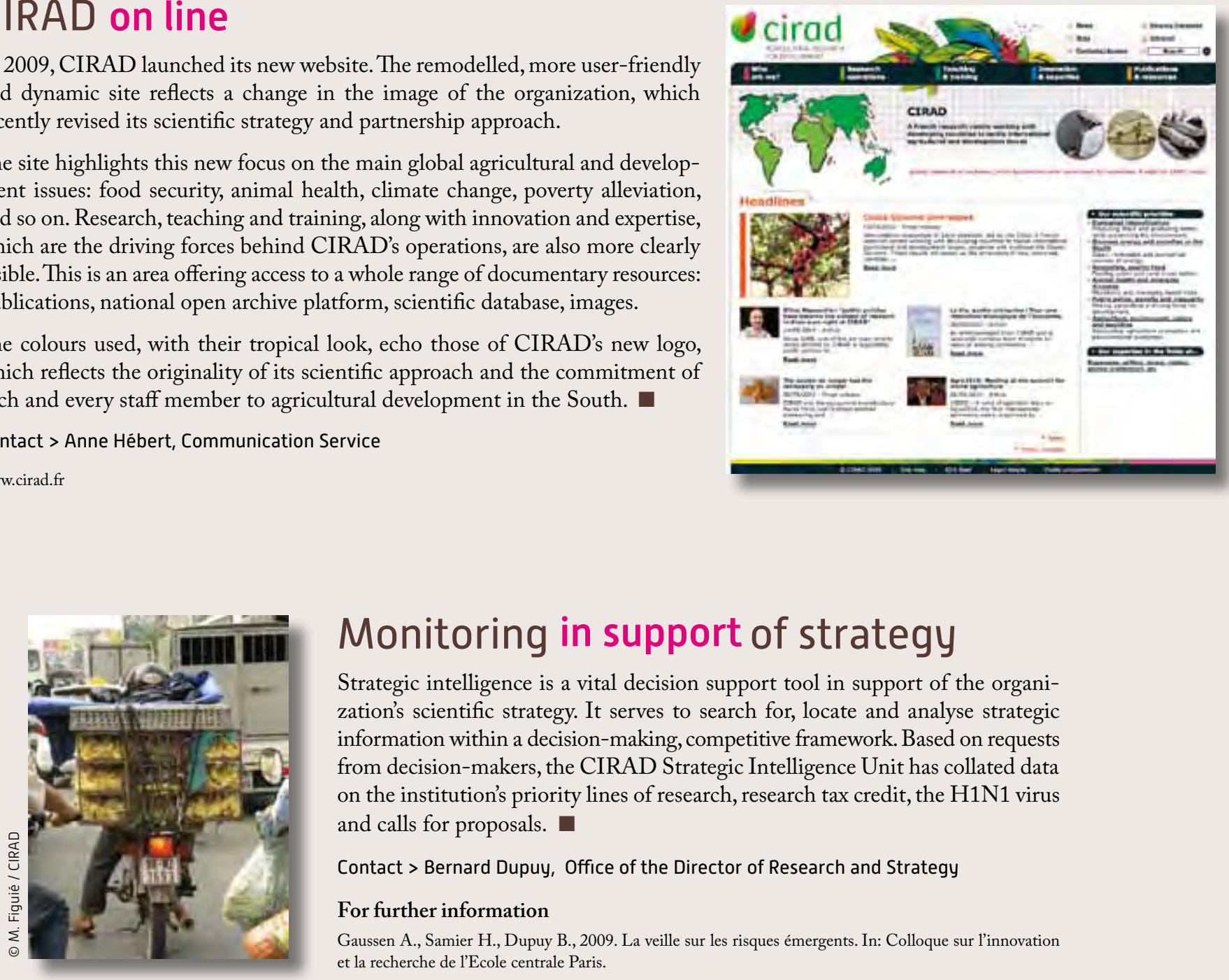

\section{Monitoring in support of strategy}

Strategic intelligence is a vital decision support tool in support of the organization's scientific strategy. It serves to search for, locate and analyse strategic information within a decision-making, competitive framework. Based on requests from decision-makers, the CIRAD Strategic Intelligence Unit has collated data on the institution's priority lines of research, research tax credit, the H1N1 virus and calls for proposals.

Contact > Bernard Dupuy, Office of the Director of Research and Strategy

\section{For further information}

Gaussen A., Samier H., Dupuy B., 2009. La veille sur les risques émergents. In: Colloque sur l'innovation et la recherche de l'Ecole centrale Paris.

\section{An information network and a platform on the world's plants}

Knowing the identity, geographical distribution, uses and production of plants is essential to agricultural development and biodiversity management. However, this information is generally difficult to find, or sketchy in the case of the ecosystems that house the greatest degree of plant diversity: those in tropical and Mediterranean regions. The P1@ntnet project's main objective was to compile and exchange the information on the world's plants held by a range of communities, both scientific and non-scientific. This ambitious project, headed by CIRAD, INRA, INRIA and IRD, ran for four years with financial support from the Agropolis Fondation.

Contact > Daniel Barthélémy, Botany and Computational Plant Architecture [AMAP], contact@plantnet-project.org

\section{For further information}

www.pl@ntnet-project.org

Barthélémy D. et al., 2009. The P1@ntnet project: plant computational identification \& collaborative information system. In: International Conference on Biodiversity Informatics, London, United Kingdom, 1-3 June 2009.

\section{PARTNERS}

Africa Rice Center, Institut de recherche pour le développement (IRD), Institut français de la vigne et du vin (IFV), French Institute of Pondicherry, Institut national de la recherche agronomique (INRA), International Rice Research Institute (IRRI), Kruger National Park (South Africa), Tela Botanica, Institut national de recherche en informatique et automatique (INRIA), International Union for the Conservation of Nature (IUCN), Central University of Venezuela, University of California Davis (United States), Agropolis Fondation
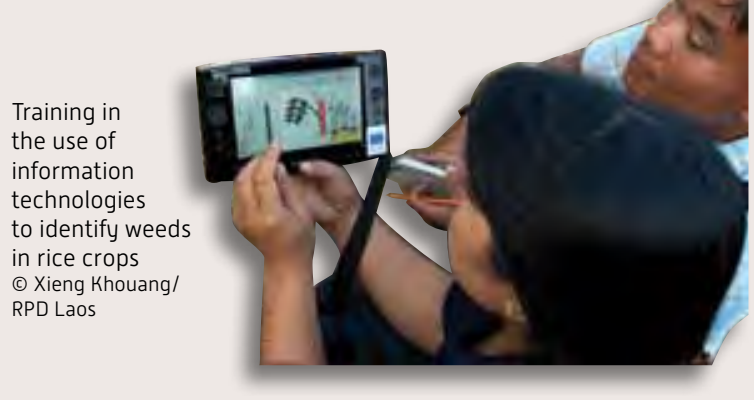
A set of references

\section{for quality in research}

Within the framework of its scientific strategy and in line with its contractual objectives entered into with the State, CIRAD recently established its third three-year plan (2009-2011) to promote quality in research. It has thus embarked upon an overall approach aimed at ensuring progress through process-based methods, with a view to gradually involving all the institution's staff and activities, in a pragmatic way.

$\mathrm{T}$ he 2009-2011 plan has four objectives: to confirm the improvement in quality within the institution; to consolidate the structure of its quality services; to coordinate operations; and to assess the results so as to boost the performance of the approach. The quality policy and the organizational structure need to enhance the institution's reliability and its legitimacy in the eyes of its supervisory ministries, donors, clients and partners; generally speaking, they help to improve exchanges, both internal and external. CIRAD has thus set itself three priority objectives: to improve the traceability of research and management processes, guarantee the reliability of its results and information, and make its results and products more easily available.

The quality approach is clearly displayed as one of the institution's priorities, with clear objectives that receive human, financial and technical support. It involves the highest levels of management, and is due to be backed up by appropriate communication and support training for CIRAD's different teams. It favours a structure centring on projects, and refers to Afnor's ${ }^{1}$ recommendations on quality in research and working via projects within a network. Operations are launched on a whole-

1. The French standards authority organization scale, but also on the scale of its different components. In every case, they require both skills and funding.

The Quality Service has established an overall approach that guarantees the coherence of the initiatives taken. It facilitates operations by making approaches, tools and documents universally available. It has just drawn up a summary map of the main common processes at work within CIRAD and a new set of references inspired by ISO standard 9001, which will be available to the components that adopt the approach. At the end of the three-year plan, half CIRAD's constituent parts should have reached level 3 on the CIRAD quality assessment scale, which has five levels (level 5 corresponds to certification or accreditation by a third party).

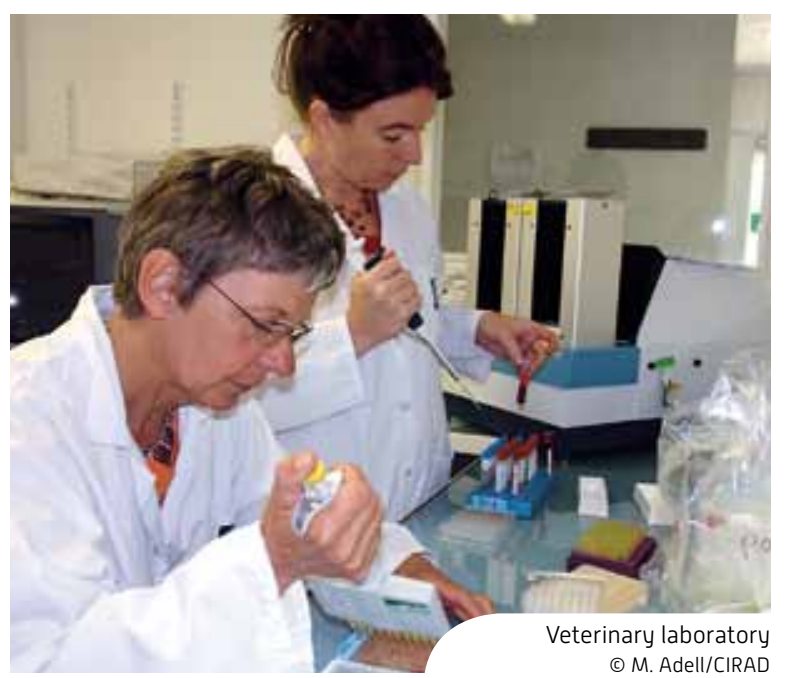

Contact >

Léandre Mas, Quality Service

\section{For further} information

Granier C. et al., 2009. La démarche qualité dans la recherche publique et l'enseignement supérieur. Paris, Quæ, 376 p. conserving agrobiodiversity in Montpellier

In October 2009, CIRAD, INRA, IRD and Montpellier SupAgro launched a major federative project for the study and conservation of agrobiodiversity: ARCAD. The aim was to analyse the evolutionary history, domestication and adaptation of Mediterranean and tropical crops so as to make better use of and conserve their genetic diversity. The project includes studies of the comparative phylogenomics of the crops and their wild ancestors, how plants adapt to climate change, and the diversity and dynamics of cereal evolution in Africa. It also involves backup research for data processing, association genetics, genetic resources cryopreservation, DNA bank management, and the organization of training. Several CIRAD teams and technical platforms are involved in work relating to genomics, population genetics, bio-informatics and anthropology. In the medium term, there are plans for a building to house genetic resources and for training courses, along with a genotyping and sequencing platform. This Agropolis Fondation project is due to include other French and foreign partners, such as CNRS, universities, national agricultural research services and CGIAR centres.

Arcad Agropolis Resource Center for Crop Conservation, Adaptation, and Diversity

www.arcad-project.org

Contact > Jean-Pierre Labouisse, Plant Development and Genetic Improvement (DAP)

\section{PARTNERS}

Institut national de la recherche agronomique (INRA), Institut de recherche pour le développement (IRD), Montpellier SupAgro, Languedoc-Roussillon Regional Council 


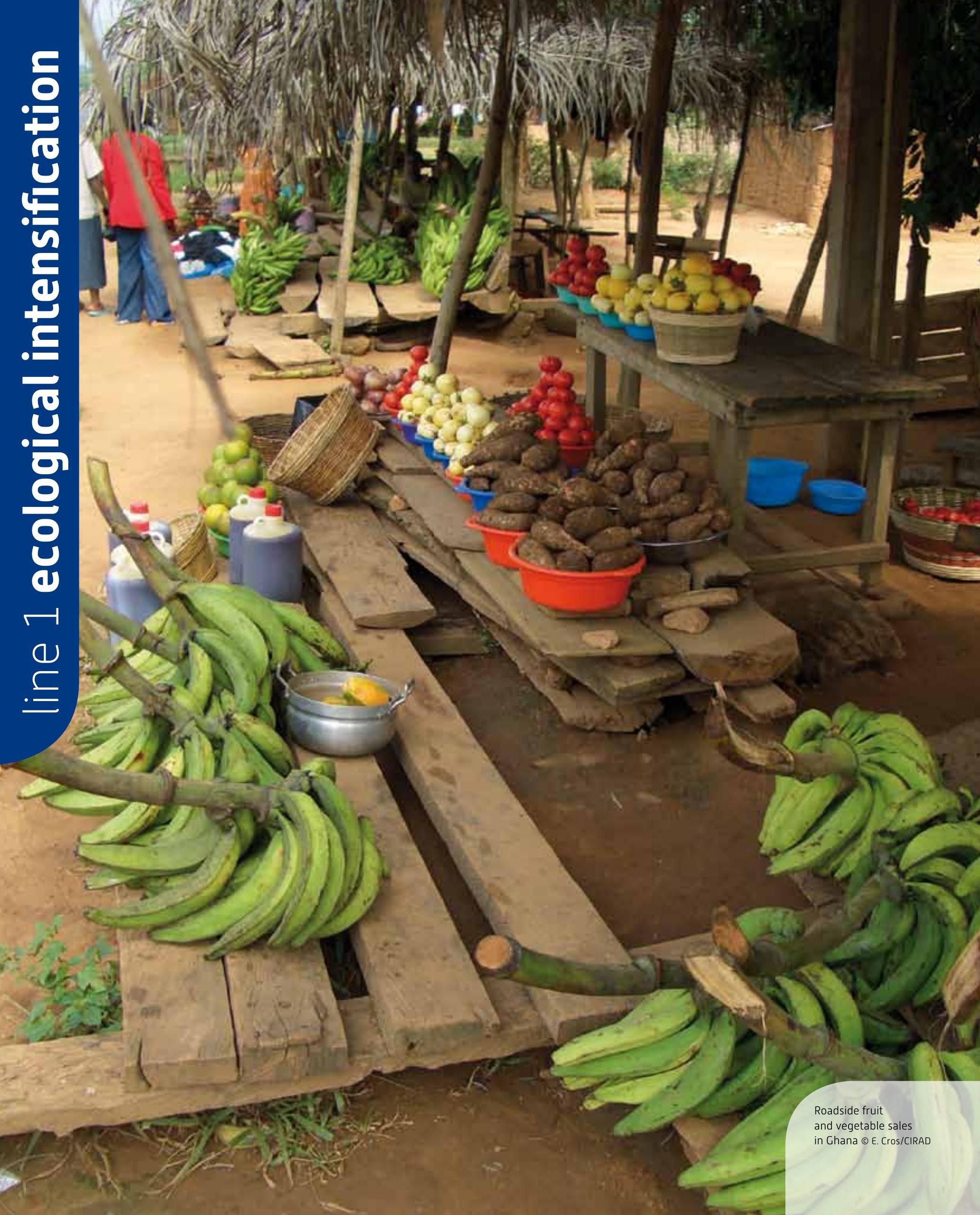


Citrus root stocks

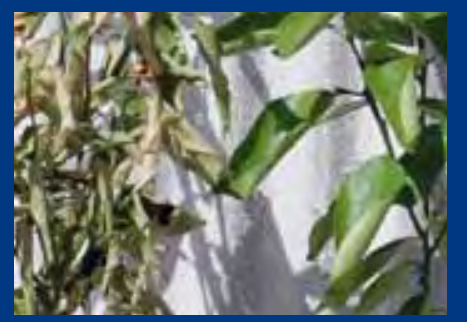

Sorghum genetic diversity

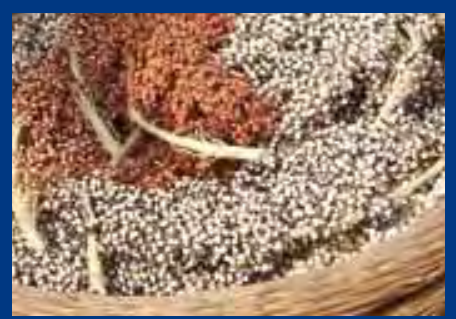

page 22

\section{Sustainable}

\section{agriculture}

Developing sustainable, lowinput and environmentally safer, yet more productive, farming systems is a major challenge that CIRAD aims to meet. It forms the basis of CIRAD's partnerships in almost all of its priority research structures located in French overseas regions and elsewhere worldwide.

\section{Climate change}

CIRAD is closely involved in research on climate change issues. A file entitled "Changement climatique et agriculture: l'environnement et la sécurité alimentaire en jeu", which can be downloaded from the CIRAD website, is a set of fact sheets presenting projects with which CIRAD is involved. In conjunction with the Copenhagen Climate Summit, the

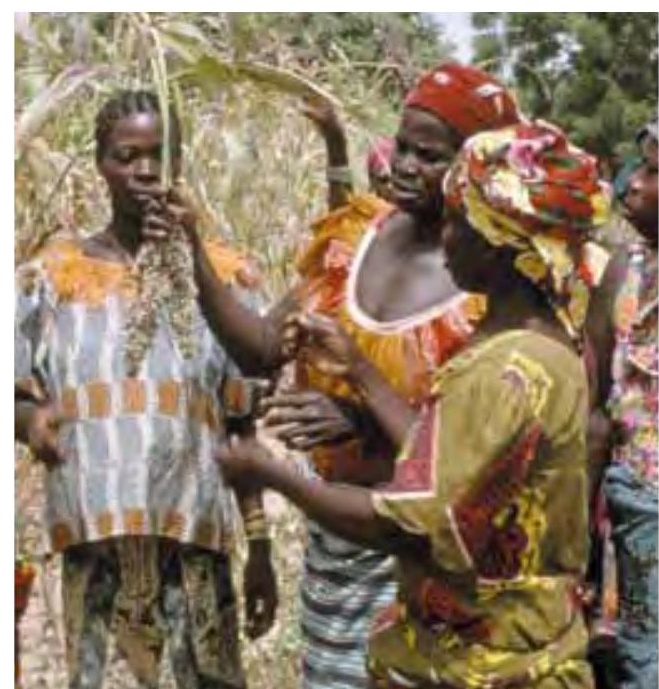

crop protection networks on different continents.

Environmental concerns and local know-how must be taken into consideration in crop improvement programmes in order to facilitate the management and effective use of biodiversity and enhance the sustainability of crop production under changing climatic conditions. A very large research unit is being formed that pools teams from many Montpellier-based research institutions. Genomics combined with studies on plant adaptation capacities, as well as biological resource centres are the focus of far-reaching programmes under way in collaboration with many partners. In 2009, CIRAD hosted a workshop on hevea genome and transcriptome. case study on bananas, and recommendations were subsequently drawn up to guide farmers in reducing pesticide use in banana plantations. This study also strengthened ties between scientists in EU ultra-peripheral regions and CARBAP, Cameroon, and more broadly between

Women farmers in a sorghum field Burkina Faso (๑) J. Chantereau/CIRAD

\section{Cell imaging}

Since 2002, CIRAD's Histology and Plant Cell Imaging Platform (located on the Lavalette campus, Montpellier) fulfils the needs of life science researchers. The platform is specialized in histocytological and cell imaging research as part of, and in compliance with the philosophy of, the Montpellier Rio Imaging (MRI) regional platform. It has just received the label of INRA's Commission nationale des outils collectifs (CNOC), thereby becoming a collective research tool (OCR) as part of a package of hightech equipment available to partners from other French research institutions and developing countries.

\section{Training}

Finally, in this area, CIRAD is engaged in an ever-increasing number of partnerships with universities, which take various forms. It is involved in Master's programmes, e.g. HortiMet (Mediterranean and Tropical Horticulture) with Montpellier SupAgro and Agrocampus Ouest, and GEDAH (Sustainable Horticultural Agroecosystem Management) with Cheikh Anta Diop University, Senegal. It participates in joint initiatives to strengthen scientific expertise, including the SudBiotech project with the University of Paris 11 and CNRS, which was set up to build a permanent NorthSouth biotechnology training network. CIRAD is also developing e-learning modules within the framework of the Virtual University for Environment and Sustainable Development (UVED). In 2009, several agricultural extension agents in Martinique and teacher-researchers and $\mathrm{PhD}$ students in Senegal thus took the module on "Agricultural and environmental impact of organic material management in tropical environments". 


\section{The Banana streak virus: an extreme case of parasitism}

\begin{tabular}{|l} 
The genomes of many plants harbour virus \\
DNA fragments that are relics of ancient \\
infections. A major problem in banana \\
production is that the banana genome contains \\
vestiges of the banana streak virus. \\
A CIRAD team determined the sequence \\
structure of the virus species most frequently \\
noted during epidemics so as to gain insight \\
into their integration and activation \\
mechanisms. The results should be bighly \\
beneficial for banana breeding programmes.
\end{tabular}

Tn recent years, analysis of a $\perp_{\text {large number of plant genomes }}$ revealed that they had been massively invaded by a broad range of viral sequences. These turned out to be DNA viruses belonging to five of the six genera that make up the Caulimoviridae family. These viral integrations are "illegitimate" since the integration process is not part of the virus propagation cycle. Their presence could either have no effects on the plant, or benefit the plant by providing it with resistance to related viruses, or induce infections when the complete genome of the virus is present. In the latter situation, stress-activated insertion can lead to infectious virions.
Integrations capable of restoring a functional viral genome

The banana genome has been altered by very many integrations of this type, which correspond to several Banana streak virus (BSV) species. These integrations, denoted eBSV, are variable in terms of sequence, copy number been frequent and recent and primarily concern the Eumusa section, which encompasses most banana species that are grown for their fruit. At least 27 independent integration events were noted in three banana species: Musa acuminata, $M$. schizocarpa and M. balbisiana. However, only inteand structure. They seem to have

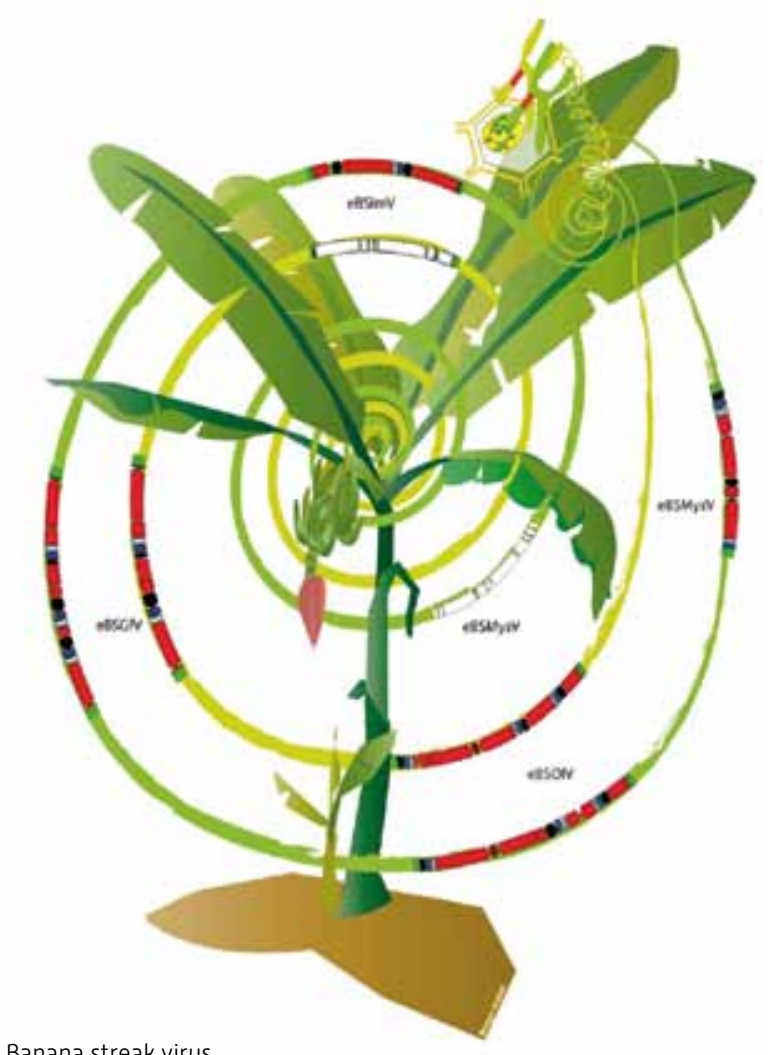

Banana streak virus insertions in Musa balbisiana PKW (c) S. Galzi/CIRAD

grations in the $M$. balbisiana genome (B genome) are infectious - they are capable of restoring a functional viral genome that, like free viruses, can contribute to propagation of the disease.

The $\mathrm{B}$ genome is closely related to plantain (AAB), a staple food for millions of people in Africa, Latin America and the West Indies. Plantain is also used in banana breeding programmes. For all of these reasons, BSV has become a major handicap to the banana industry. 


\section{Analysing viral insertion integration and activation mechanisms}

In order to gain insight into eBSV sequence integration and activation mechanisms, a CIRAD research team studied the sequence structure of the four BSV species most commonly identified during epidemics: Goldfinger-BSGfV, Imové-BSImV, Mysore-BSMysV and Obino l'Ewai-BSOLV. M. balbisiana $\mathrm{PKW}$ was used as the host banana species in this study, since it is known to be a healthy carrier and resistant to the propagation of any viruses that are free-living or integrated in its genome. This banana species, which is used as female parent in interspecific crosses, is solely responsible for the transmission of eBSV sequences in the F1 progeny, three of which cause infection.

The structural organization of eBSV species was analysed using libraries of large genomic DNA fragments containing various integration profiles. The entire eBSGfV integration pattern was determined and found to contain two complex structures: eBSGfV-7 and eBSGfV-9. The genotyping and segregation analysis findings revealed that eBSGfV resulted from a single integration event and forms two alleles at the same locus in the M. balbisiana PKW genome, with only the eBSGFV-7 allele being infectious. eBSImV and eBSOLV integrations were also
PARTNERS

Génoscope (France), Julius Kühn-Institut (JKI, Germany), National Institute of Agrobiological Sciences (Japan), Région

Languedoc-

Roussillon (France), European Union,

University of Basel (Switzerland), University of Frankfurt (Germany), University of Minnesota (USA) found to have an insertion at a single locus, i.e. monoallelic and diallelic, respectively. The analysis of eBSMysV is under way and has already been found to have two different insertions from two independent events.

Genotypic markers were developed and molecular signatures determined for each of these alleles. This provides geneticists with infectious eBSV specific markers to use in their banana breeding programmes.

Contacts >

Marie-Line Iskra-Caruana,

Matthieu Chabannes, Biology and

Genetics of Plant-Pathogen Interactions [UMR BGPI],

Franck-Christophe Baurens, Plant Development and Cenetic Improvement [UMR DAP]

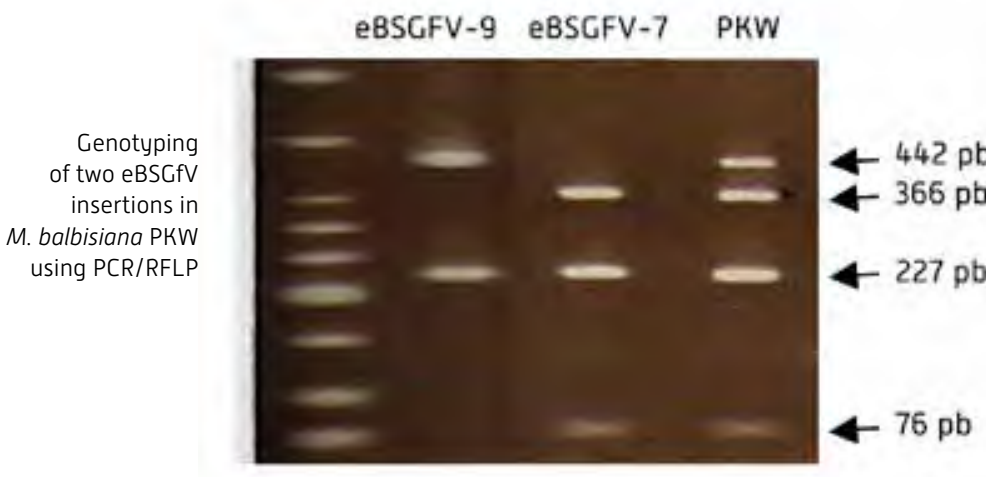

BSV

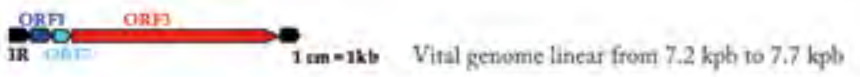

\begin{tabular}{|l|l|l|l}
\hline eBSGFV-7 \\
eBSGFV-9
\end{tabular}

\section{FORFURTHERINFORMATION}

Cote F.X. et al., 2010. Micropropagation by tissue culture triggers differential expression of endogenous Banana streak virus (eBSV) in the B genome of natural and synthetic interspecific banana plantain. Molecular Plant Pathology, 11: 137-144.

Gayral P., Iskra-Caruana M.L., 2009. Phylogeny of Banana streak virus reveals recent and repetitive endogenization in the genome of its banana host (Musa sp.). Journal of Molecular Evolution, 69: 65-80.

Staginnus C. et al., 2009. Suggestions for a nomenclature of endogenous pararetroviral sequences in plants. Archives of Virology, 154: 1189-1193. 


\section{Understanding banana \\ domestication: a crucial step}

\section{towards improvement}

Geneticists, geographers, archaeologists and linguists collaborated to trace the history of bananas. They revealed how, via human migration, isolated primitive fertile forms growing in South-East Asia evolved into sterile triploid forms, which account for most of the dessert bananas and plantains produced nowadays. These findings open new avenues for banana breeding.

Darthenocarpy, i.e. seedless fruit 1 pulp development, is a major factor in banana domestication. The resulting sterility is offset by vegetative propagation. This feature first appeared in diploid forms in South-East Asia, and then became widespread in triploid cultivars, which account for most banana production. The cultivated subgroups combine genomes of Musa acuminata (denoted A) and M. balbisiana (B): dessert bananas (AAA), Mutika from East Africa (AAA), plantains from Africa and the Pacific region (AAB), Pome and other subgroups from India ( $A A B$ and $A B B)$. Improved varieties are essential in all of these regions to overcome problems of disease development, pesticide treatment restrictions and environmental degradation. These varieties must be adapted to local conditions and be in line with the taste, culinary and technological qualities of the different cultivars.

Sterility is still a major constraint to improvement, which is inevitably based on hybridization between fertile forms in breeding schemes

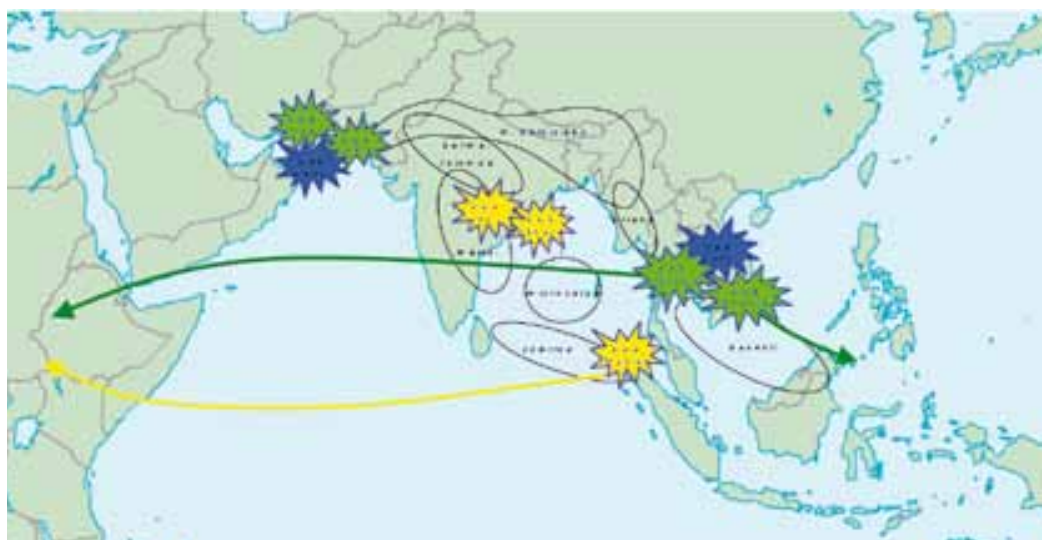

Zones in which the main triploid subgroups formed. In black: distribution ranges of M. balbisiana and the main wild M. acuminata subspecies that are always very short. To replicate the traits of cultivated triploid bananas, the parent stock must be close to the original diploid parents. A clear understanding of phylogenetic organization of the diversity is thus essential.

Migrations, exchanges and
evolutionary processes

CIRAD has a collection of over 500 genotypes in Guadeloupe. SSR and DArT molecular marker analyses were recently carried out to complete the characterization (morphological, biological, genetic, etc.) of these accessions. The overall results highlighted key events in the process of evolution from wild forms to triploids via cultivated diploids.

Musa diversity is based on the preliminary differentiation of $M$. acuminata into subspecies through geographical isolation in SouthEast Asia: banksii in Papua New Guinea, zebrina in Java, errans in 
A dessert banana breeding platform in the West Indies

CIRAD has set up a breeding platgenetic improvement programme in Guadeloupe. The aim is to obtain 1500 banana hybrids yearly and to develop ultimately one or two new varieties that will be validated by banana growers. These hybrid varieties must meet West Indian banana production and European market requirements (sigatoka disease resistance, fruit quality, etc.) and will be geared towards diversification. The West Indian banana production industry is directly associated with the platform, especially for the breeding and validation of hybrid varieties. Beyond the French West Indies, the new hybrids will be included in a Caribbean regional cooperation programme, while also being offered to farmers in non-competitive banana growing areas in French overseas regions. This is the only hybrid banana production platform worldwide. It is part of the "Sustainable banana production plan for Guadeloupe and Martinique", which aims to promote innovations for the development of sustainable cropping systems.

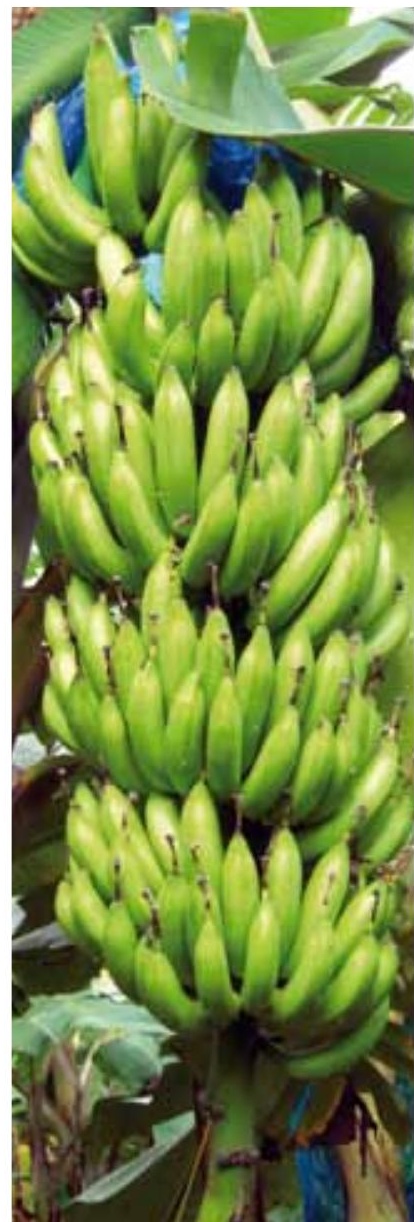

France), Union

\section{Contact >}

Jean-Pierre Horry, Genetic Improvement of Vegetatively Propagated Crops [UPR] form to intensify its dessert banana

and viral emergence: a begomovirus model

Begomoviruses are responsible for several emerging diseases that have an economic impact on crops. Their genetic diversity is especially high in Africa and on Indian Ocean islands. A CIRAD team investigated evolutionary factors associated with this diversity and has just revealed that the adaptation capacity of these viruses is correlated with their recombination potential and high mutation rates. banane (ITBAN,

France), Office

de développement

de l'économie

agricole d'outre-mer

(ODEADOM,

des producteurs

de banane de

Guadeloupe et

de Martinique (UGPBAN, France)

Flhorban 925, a hybrid banana variety

PARTNERS Fund for Rural Development (EAFRD), Institut

\section{A} mong plant viruses, those belonging to the Begomovirus genus, which have singlestranded circular DNA genomes and are transmitted by Bemisia tabaci whiteflies, cause several serious emerging crop diseases. Their genetic diversity is especially high in Africa and on islands in the south-western Indian Ocean region. The virus forms that prevail on these islands belong to the African-Mediterranean group of monopartite (a single DNA molecule) and bipartite (two DNA molecules) begomoviruses, as confirmed by phylogenetic reconstruction findings, and they are of polyphyletic origin, i.e. they have no common direct ancestor.

A study of evolutionary factors associated with the genesis of this diversity showed that recombination has had a major impact on the evolution of these viruses. The results also revealed sites that are conducive (hot spots) or not conducive (cold spots) to recombination on their genome. The findings of an overall assessment of begomovirus sequences available in databases suggested that mechanistic and selective factors were involved in shaping the recombination patterns. Mechanistic hypotheses concerning conflicts between replication and transcription complexes could explain how recombinants have been generated. A study of levels of protein disruption following recombination demonstrated that recombinants, once created, are under high purifying selection pressure, which acts on deleterious rearrangements. Ultimately, only virus recombinants for which recombination has not disturbed the biological functions should remain.

This analysis, which was extended to all single-stranded circular DNA viruses, again highlighted that, despite a very diverse range of

Dwarf cassava plant affected by cassava mosaic disease (CMD), Madagascar (c) J.M. Lett/CIRAD

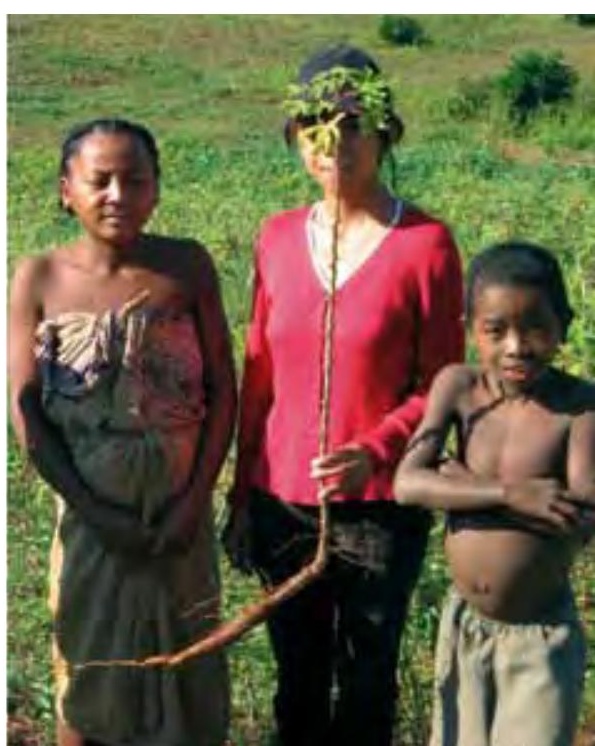




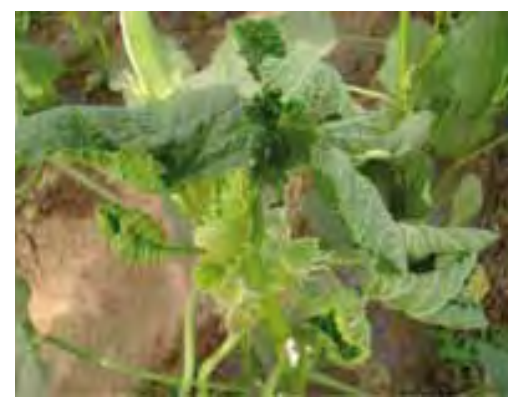

Symptoms of okra leaf curl disease [OLCD], Burkina Faso ๑ F. Tiendrébéogo

hosts (animals, plants and bacteria), purifying selection is crucial in shaping recombination patterns.

The ability of begomoviruses to exchange genetic material by recombination, along with their high mutation rates, seem to be strong assets that enable them to adapt to new ecological niches generated by the global dissemination of crop species and invasive biotypes of their insect vectors. These viruses-because of all of these epidemiological parameters-are serious contenders for emergence.

Contacts > Jean-Michel Lett, Bernard Reynaud, Plant Communities and Biological Invaders in Tropical Environments (UMR PVBMT)

\section{PARTNERS}

European Regional Development Fund (ERDF), French wMinistries of Foreign Affairs, Research and of Overseas France, University of Abidjan (Côte d'Ivoire), University of Antananarivo (Madagascar), University of Bangui (Central African Republic), University of Canterbury (New Zealand), University of Cape Town (South Africa), University of Ouagadougou (Burkina Faso)

\section{FORFURTHERINFORMATION}

Lefeuvre P. et al., 2009. Widely conserved recombination amongst single stranded DNA viruses. Journal of Virology, 83: 2697-2707.

Lett J.M. et al., 2009. Complete genomic sequences of Tomato yellow leaf curl Mali virus isolates infecting tomato and pepper from the north Province of Cameroon. Archives of Virology, 154: 535-540.

Varsani A. et al., 2008. Recombination, decreased host specificity and increased mobility may have driven the emergence of Maize streak virus as an agricultural pathogen. Journal of Genetics and Virology, 89: 2063-74.

New citrus

\section{rootstocks for the}

Mediterranean Basin

Around 20\% of all citrus fruits produced worldwide come from the Mediterranean Basin region. The citrus crops are irrigated, but water shortages are common and salt water is often used for irrigation. CIRAD, in partnership with IVLA in Spain, conducted a study to assess the tolerance of new citrus rootstocks with respect to these constraints. This programme should lead to the development of cultivars better adapted to coping with the climate change that is forecasted for the region.

$\mathrm{Oi}_{\mathrm{i}}$ trus fruits are grown under irrigated conditions throughout the Mediterranean region, but water shortages are common and salt water is often used for irrigation. A major challenge for citrus growing is thus to develop rootstocks that are more tolerant with respect to these constraints. CIRAD, in partnership with IVIA in Spain, conducted a study to assess the tolerance of new tetraploid citrus rootstocks.

One feature of citrus rootstocks is that they can spontaneously produce tetraploid genotypes via the doubling of chromosome numbers in diploid seeds. The chromosome doubling frequency is very high for some rootstocks. Hence, $5-10 \%$ of the rootstocks are tetraploid in Spanish orchards where citrus has been grafted on Carrizo citrange. This situation has long been known, but few studies have focused on the agricultural potential of these citrus tetraploids.

\section{Marked physiological differences between diploids and tetraploids}

The physiology, morphology and anatomy of tetraploid genotypes differ substantially from those of the diploid parents. They have a lower growth rate due to higher regulation of respiratory exchange
PARTNERS

Domaine Kabbage (Morocco), Institut national agronomique de Tunis (Tunisia), Institut national de la recherche agronomique (INRA, France), Instituto Valenciano de Investigaciones Agrarias (IVIA,

Spain), Ministry of Science and Innovation (Spain) 
through leaf stomata. They have larger seeds, thicker dark green leaves, shorter stem internodes, and stockier secondary roots. Moreover, they have larger cells than diploids.

These plants have much greater stress tolerance than diploids, like diploid varieties that have been grafted on tetraploid rootstocks, e.g. cv Valencia orange. However, in both cases, the stress seems to be perceived at the same time, leading to concomitant stoma closure.

Under salt stress conditions, the respiratory exchange regulation noted in tetraploid genotypes is also responsible for reducing chloride and sodium ion uptake in roots. Transfer of these toxic ions to the leaves via the transpiration stream is reduced, thus making these tetraploid genotypes salt stress tolerant.

\section{Abscisic acid has a key role in stress tolerance}

In water stress conditions, stoma opening is primarily controlled by abscisic acid (ABA) synthesis in the roots. This hormone is then conveyed through sap flow to the stomata, where it triggers their closure. In the absence of stress, root ABA synthesis is greater in tetraploid rootstocks than in diploids. These results were confirmed in studies on diploid and tetraploid genome expression in roots.

Acute ABA production in tetraploids was found to lead to reduced gas exchange (transpired water and absorbed $\mathrm{CO}_{2}$ ) and could explain the greater water stress tolerance of these plants. This constitutive capacity of tetraploid rootstocks enhances the resistance of rootstock-scion citrus trees to water shortages. It is also responsible for the lower growth rate of these plants and their higher salt stress tolerance.

\section{Rootstocks to preserve water resources}

Almost $60 \%$ of the water resources of North Africa are used for agriculture. Tetraploid rootstocks help preserve water resources by reducing the water requirements of citrus varieties. Citrus trees have recently been planted at Elche, Spain, under stressful soil-climate conditions, combining drought, salinity and chalky soils. In addition to tolerance to such abiotic stresses, the yields of these growthinhibited trees will be monitored. This feature is not necessarily a disadvantage-planting smaller trees with lower water needs in denser stands could be an asset for orchard management. A study carried out in collaboration with
INRA in Corsica also revealed that high quality clementines could be produced on tetraploid rootstocks. CIRAD intends to make effective use of these results by developing new tetraploid hybrids that combine abiotic stress tolerance and disease resistance.

Contact > Raphael Morillon, Genetic

Improvement of Vegetatively

Propagated Crops (UPR]

\section{FORFURTHERINFORMATION}

Allario T, 2009. Identification de déterminants physiologiques et moléculaires de la tolérance à la contrainte saline et au déficit hydrique de portegreffes autotétraploïdes d'agrumes. $\mathrm{PhD}$ thesis, $335 \mathrm{p}$

Allario T. et al., 2009. Autotetraploid Citrus limonia rootstocks are more tolerant to water deficit than parental diploids. In: International Conference on Polyploidy, Hybridization and Biodiversity, 17-20 May 2009, Saint-Malo, France.

Morillon R. et al., 2009. Tetraploidy and tolerance to environmental stresses in citrus. In: International Conference on Plant Abiotic Stress Tolerance, 8-11 February 2009, Vienna, Austria.

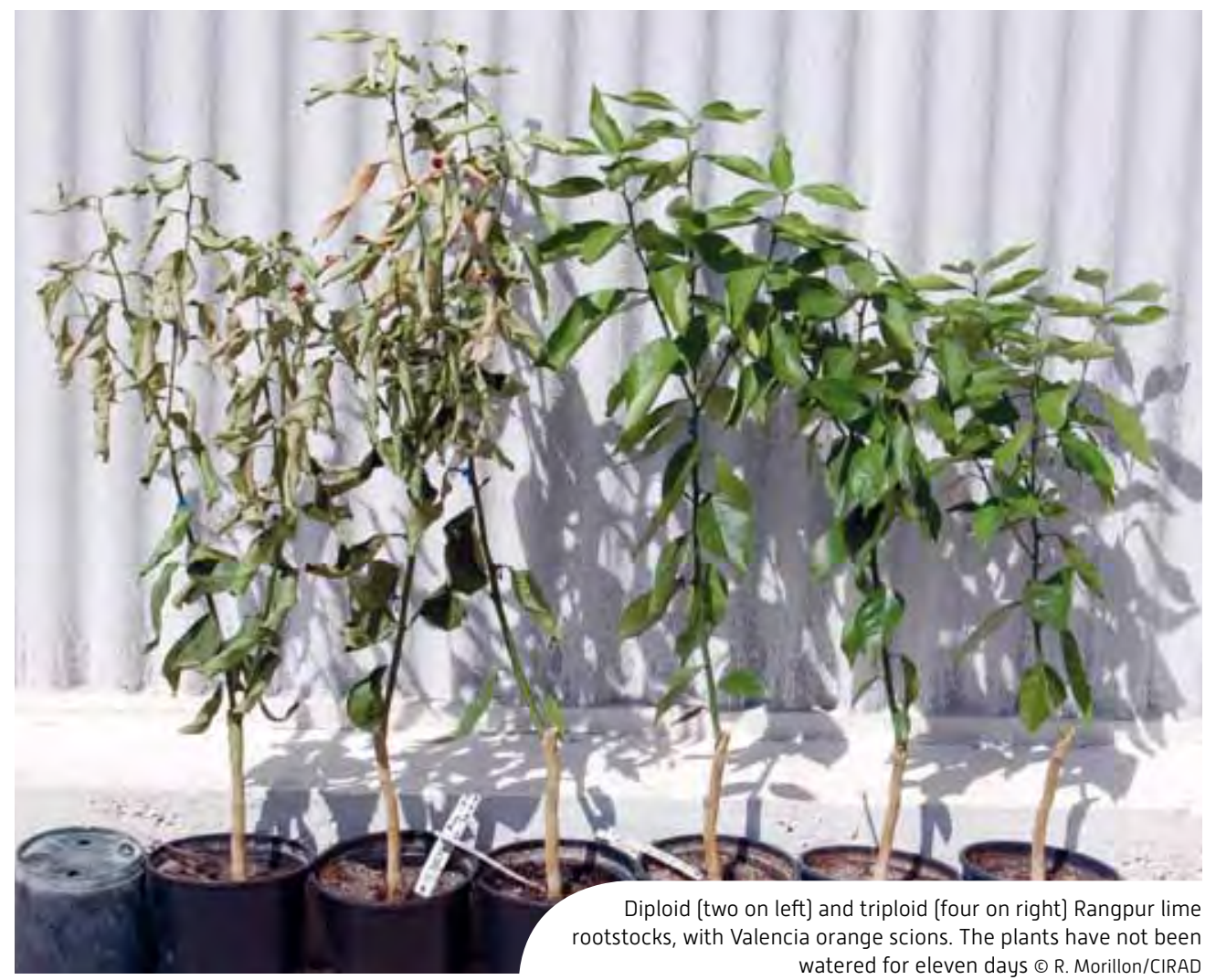




\section{The first coffee DNA microarray}

Coffee is a product of mass consumption, with worldwide consumption estimated at over 2.2 billion cups a day. Coffee improvement is thus a major challenge. The aim is to tailor this native African species to global intertropical cropping conditions. CIRAD and its partners have just developed the first coffee DNA microarray, PuceCafe, to enhance control of its adaptation capacities and streamline coffee breeding. It will facilitate studies on coffee gene expression under a range of conditions.

A DNA microarray is a set of ADNA molecules attached to a glass slide-it can be used to analyse gene expression in tissues under various conditions. It provides the global signature of analysed tissues and can determine the state (diseased tissue), time (fruit development) or environment (temperature). PuceCafé, a microarray that has recently been developed for coffee, contains 15000 DNA strands, each of which is specific to a gene. The first series was produced at the GenomiX platform in Montpellier (France) and then validated.

This DNA chip has been used to study the adaptation capacity of Arabica (Coffea arabica) coffee trees to climatic changes in regulated chambers to control the cropping conditions. An analysis compared the behaviour of this species cultivated in tropical highland regions with that of two related species, i.e. C. canephora (Robusta), which is adapted to growing under hot climatic conditions in tropical forests, and $C$. engenioides, a wild species that is adapted to cooler highland conditions in Africa. The behaviour of Arabica under the hottest conditions was close to that of Robusta coffee trees, and under the coldest conditions it was midway between the two species. The genes involved in this behaviour were identified. The functional plasticity of Arabica will be studied using these microarrays under temperature conditions close to those that climatologists are forecasting for the near future.

Genes involved in seed desiccation and germination were also identified. The results, combined with hormonal data, revealed that coffee beans have unique features as compared to other seed types. A study of coffee berry development also highlighted the involvement of known genes and others with unknown functions. An analysis of drought resistance genes is currently under way.

PuceCafé is an efficient tool that provides a massive comprehensive image of coffee genome expression. It is estimated that, with over 15000 genes, half of the coffee transcriptome could be studied. Results already obtained with this tool have been published in a public database, and should benefit the community of scientists conducting research on this crop species.

\section{FORFURTHERINFORMATION}

Bardil A. et al., 2009. Gene expression divergences between the allopolyploid Coffea arabica and its diploid relatives appears to be environment dependent. In: PAG XVII International Conference, San Diego, 9-13 January 2009. http:/www.intl-pag.org

Joët T. et al., 2009. Metabolic pathways in tropical dicotyledonous albuminous seeds: Coffea arabica as a case study. New Phytologist, 182: 146-162.

Privat B., Bertrand B., Lashermes P., 2008. The coffee microarray project: A new tool to discover candidate genes correlated to quality traits. In: PAG XVI International Conference, San Diego, 12-16 January 2008. http:/www.intl-pag.org
Contact > Benoît Bertrand, Plant Resistance to Parasites [UMR RPB]

\section{PARTNERS}

NESTLE

(France), Institut de recherche pour le développement (IRD, France),

Génoplante (France)

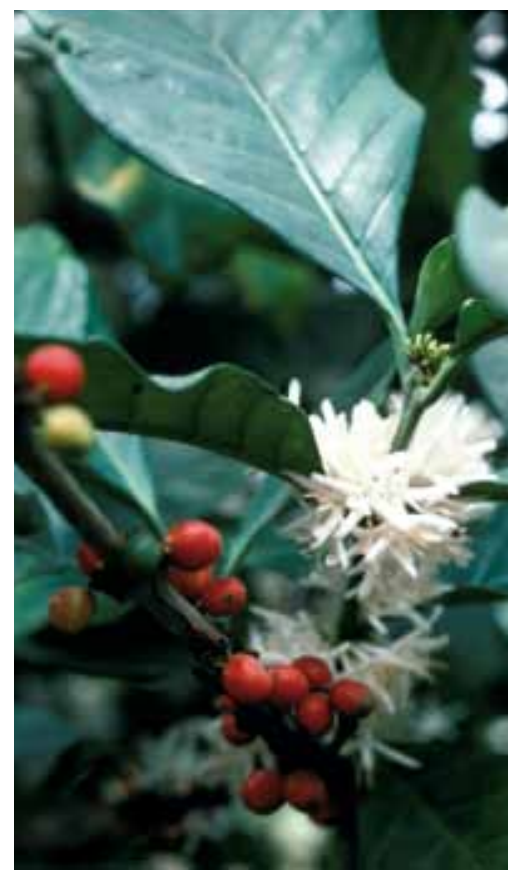

Coffee branch bearing both flowers and berries $\odot$ C. Lanaud/CIRAD

DNA microarray principle

\section{Tissues studied}

Control Sample
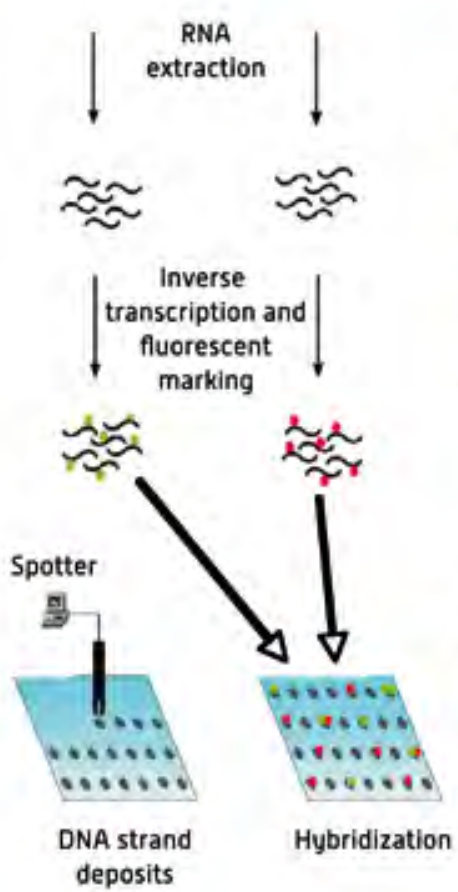
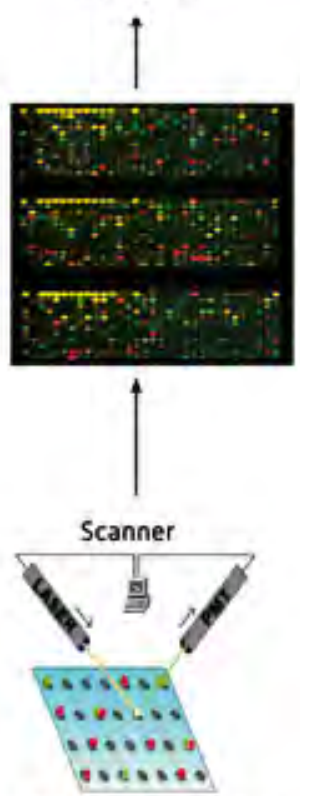

Fluorescent Intensity measurement

\section{Computer} analysis

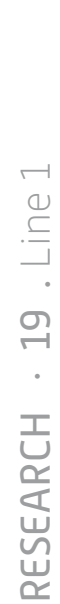




\section{Modelling the impact of refuges on pest resistance}

Mathematical models have been used for several years to study biological systems. They can reveal certain key parameters and shed fresh light on phenomena that have been observed in the field. A CIRAD team is using this type of tool to study the Helicoverpa armigera Bt cotton duo in order to gain insight into the dynamics of this insect pest in different cropping systems.

Thtegrated pest management is implemented to control pest insects through the use of environmentally friendly strategies. One method involves growing transgenic plants that emit toxins that are lethal to some insect pests. What is the risk of the emergence of insects that are resistant to these toxins and what techniques could be used to curb this phenomenon? One strategy recommended by various international bodies is to set up refuge areas in crop fields where non-transgenic plants are sown. This would be a way of maintaining susceptible insects in the field which, when they mate with the few resistant insects present, will give rise to susceptible progeny. This so-called high dose refuge (HDR) strategy is based on three principles: the low initial frequency of resistance genes in the natural population, high expression of the toxin, and the recessiveness of the resistance. Depending on the crop considered, recommendations on the size of these refuge areas may range from $5 \%$ of the total crop field area to $20 \%$, e.g. for Bt cotton.

Concerning the Helicoverpa armigera/Bt cotton duo, especially in West Africa, transgenic crops are grown in alternation with nontransgenic plants (domesticated or wild), thus creating temporal refuges, which are also conducive to the emergence of susceptible insects. A generic mathematical model was built based on impul-
PARTNERS

Institut national de la recherche agronomique (INRA, France), Institut de recherche agricole pour le développement (IRAD, Cameroon), SODECOTON

(Cameroon),

University of Arizona (USA)

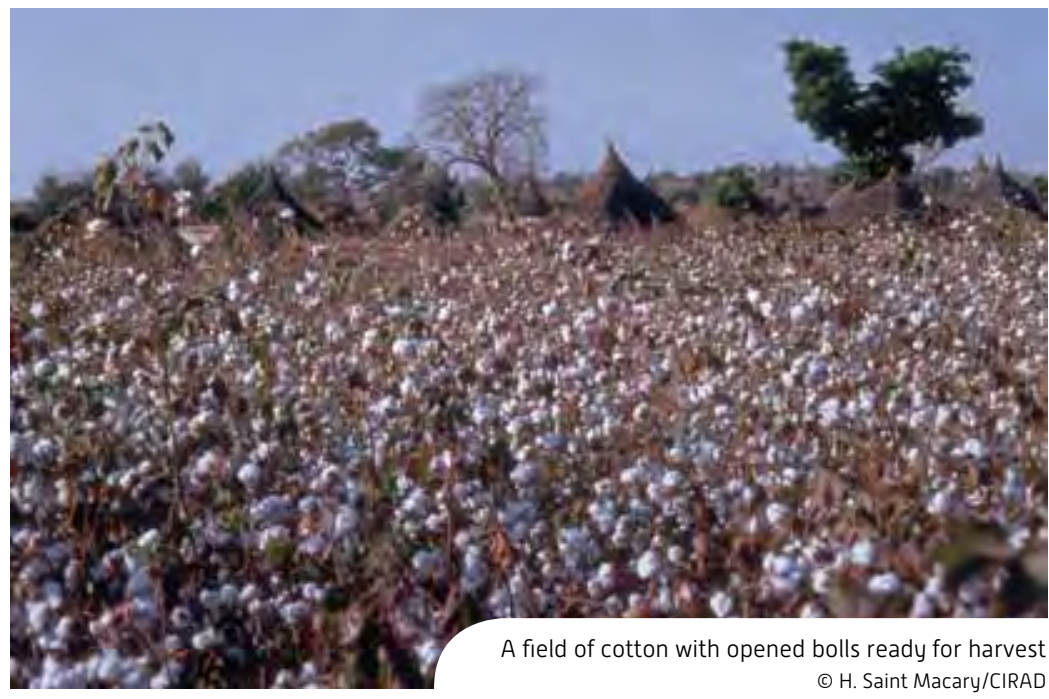

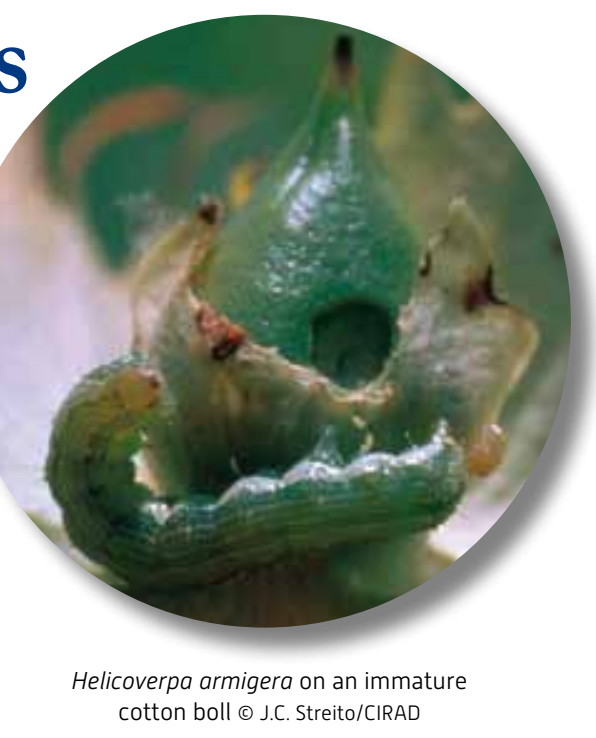

sive ordinary differential equations. It describes the demographic features of resistant and susceptible insects (growth/mortality) subjected to this specific type of cropping system. The use of quite simple mathematical tools reduces the number of parameters required, thus facilitating their identification for the Helicoverpa armigera/ $\mathrm{Bt}$ cotton duo.

The mathematical analysis led to two important results: temporal refuges delay the development of resistant insects, and there is an optimal ratio of transgenic to non-transgenic plants that minimizes the frequency of resistant insects in the natural population. This latter result was quite surprising, but offers an alternative view of the problem and opens new avenues of research. It would now be important to identify the biological processes that underlie this phenomenon.

Contact > Valérie Lemesle, Annual Cropping Systems [UPR]

\section{FORFURTHERINFORMATION}

Mailleret L., Lemesle V., 2009. A note on semidiscrete models in life sciences. Philosophical Transactions of the Royal Society, A 367: 47794799. 


\section{A hybrid coconut to control lethal yellowing disease in Ghana}

Coconut lethal yellowing disease is one of the most serious threats to the coconut sector in Africa and the West Indies. It is induced by phytoplasms, which are small insect-borne intraphloemic bacteria. CIRAD and its Ghanaian partners have developed a resistant hybrid to replace the local variety which is very sensitive to this disease.

A round 10 coconut lethal yellowing resistance field tests, conducted by the Ghanaian Oil Palm Research Institute (OPRI) with the support of CIRAD, have been under way since 1981 . Overall, 38 coconut varieties have been periodically monitored for 15 years, and substantial differences in behaviour between varieties have been observed. The local variety was found to be especially susceptible to lethal yellowing, whereas Sri Lanka Green Dwarf (SGD) and Vanuatu Tall (VTT) showed good resistance. The high genetic diversity of this latter variety should ensure the sustainability of its resistance.

A new hybrid obtained by crossing these two resistant varieties is very

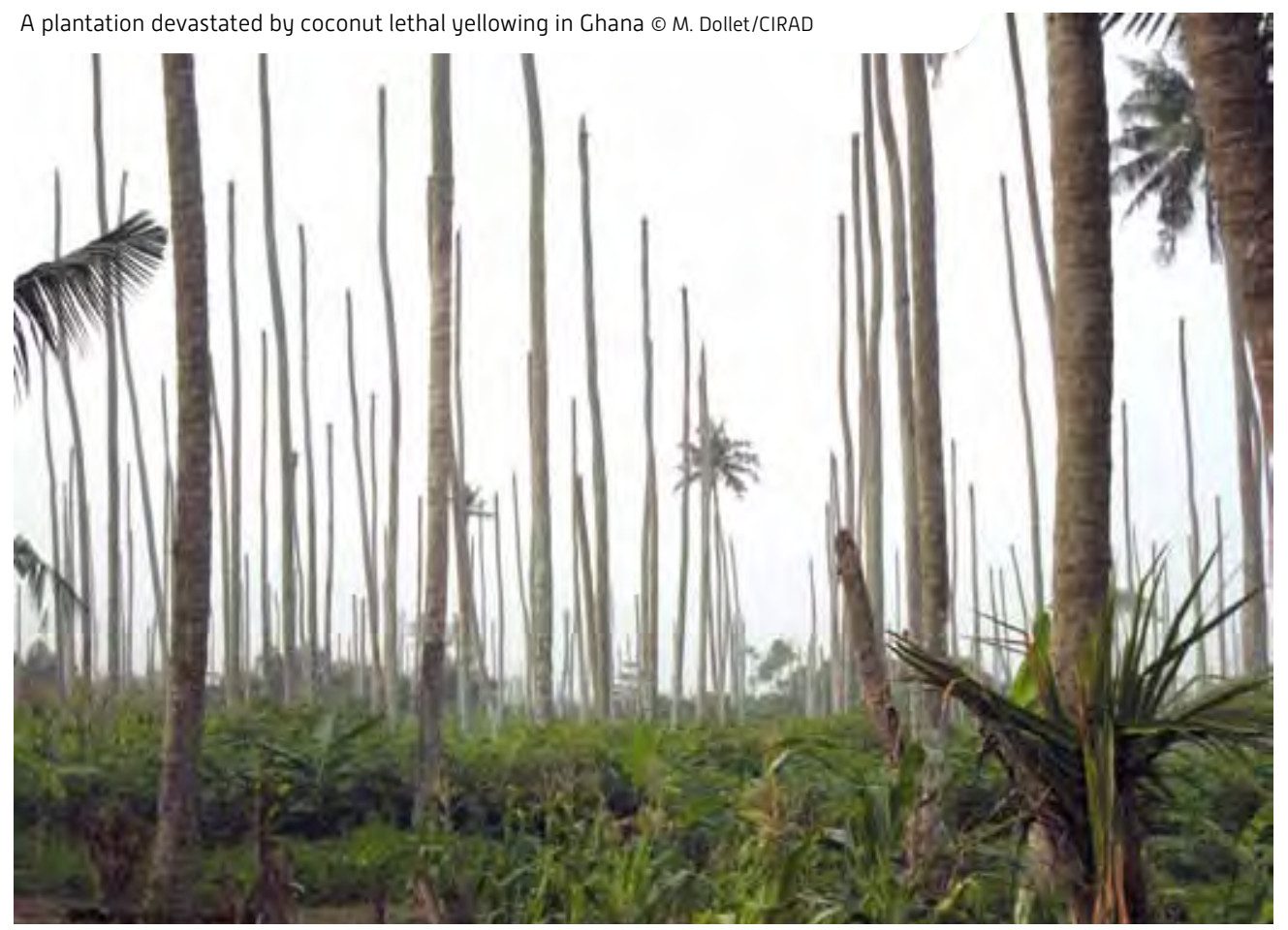

PARTNERS

Coconut Sector Development Project (CSDP Ghana), Oil Palm Research Institute (OPRI, Ghana), Ministry of Foreign Affairs (France), Agence française de développement (AFD, France) essential for controlling lethal yellowing disease. It should be integrated in an overall strategy based on careful choices of planting sites beyond areas most affected by this disease, on diversification of sources of resistance, on good cropping practices and on early removal of diseased trees. Finally, gaining greater insight into the insect vector would facilitate the earlier screening of varieties and the development of new control strategies. To this end, entomological research is currently under way.

Contact $>$ Michel Dollet, Coconut Lethal Yellowing Diseases and Citrus Greening [UPR]

\section{FORFURTHERINFORMATION}

Cocotier et jaunissement mortel. OCL, oléagineux, corps gras, lipides, 2009, 16. http://www.jle.com/fr/revues/agro_biotech/ ocl/e-docs/00/04/4D/E4/article.phtml 


\section{Sorghum genetic diversity in Duupa farmers' fields}

Sorghum cropping and conDuupa society. Duupa farmers do not grow sorghum simply to live, but growing it is the essence of their lives. This unique cultural status determines the dynamics of sorghum genetic diversity. Duupa farmers grow over 40 different sorghum landraces, and each farmer has a unique set of landraces. Four to 12 of these landraces are grown together in a field, thus promoting pollen flow. What biological factors and farmers' practices are responsible for this diversity? How is this landrace diversity being maintained? Researchers addressed these questions by developing a multidisciplinary approach combining genetics, anthropology and agronomy. The study was carried out on a local scale in the village of Wanté to enable an in-depth analysis of the anthropogenic processes that impact the dynamics of sorghum genetic diversity.

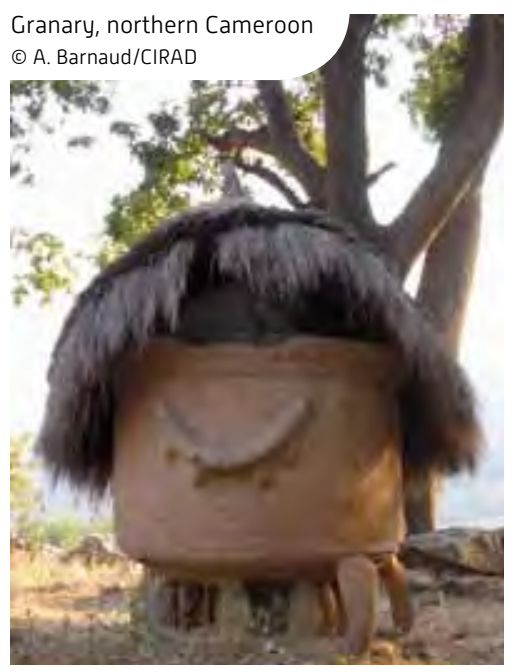

Crop diversity is the result of interactions between human and biological factors. A CIRAD team has just demonstrated that the practices of Duupa farmers - an agrarian community in northern Cameroon-foster the sustainability of local sorghum diversity.

PARTNERS

Centre national

de la recherche

scientifique (CNRS,

France), Mission

d'études pour

l'aménagement

et le développement

de la province

du Nord (MEADEN,

Cameroon)

Pôle de recherche

pour l'organisation

et la diffusion

de l'information

géographique

(PRODIG, France)

SODECOTON

(Cameroon),

University of

Montpellier II

(France), University

of Nanterre (France)

\section{Biological factors and farmers' practices}

One aim was to determine relationships between the landrace name, phenotype and genotype. In traditional agroecosystems, the landrace concept can encompass a broad range of biological states and levels of genetic homogeneity. Twenty-one landraces were assessed using genetic and morphological markers. The landrace names could be classified in two categories. The first includes landraces that form a very large recombinant population and that differ only in terms of a few traits, such as seed colour or panicle shape. The second simply consists of a few landraces whose individuals resemble one another more than they resemble individuals of other landraces.

These findings revealed that, with certain genetically differentiated sorghum landraces, Duupa farmers preserve both the phenotypic and genetic structuring. They also suggest that biological barriers hamper gene flows between some landraces. Outcrossing rates varied markedly between landraces (5-40\%). It would thus be much easier for farmers to maintain a landrace such as see gooriya with a low outcrossing rate $(5 \%)$ than one with a high outcrossing rate like Za'toota (40\%). Yatta, despite its $20 \%$ outcrossing rate, was clearly genetically and phenotypically differentiated. Every year, farmers select their sorghum seed and 13\% of the progeny of the yatta landrace are systematically eliminated, while the remaining $87 \%$, which are considered to resemble the parent plants, are preserved. Duupa farmers can thus counter-select progeny of inter-landrace crosses. The combined effects of human selection and the type of reproduction could explain how differentiated landraces are maintained.

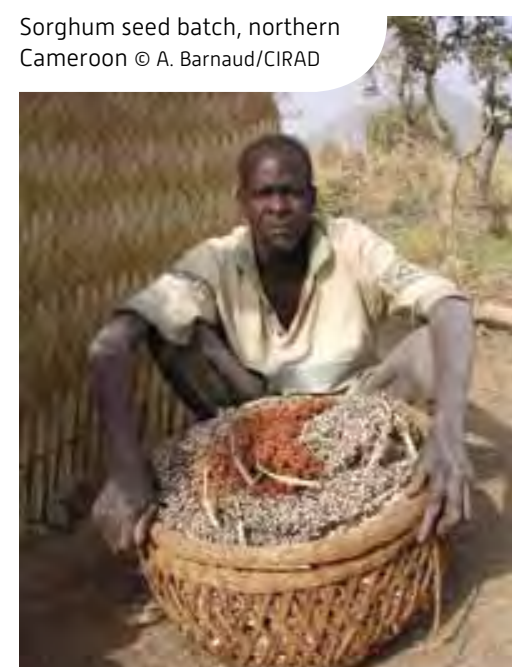




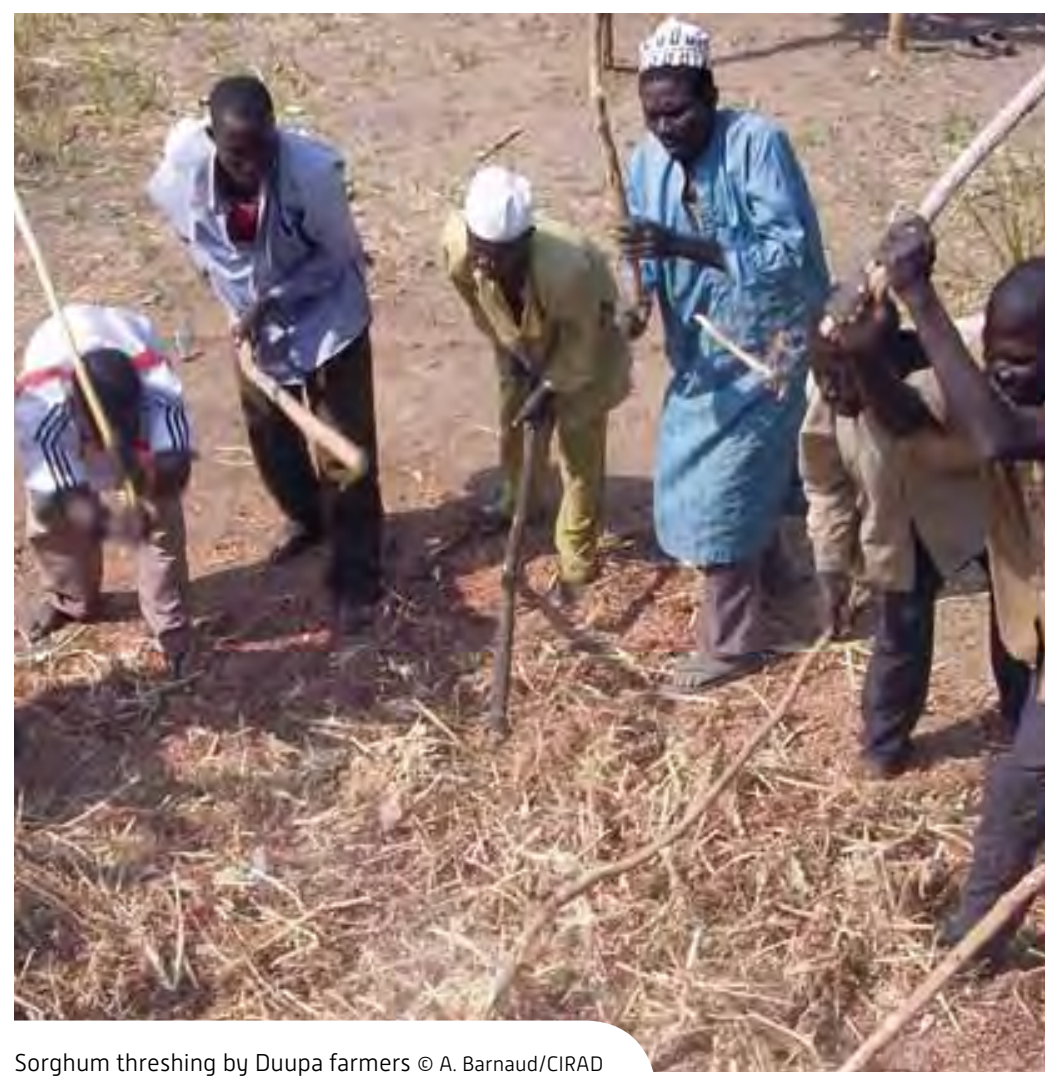

\section{Social dynamics and seed exchanges}

The distribution and evolution of crop genetic diversity directly depend on the farmers' access to conventional landraces, which in turn depends on seed exhanges between farmers and communities. Social relationships among the Duupa people influence the spatial organization of the village land and the exchange dynamics. Threshing has a key role-men may specifically harvest panicles for their seeds whereas women collect food (even though they may use it as seeds). The farmer's social position is crucial in the seed exchange and dissemination dynamics. "Big men" have a greater ability to organize collective work, and their threshing operations attract more people and the associated seed exchanges may be more intense. Seed exchanges are part of the social dynamics, not

Centre of Evolutionary and Functional Ecology (CEFE)

\section{FORFURTHERINFORMATION}

Barnaud A. et al., 2008. Gestion des ressources génétiques du sorgho (Sorghum bicolor) chez les Duupa (Nord-Cameroun). Cahiers agricultures, 17: 178-182.

Barnaud A. et al., 2008. High outcrossing rates in fields with mixed sorghum landraces: how are landraces maintained? Heredity, 101: 445-452.

Barnaud A. et al., 2009. A weed-crop complex in sorghum: the dynamics of genetic diversity in a traditional farming system. American Journal of Botany, 96: 1869-1879.

\section{Agro-ecological crop protection}

Preserving ecosystems and biodiversity while reducing fertilizer and pesticide use are challenges that must now be addressed to ensure that agriculture will be both intensive and environmentally friendly. Innovation is essential for crop pest and disease management. Three experts from CIRAD,

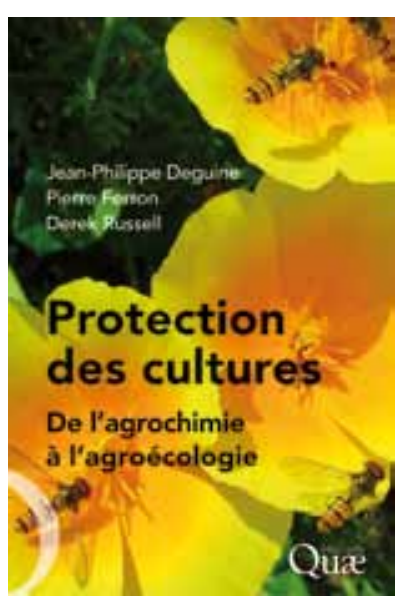
INRA and NRI recount, in a book published in English and French, the evolution of crop protection practices based especially on the history of cotton cropping and the pioneer technical innovations that have shaped it. They analyse the current phytosanitary situation, the limits of pesticide protection, and introduce the agroecology concept to advocate agroecosystem-wide stand management. This crop protection strategy helps maintain bioecological balances between animal and plant communities within agroecosystems, while also preserving and improving the "health" of soils and plant biodiversity. Agroecological crop protection is based on prevention at broader spatiotemporal scales. It combines plant and animal community management and thus contributes to conservation and biological control.
PARTNERS

Institut national de la recherche agronomique

(INRA, France), Natural Research Institute (NRI, UK), University of Greenwich (UK), University of Melbourne (Australia)
Contact > Jean-Philippe Deguine, Plant Communities and Biological Invaders in Tropical Environments [UMR PVBMT]

\section{FORFURTHERINFORMATION}

Deguine J.P., Ferron P., Russell D., 2008. Protection des cultures: de l'agrochimie à l'agroécologie. Versailles, Quæ, 187 p.

Deguine J.P., Ferron P., Russell D., 2009. Crop protection: from agrochemistry to agroecology. Enfield, USA, Science Publishers, 190 p. 


\section{No-tillage with \\ cover crops for the Brazilian Cerrados}

\section{In the humid tropics, the sustainable food production potential under no-tillage systems is highly dependent on the introduction of multifunctional cover crop species. The agroenvironmental interest and socioeconomic relevance of such systems were studied by a multicriteria approach under family farming conditions in the Brazilian Cerrados region.}

Tn humid tropical regions, the harsh climate and fragile soils are responsible for soil fertility degradation and low crop yields. Family farmers, who have limited access to inputs, can often stabilize or even increase their productivity by adopting innovative systems that make effective use of production factors and available natural resources, while minimizing environmental impacts. Cover-crop-based systems are interesting from this standpoint, but their efficacy under hot humid conditions generally depends on the efficiency of the cover crops used. These crops should fulfil agronomic or ecological functions: soil protection, effective resource use, increased biomass production, mineral inputs, weed control, and enhanced ecosystem services. They should also be compatible with the local prevailing production systems.

\section{Direct seeding on forage cover crops for dairy farms}

In the Cerrados region, no-tillage systems have been adopted for the most part on large-scale mechanized farms. They are, however, not applied on family smallholdings even though these farms are often located in highly fragile environments. In the Unai region, these smallholdings are mainly dairy farms. To meet their needs, CIRAD and EMBRAPA developed new maize cropping systems based on no-tillage and direct seeding with forage cover crops such as Brachiria ruziensis and Cajanus cajan, which are relay intercropped with maize.

From an agronomic perspective, these cover crops should be managed in such a way that maize crop productivity is not affected and biomass production is maximized. Experiments were thus carried out under controlled conditions and on farms. It was found that if the cover crop was planted between the maize rows very early, there was no negative impact on the maize crop while the total biomass could be increased twofold, especially with the maize-legume system, which was more efficient in this respect than the maize-grass system. However, when the cover crop

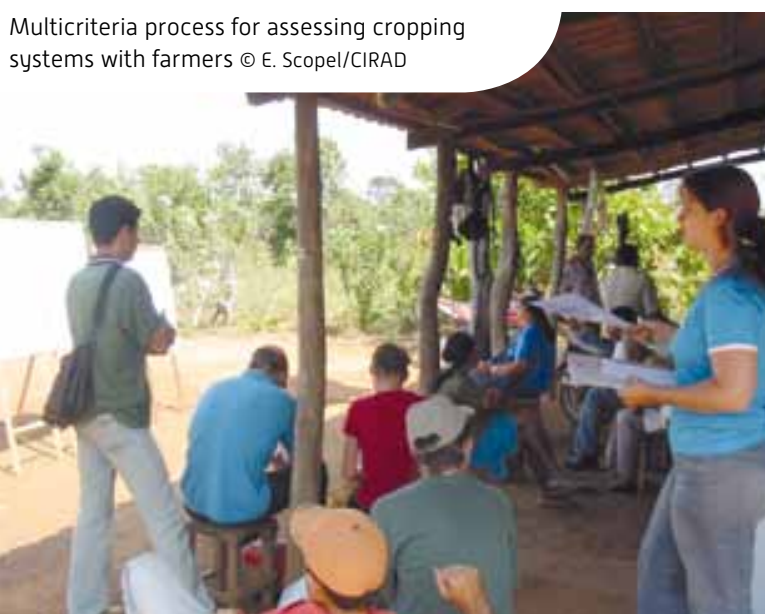

PARTNERS

Empresa Brasileira de Pesquisa Agropecuária (EMBRPAP, Brazil), Federal University of Pelotas (Brazil), Institut national de la recherche agronomique (INRA, France), Montpellier SupAgro (France) 

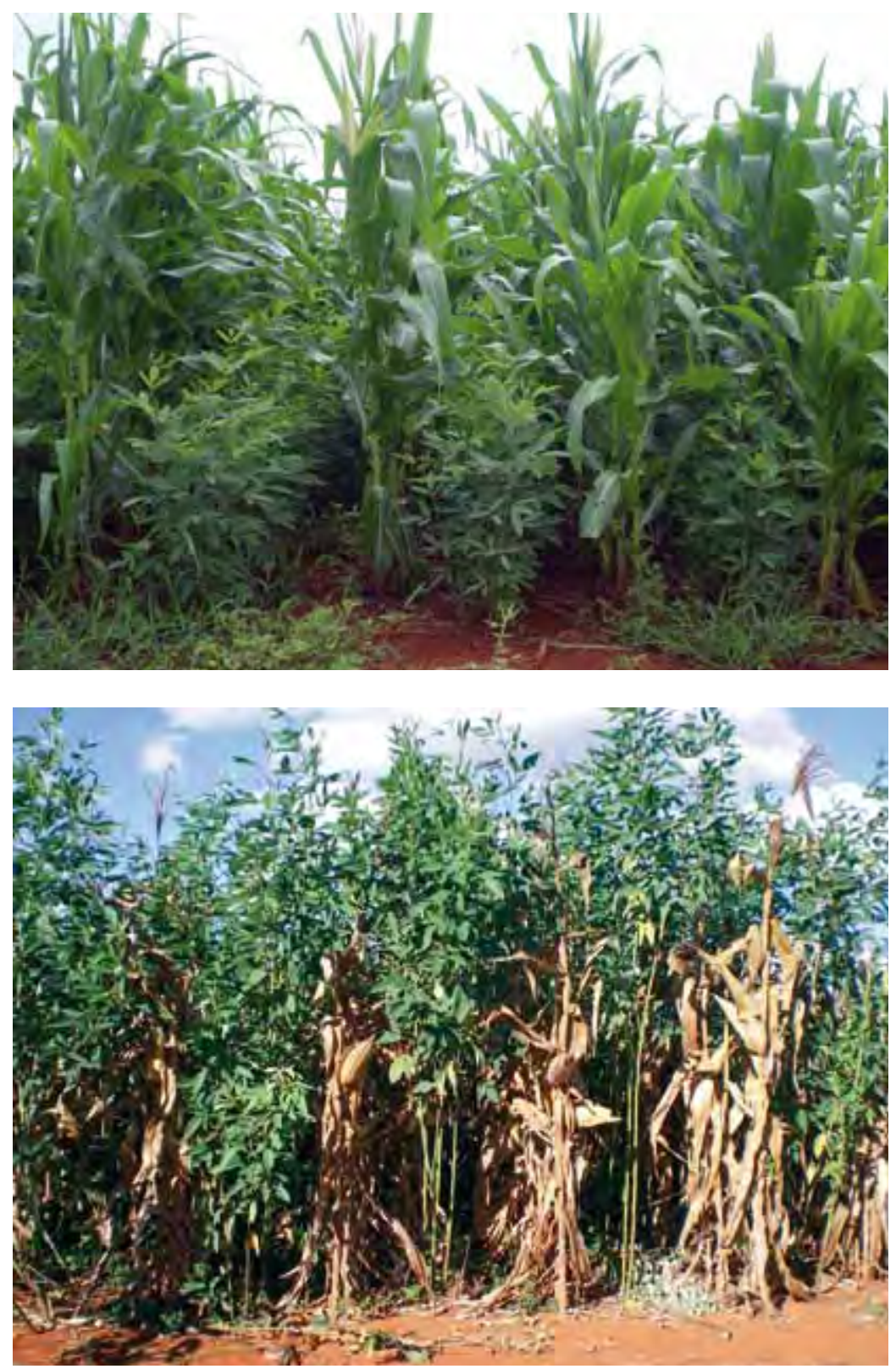

was planted later, it was hampered by very heavy competition with the maize crop and the total biomass of the system was markedly reduced as compared to the early sowing strategy.

\section{A multicriteria}

\section{assessment to gain} further insight into these systems

Researchers conducted a multicriteria assessment based, as

on social or on environmental factors, so as to measure the impact of these new cropping systems, which considerably alter the overall organization of farming activities. In the first case, their approach was based on multi-objective optimization under linear programming, using farm models in which direct seeding is offered as an alternative. They thus showed that these systems were only economically
A maize-Cajanus association, in the middle (top] and at the end (bottom) of the maize cropping cycle, in family farming systems located in the Brazilian Cerrados region. Early sowing of the legume cover crop between maize rows leads to a twofold increase in biomass production without reducing maize yield. The maize crop dominates the cover crop throughout its cycle, and the cover crop takes over only at the end of the maize cycle, when it begins withering (c) A. Bocar Baldé/ CIRAD warranted to the extent that the additional work they required was offset by the quantity and quality of the additional forage produced. In the second case, based on a hierarchical multicriteria method derived from the MASC model, they also showed that in all situations these systems seemed definitely advantageous and made better use of natural resources. Farmers were nevertheless still reluctant to adopt these systems. We thus concluded that in the South, it was essential to tailor this assessment to family farms and to farmers' concerns. Research is under way to participatively build a hierarchical multicriteria model.

These studies showed that several tools and different viewpoints are necessary when designing innovative systems, with the direct participation of researchers and users at different stages of the proposal, assessment and adaptation of technical options process. In the coming years, research will be focused especially on setting up new forage production strategies compatible with intensive dairy production, and on the role therein of maize production and no-tillage systems with cover crops.

Contact > Eric Scopel, Annual Cropping Systems [UPR]

\section{FORFURTHERINFORMATION}

www.agroecologie.cirad.fr

Affholder F. et al., 2010. Constraints to farmers' adoption of direct-seeding mulch-based cropping systems: A farm scale modeling approach applied to Systems, 103: 51-62.

Maltas A. et al., 2009. Cover crop and nitrogen effects on maize productivity in no-tillage systems of the Brazilian Cerrados. Agronomy Journal, 101: 1036-1046.

Oliveira M.N. et al., 2009. Efeitos da introdução do sistema de plantio direto de milho por agricultores familiares do municipio de Unaí, MG (Cerrado Brasileiro). Pesquisa Agropecuária Tropical, 39: 51-60. the mountainous slopes of Viet Nam. Agricultural 


\section{Cocoa mirid control}

\section{recommendations}

\section{Mirids are the most dangerous of all insects in the world that feed on and thus damage cocoa pods and shoots. In Cameroon, where cocoa trees are cultivated in complex agroforestry systems, CIRAD researchers studied cocoa mirid population dynamics and influencing ecological factors, in order to draw up recommendations on practices that could enable cocoa growers to control this plague.}

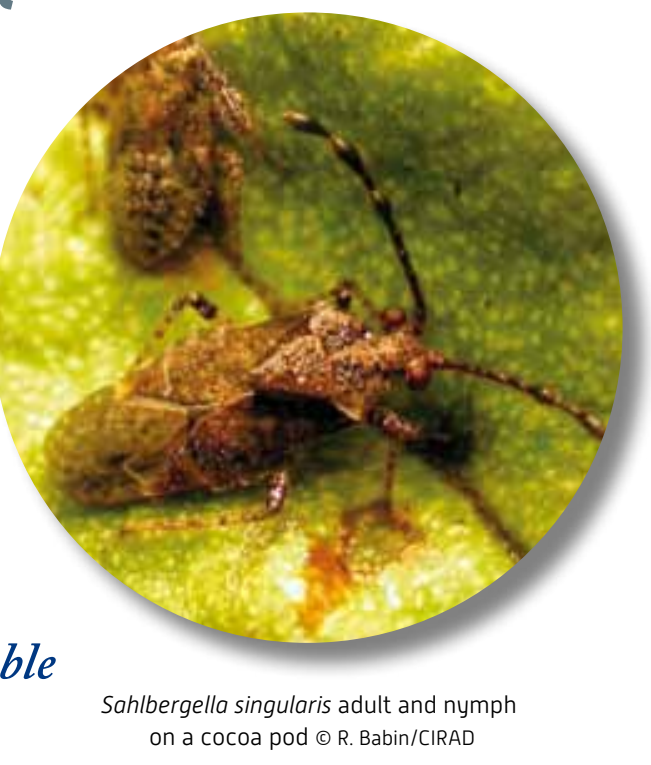

$\triangle$ frica is the top cocoa producing region, accounting for over $70 \%$ of global production. In West and Central Africa, this crop is attacked by two mirid pests, i.e. Sablbergella singularis and Distantiella theobroma. These two bugs feed on cocoa pods and shoots, thus inducing tissue necrosis, and infested cocoa trees quickly become non-productive. These attacks are responsible for cocoa production losses of 25-40\% in Côte d'Ivoire and Ghana, the largest producers in the region.

In Cameroon, where $S$. singularis is mainly found, mirids are considered to be a national plague. However, national cocoa protection campaigns were halted in the 1990s, and mirid populations have since been increasing to the detriment of plantations. Small-scale cocoa growers cannot efficiently and sustainably invest in cocoa mirid control because of the volatility in world cocoa prices and the high cost of inputs. Few studies have analysed the complex agroforestry systems in which cocoa
PARTNERS

Cocoa Research Institute of Nigeria (CRIN), Ecole d'ingénieur d'agrodéveloppement international (ISTOM, France), Institut de recherche agricole pour le développement (IRAD, Cameroon), Cocoa growers' organizations (Cameroon),

University of

Dschang (Cameroon), University of Yaoundé I (Cameroon), University of Montpellier III (France), Ministry of Foreign Affairs (France) trees are conventionally grown, and little is known about the ecology of $S$. singularis in these systems. With the aim of improving mirid pest management recommendations, CIRAD researchers focused on populations of this particular mirid species and looked at how ecological factors influence their dynamics.

\section{S. singularis population dynamics}

Demographic aspects (fecundity, survival, longevity) of this mirid were first studied in a laboratoryreared population. The slow growth rate of this insect explains why its population numbers are often low in plantations, despite

Maps of S. singularis population spatial distributions in the Yaounde region in 2006 (C) and 2007 (D) in comparison to maps of the positions and coverage of shade trees $(A)$ and the percentage of lighting under the shade tree canopy (B). Cn: Cola nitida, Csp: Citrus sp., De: Dacryodes edulis, Eg: Elaeis guineensis, Fe: Ficus exasperata, Fm: Ficus mucuso, Gk: Garcinia kola, Mi: Mangifera indica, Me: Milicia excelsa, Pa: Persea americana, Sd: Spondias dulcis

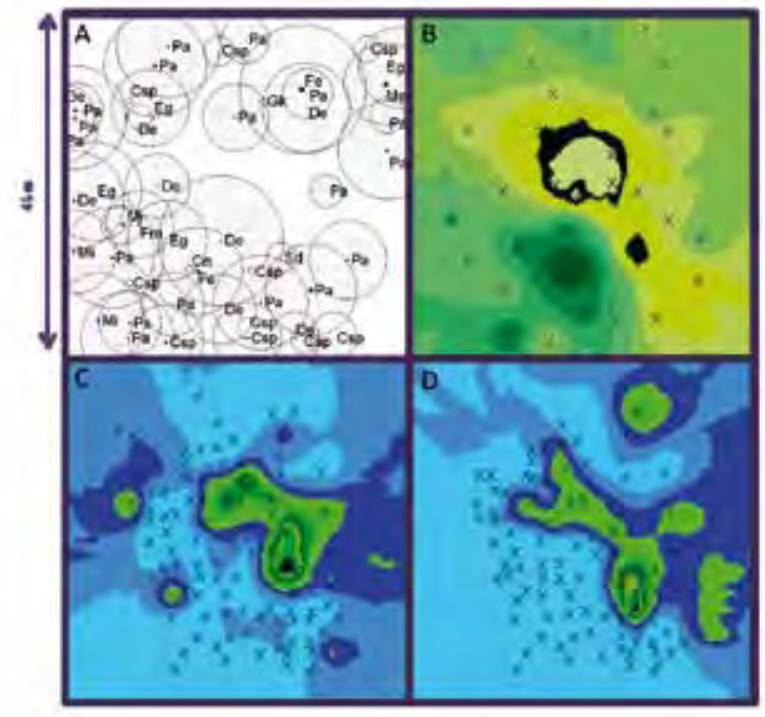

W light transmitted to cocoa plants

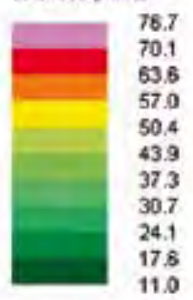

Mirid density! cocoa piant

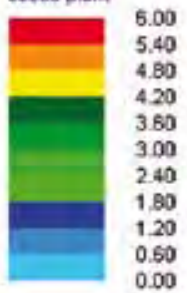


marked seasonal variations, with yearly peak outbreaks. Female fecundity is the key parameter governing these variations: population growth is associated with maximal female fecundity, while declines are linked with sharp reduction in fecundity rates. The cocoa fruit development stage is also a prime factor, as young pods provide females with an optimal food source for reproduction.

The results of a study carried out in conventional agroforestry systems in central Cameroon suggest that the type of landscape around plantations has very little impact on mirid populations. However, cropping conditions within plots, especially cropping practices, are crucial. As expected, both pesticide treatments and dense forest shade reduced population numbers. Hybrid cocoa varieties were also more susceptible to mirid infestation than conventional varieties.

\section{Shade-a key factor}

Mirid populations are irregularly distributed in plantations. They aggregate in groups of 20-30 adjacent cocoa trees, surrounded by healthy trees. The formation of these "mirid pockets" depends on the sunlight conditions, as clearly revealed in recent studies. These mirid pockets are usually located in zones where sunlight is maximal due to openings in the shade tree canopy. Forest trees generally provide more uniform shading than fruit trees and are therefore less conducive to the formation of mirid pockets.

Cocoa growers generally do not apply researchers' recommendations, which need to be discussed and tailored to agroforestry systems in Cameroon. As no alternatives are available, rational chemical control is still the main component of IPM programmes. A treatment calendar was proposed to growers. Using new pesticide molecules, treatments are more efficient, cost-effective and environmentally friendly. Moreover, good shade management and maintenance practices in plantations, which restrict the vegetative growth of cocoa trees, are also essential in controlling this pest.

Contact > Régis Babin, Controlling Pests and Diseases in Tree Crops (UPR)

\section{FORFURTHERINFORMATION}

Babin R. et al., 2008. Rearing method and life-table data for the cocoa mirid bug Sablbergella singularis Haglund (Hemiptera: Miridae). Journal of Applied Entomology, 132: 366-374.

Babin R., 2009. Contribution à l'amélioration de la lutte contre le miride du cacaoyer Sablbergella singularis Hagl. (Hemiptera: Miridae): influence des facteurs agroécologiques sur la dynamique des populations du ravageur. $\mathrm{PhD}$ thesis, University of Montpellier III, 201 p.

Babin R. et al., 2010. Impact of shade on the spatial distribution of Sablbergella singularis (Hemiptera: Miridae) in traditional cocoa agroforests. Agricultural and Forest Entomology, 12: 69-79.

Cocoa agroforestry plantation in the Yaounde region, Cameroon @ R. Babin/CIRAD

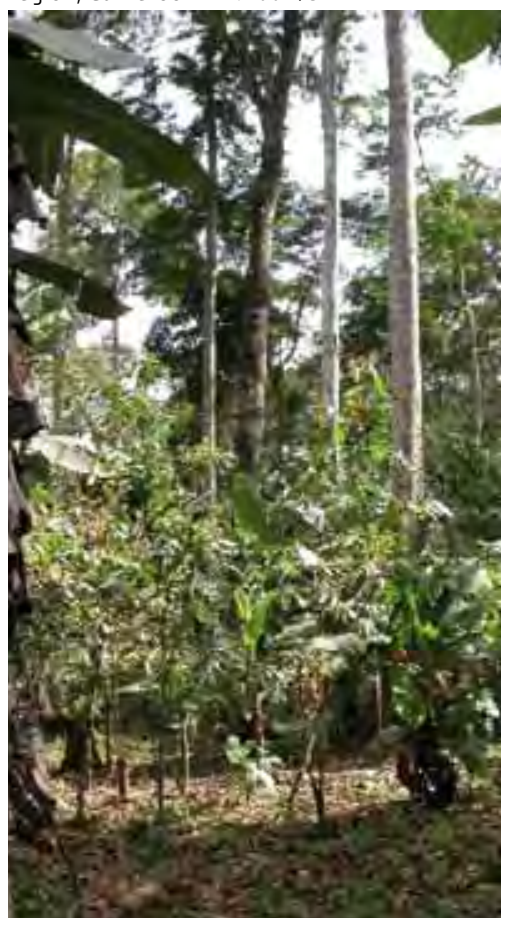

Collaborative statistics on livestock in southern Africa

The aim of the collaborative Livestock Information Management System (LIMS), developed for the Southern African Development Community (SADC), is to share a range of thematic and statistical information on the livestock sector (populations, infrastructures, regional trade, health, etc.) that is hosted by different organizations. This system, which was developed and set up with the technical support of CIRAD, is an observatory on the status and performances of the livestock sector. It includes several components that address specific needs and functions, such as communication between stakeholders and data representation for planning purposes. A collaborative statistics software tool pools information from different sources within the 15 countries in the subregion, while respecting the original spatiotemporal scales. A portal was developed that includes various tools such as software manuals, discussion forums and web mapping tools.

Contact > Pascal Bonnet, Livestock Systems and Animal Product Management [UPR]

PARTNERS

Food, Agriculture and Natural Resources (FANR, Botswana), Southern African

Development Community (SADC, Botswana)

\section{FORFURTHER} INFORMATION

Bonnet P. et al., 2009. Collaborative statistics for livestock development, animal production and health, an example in the SADC region with the LIMS livestock information and management system, a regional system based on Web 2.0 principles. In: ISVEE XII, 10-14 August 2009, Durban, South Africa.

\section{http://aims.sadc.int/livestock/print-lims/}

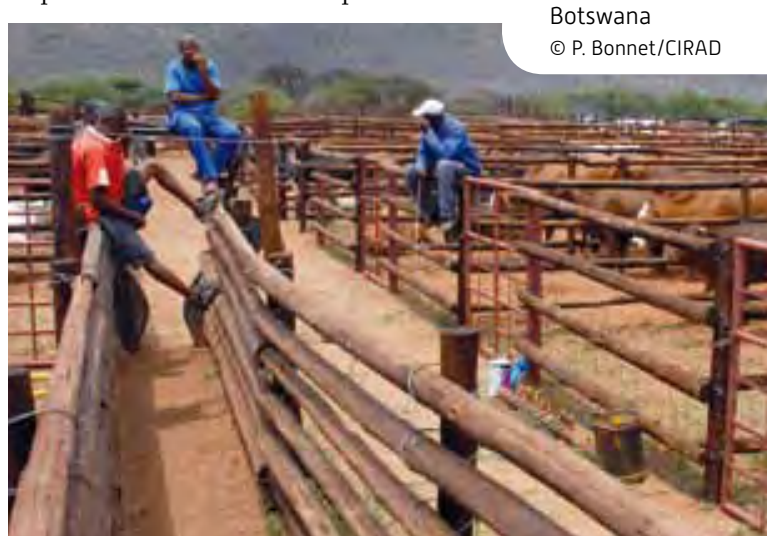

In Botswana,

livestock auctions (cattle, sheep and goats) are the most common way of marketing breeding animals and weaned animals for fattening, Lobatse, Botswana () P. Bonnet/CIRAD 


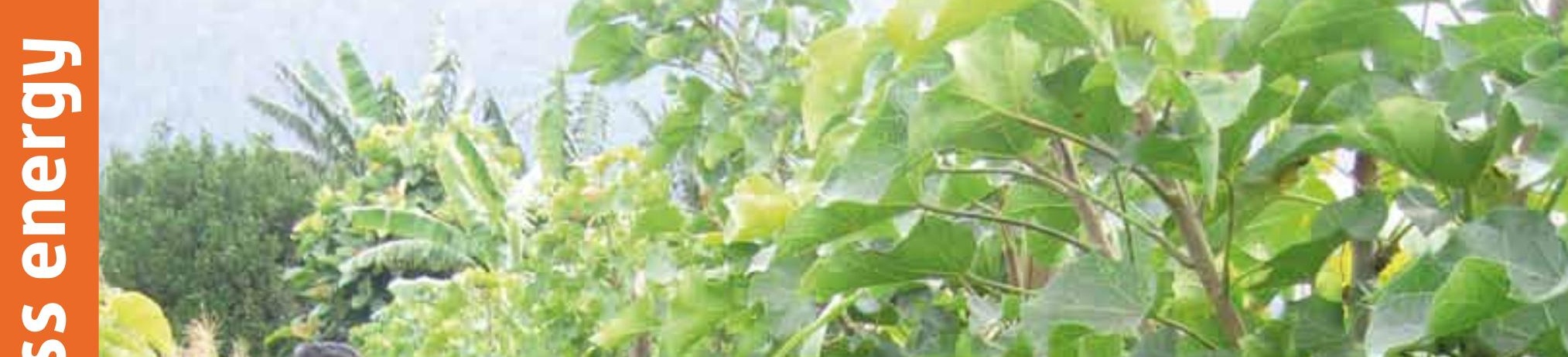

要

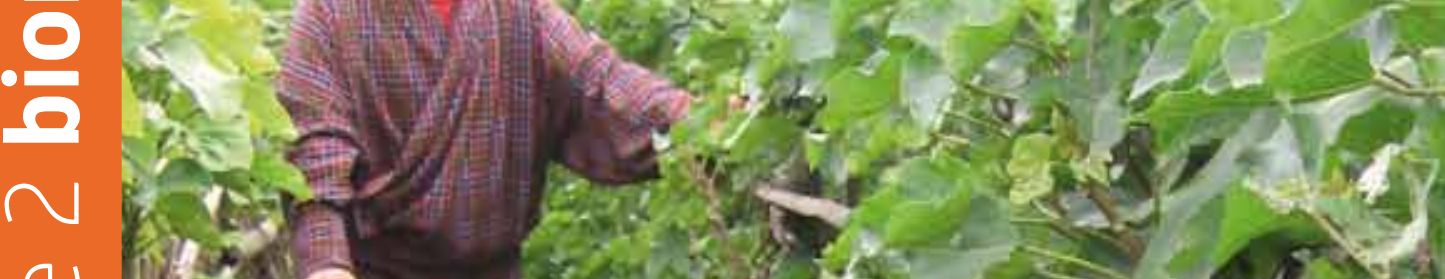

ㄴ) 120

$\subseteq, \sqrt{2}$

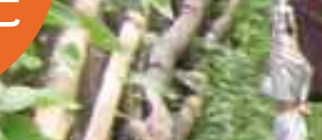

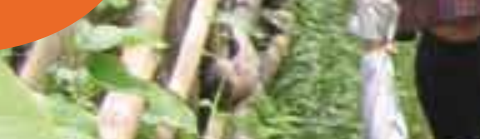
iffes Nhe

1 Mets

1

3 का

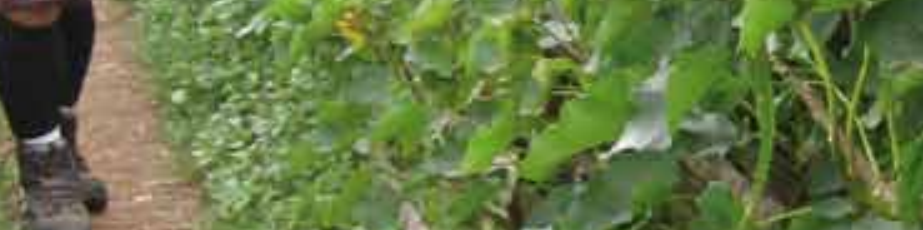

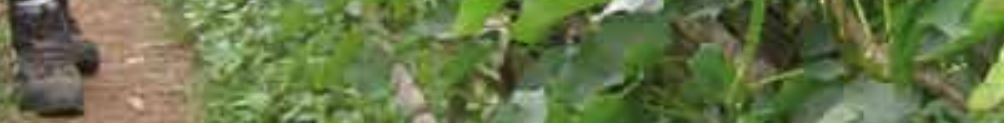

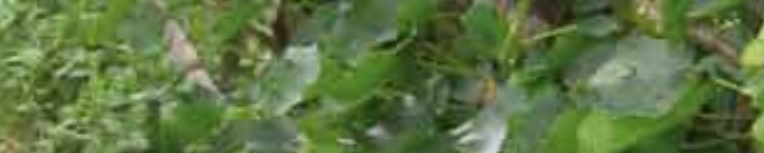

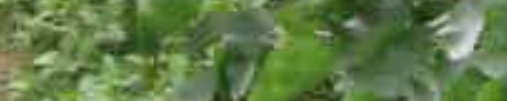

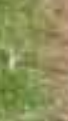

8

intanting if

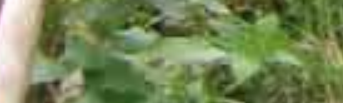
a.jog

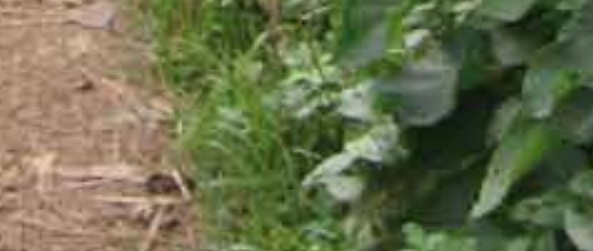

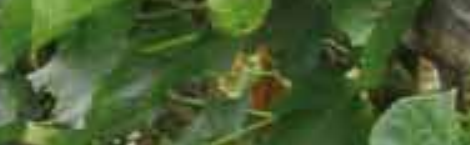
$18=5 \times 9 \cdot 2$ (2) 

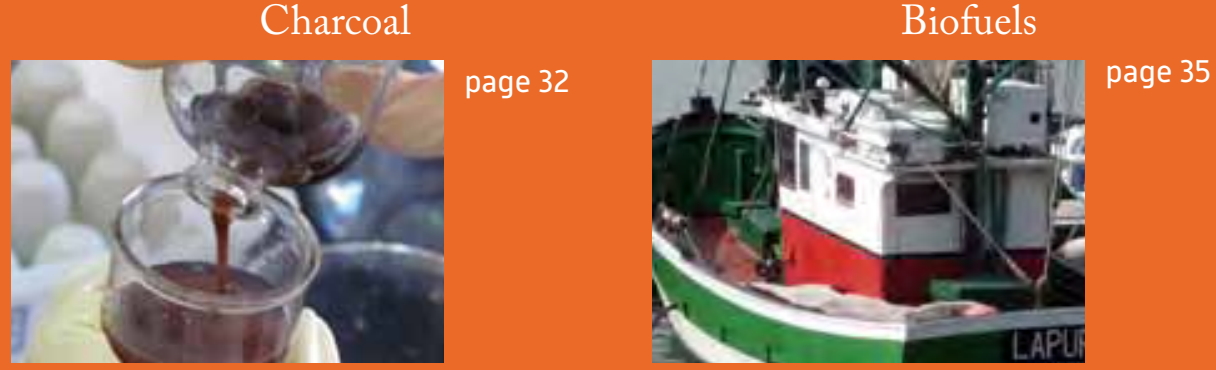

\section{What types of energy for the South?}

For CIRAD, the main challenge relating to biomass is responding to the problems surrounding energy supplies in developing countries. This is one of the six priority lines of research set out in its strategy and is primarily being tackled by three of its research platforms in partnership: the Forests and Biodiversity International Research Unit (URP) in Madagascar; the Agroforestry Systems with Perennial Crops Research Platform in Partnership (PCP) in Costa Rica; and the Institut international d'ingénierie de l'eau et de l'environnement (2IE), a research and higher education platform set up to provide its 14 members in Africa with engineers capable of responding to the development needs of rural areas. The programmed thematic operation on energy in the South translates these challenges into research questions: how can we define and assess the potential of biomass energy for improving the living conditions of rural populations in the South? In what way is biomass energy more appropriate than other energy sources? These questions are being tackled at several study sites in Brazil, Burkina Faso, Mali and Madagascar.

\section{The new national energy alliance}

As an associate member of the new Alliance nationale de coordination de la recherche pour l'énergie, CIRAD is involved in a thematic group working on biomass and looking at the conditions for developing bio-energies that would ensure maximum benefits for local people: using biomass, hence adapting and optimizing existing production systems; setting up production systems devoted to bio-energies; and including bio-energy production as a breeding and varietal improvement objective. CIRAD researchers are also working to analyse the ecological and economic impacts of biomass production.

\section{Researcher schools and PhD teaching}

The European Commission, the Agence nationale de la recherche and the Agence de l'environnement et de la maîtrise de l'énergie have encouraged organizations to set up structural programmes on bioenergies, often covering several disciplines, which has led to the emergence of new communities. To help project leaders build partnerships and fuel debate within steering committees, CIRAD and INRA organized a researcher school in January 2009, with three main objectives: acquiring new knowledge (methods, concepts, data); innovating, in terms of systems, processes and end or intermediate products; and developing ex ante methods for assessing these innovations from various angles, including the ecological balance of natural habitats, agricultural and industrial supply chains, and international markets.

CIRAD is also involved in $\mathrm{PhD}$ teaching overseas. It is supporting the Institut international d'ingénierie de l'eau et de l'environnement (2IE) in setting up an international, inter-university $\mathrm{PhD}$ programme.

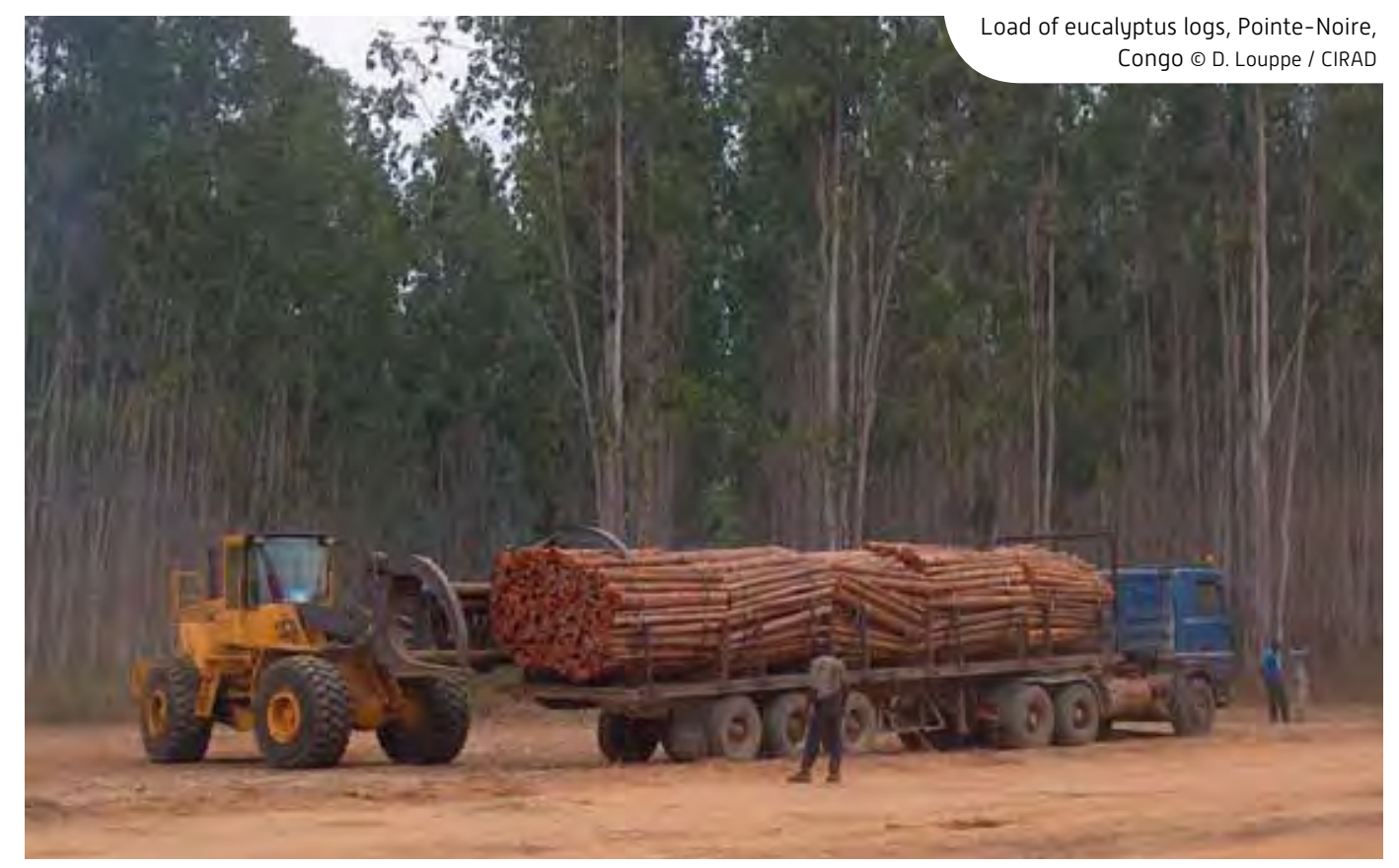




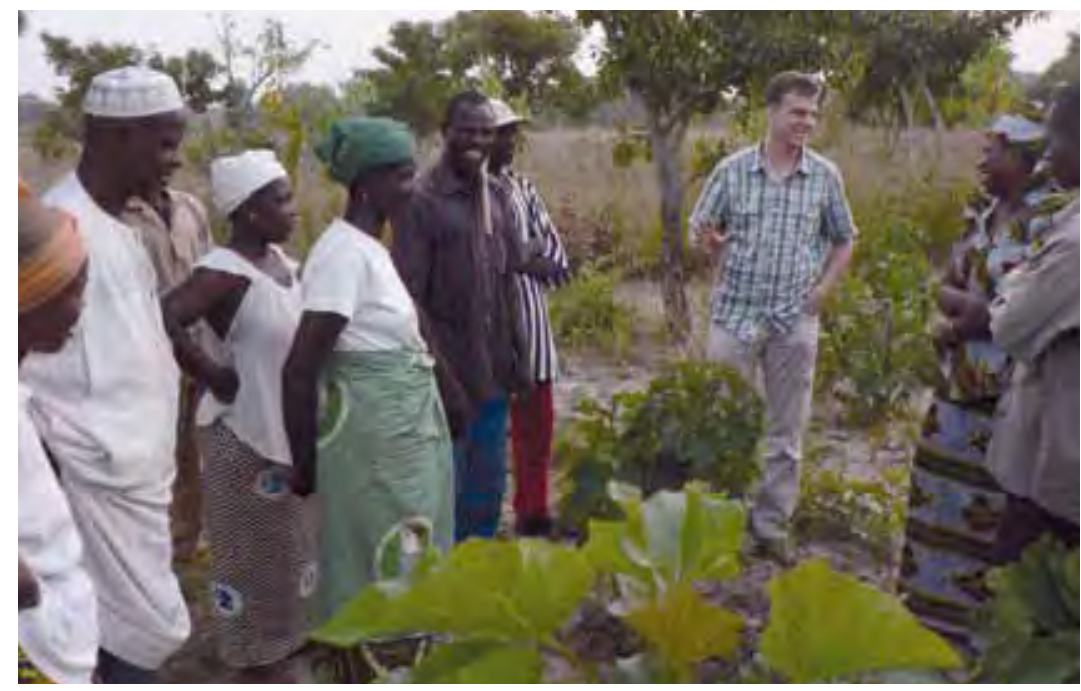

Jatropha curcas, a fuel of the future for the South?
Dhysic nut, Jatropha curcas, a wild Lush that originated in Central America but has been acclimatized in Africa and Asia, is traditionvegetable gardens, since its toxic properties naturally deter animals. It is also a medicinal plant, and its oil is used to make soap. The oil price rises in 2008 triggered new enthusiasm for using this oil as a fuel.

There was some initial interest in physic nut oil in the 1980s, and CIRAD has been working since then to determine how it could be used in diesel engines. However, while the original projects were content merely to pick the nuts ally used as a live hedge around from live hedges, the current projects are on another scale altogether, requiring larger quantities of oil and thus field plantings. This new cash crop has been a godsend for West Africa, where the move away from cotton, which is now less lucrative, has freed agricultural land.

Contrary to what has often been claimed, physic nut does not produce economically acceptable yields in marginal soils or adverse environmental conditions. It is indeed highly drought-resistant,

\section{High drought resistance but low productivity}

Tour of physic nut plot, left; Jatropha curcas fruits, right (c) R. Pirot/CIRAD

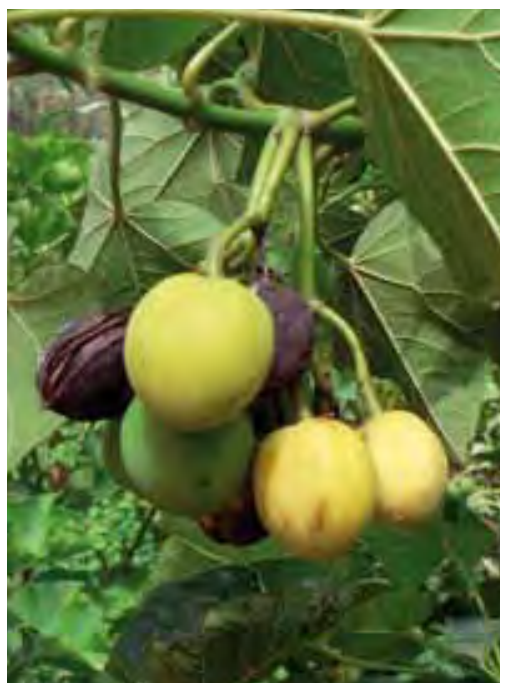

Physic nuts contain oil that can be used as a fuel for diesel engines, provided certain precautions are taken. The latest oil crisis has revived interest in physic nut oil. However, what are the conditions for truly profitable production? CIRAD has chosen to tackle this issue from a local development angle, and to work on an energy self-sufficiency project in Mali, where physic nut oil and its co-products are used in the zone in which they are produced. 
but to produce nuts, it requires at least some water and nutrients, like cotton, with which it shares a production zone in Sudano-Sahelian conditions.

The main problem is the crop's poor productivity. Here too, some of the figures quoted are pure fiction. Some long-term projects have provided a realistic picture of the yields that can currently be expected: they vary from 1200 to $1500 \mathrm{~kg}$ of dry nuts per hectare, or 400 to $500 \mathrm{~kg}$ of oil. Work has recently been undertaken on the crop's cultivation, but the results will not be available for several years, and as for improved genotypes, their development will take at least a decade or so.

\section{In Mali, an energy self-sufficiency project}

CIRAD is tackling this operation from a local development angle, the aim being to improve the living conditions of local people by ensuring their energy selfsufficiency. To this end, CIRAD has opted to support an ecotourism project in Mali, managed by the Association d'Entraide pour le Développement Rural, which intends to replace the diesel it uses for its electricity generating sets with physic nut oil.

The initial research quickly produced answers as to how to grow the plant, which meant that farmers were rapidly able to set up plantings. A bibliographical summary has been produced, and agronomic trials have been arranged. The farmers involved are now being monitored to see how the crop is progressing and whether they have taken on board the techniques proposed to them. A varietal breeding programme was recently launched, with CIRAD in charge of technico-economic monitoring of the supply chains for the future cultivars. Lastly, research is under way with a view to addressing the environmental concerns raised by the crop, primarily the use of press cake, the toxic waste left after pressing. The cake could be used as an organic fertilizer, but it is not yet known what becomes of the toxins once the cake has been incorporated into the soil.

\section{A delicate crop}

The latest results concern crop establishment in the SudanoR., 2008. Rapport de

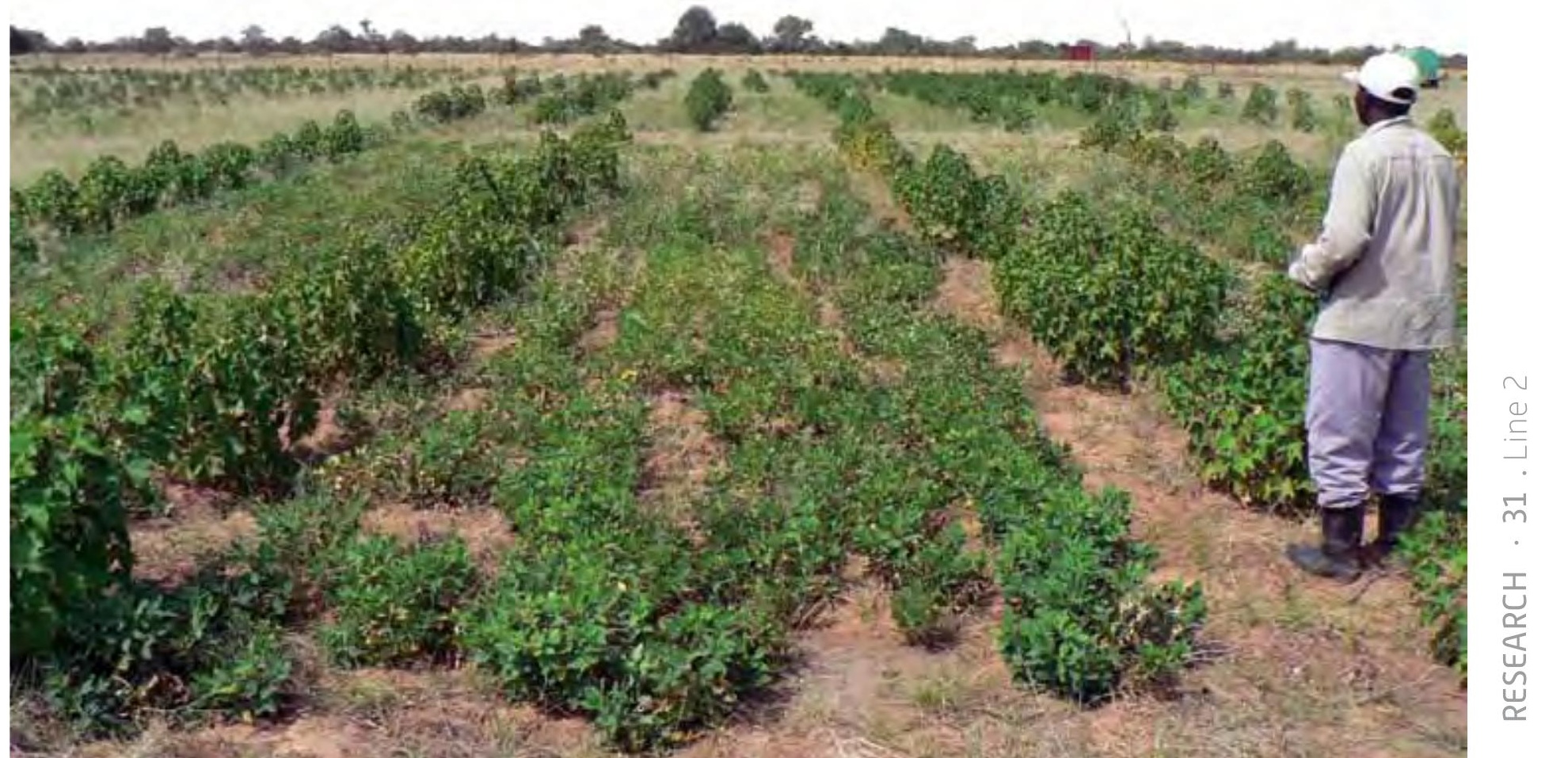

PARTNERS

Association

d'Entraide pour le

Développement

Rural (Mali),

Tuck Foundation,

European Union,

University of Berne

(Switzerland),

University of

Wageningen

(Netherlands)

FORFURTHER

INFORMATION

Domergue M., Pirot synthèse bibliographique sur Jatropha curcas L. Montpellier, CIRAD, $118 \mathrm{p}$.

Ndong R. et al., 2009. Life cycle assessment of biofuels from Jatropha curcas in West Africa: A field study 1: 197-210. GCB Bioenergy,

Sahelian zone: the operation requires considerable care, using robust plants produced in a nursery, planted after the first rains in a tilled soil with a little organic matter. Taking such precautions facilitates crop establishment and provides it with the right conditions to be able to withstand the long dry season. Rapid development during the second rainy season favours the development of the first flowers and fruits, although yields are modest. Full fruiting does not occur until the tree reaches biological maturity, some four to five years after planting.

To date, some 500 farmers have the region. The association provides them with technical support and guarantees to buy the nuts produced. While the income generated is modest for the time being, there are high hopes of obtaining high-yielding varieties in the near future, which should ensure energy self-sufficiency and the development of the local economy.

Physic nut experimental plots, Mali

Contact $>$ Roland Pirot, Annual Cropping Systems shown an interest in physic nut in 


\section{Producing charcoal for energy purposes by pyrolysis}

\section{One way of reducing greenhouse gas emissions is to use charcoal from}

lignocellulose biomass, since it is neutral in terms of emissions. However, it has to be produced under conditions that do not threaten either the environment or local people's living conditions. Tropical forest plantations could satisfy these requirements. In Brazil, CIRAD and its partners are working on biomass from eucalyptus forest plantings and producing charcoal from that biomass by pyrolysis.

Tossil carbon is the main source To cut such emissions, it could be worth using the "plant" carbon found in lignocellulose biomass, which accounts for $50 \%$ of the biomass on average. However, that biomass needs to satisfy certain requirements: it has to be produced sustainably, so as not to lead to deforestation, to achieve high productivity without impoverishing the soil, and to avoid generating competition between food and non-food uses of the land available.

Only tropical forest plantations and agricultural waste can satisfy these requirements in the short and medium term, but these resources bring their own constraints, linked to their high heterogeneity and low energy density, and they have to be converted by pyrolysis. This conversion, which involves heat treatment in an oxygen-free environment at $350^{\circ} \mathrm{C}$, results in charcoal whose physicochemical and mechani- cal properties are suitable for industrial applications. It is for this reason that CIRAD and its Brazilian partners are working on eucalyptus forest plantations, in the laboratory and also on an industrial scale.

\section{Eucalyptus plantations to produce energy}

Research is centring on the relations between the characteristics of eucalyptus, pyrolysis parameters, and charcoal yields and quality.
PARTNERS

AgroParisTech, H\&R Ingénierie, Federal University of Lavras (UFLA, Brazil), Vallourec \& Mannesmann Florestal (Brazil)

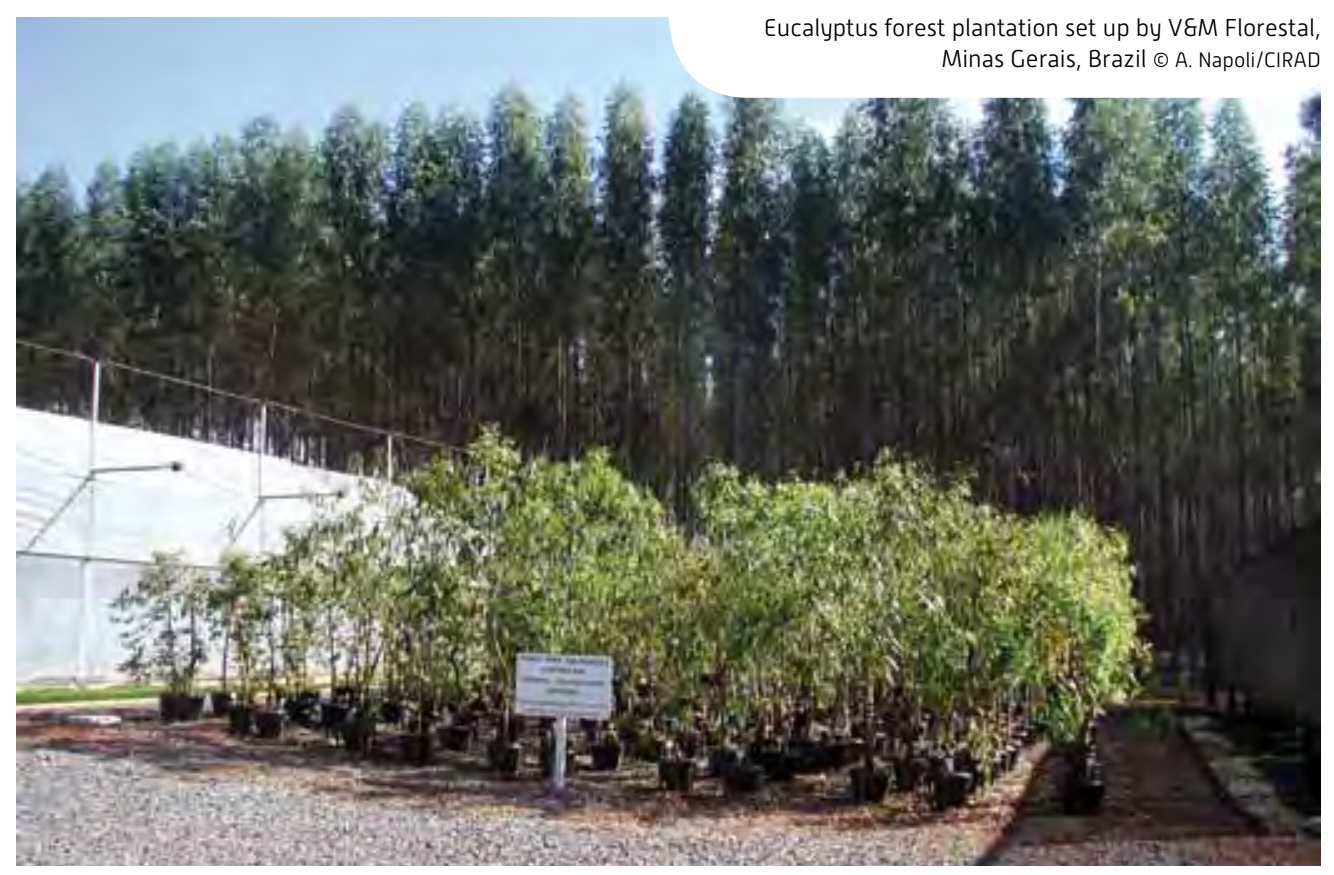




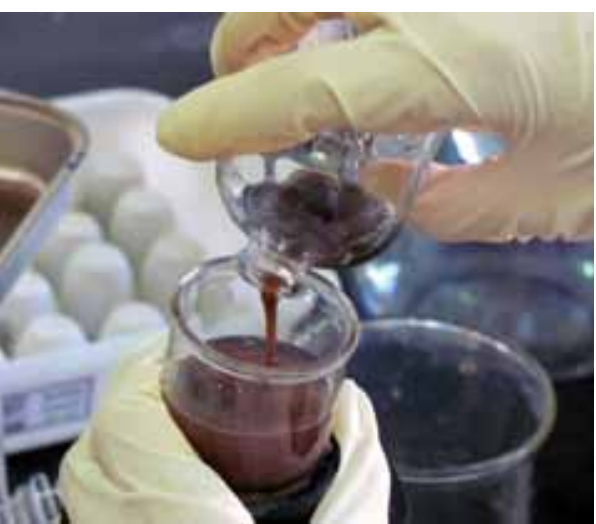

Holocellulose content analysis on eucalyptus (c) R. Quinhones/UFLA

The aim is to produce charcoal on an industrial scale that satisfies its end users' requirements. This means mastering pyrolysis conditions, taking account of the initial characteristics of the raw materials used, and making optimum use of co-products. The challenge is also to demonstrate the feasibility of an industrial-scale biorefinery. Brazil, the world's leading charcoal producer for its steel-making sector, is a life-size model of vital importance.

A continuous industrial pilot, called Carboval, was built in 2008 by the V\&M Florestal company, based on a process used successfully by H\&R Ingénierie in France. It covers every stage, from cutting and drying logs to electricity and heat generation. The pyrolysis conditions required to achieve the relevant specifications for plant charcoal for use in blast furnaces (granulometry, fixed carbon) have been defined, and the process is currently being optimized.

\section{From laboratory sample to industrial pilot}

Researchers have also carried out laboratory analyses of the effect of the chemical composition and mechanical properties of eucalyptus on charcoal. The results show moderate variations in holocellulose, lignin and extractant contents, at the tree level and between species. The mechanical properties of eucalyptus, on the other hand, vary significantly, particularly in terms of resistance to longitudinal compression. After pyrolysis, these variations are seen in the charcoal produced. It is worth noting that resistance to compression initially decreases with temperature, until it reaches a minimum, and subsequently increases steadily at high temperatures, which suggests that the carbon structure is modified above a given temperature.

The value of these results lies in their direct application, with a view to both selecting raw materials and controlling product properties. For instance, the granulometric, chemical and mechanical properties of charcoal have a direct impact on furnace operations and yields and on greenhouse gas emissions. The originality of these studies lies in the many scales covered, from laboratory sample to industrial pilot, with a view to understanding the relations between raw material and end product, and to controlling scale effects during pyrolysis.

Contact > Alfredo Napoli, Production and Processing of Tropical Woods

\section{FORFURTHERINFORMATION}

Da Silva R., 2009. Propriedade mecanicas da madeira de clones de Eucalyptus e do carvão produzido entre $350{ }^{\circ} \mathrm{C}$ e $900{ }^{\circ} \mathrm{C}$. Thesis, Federal University of Lavras.

Quinhones R. et al., 2009. Assessment of the Eucalyptus wood basic density using strength to the perforation of the stem as predictor. In: World Forest Congress, 18-23 October 2009, Buenos Aires, Argentina.

Vieira R.S. et al., 2009. Effect of the mechanical properties of Eucalyptus maculata and Eucalyptus microcorys on charcoal production. In: World Forest Congress, 18-23 October 2009, Buenos Aires, Argentina.

Managing the

\section{sustainable fuelwood resource}

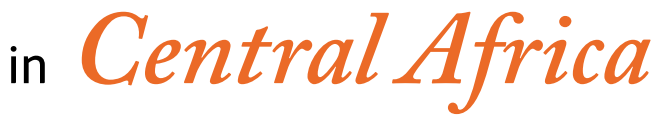

In Central Africa, fuelwood accounts for $80 \%$ of the wood taken from forests, and covers the major part of domestic energy consumption. This is now a major cause of forest degradation, particularly in periurban areas and urban supply areas. How can we ensure sustainable fuelwood supplies to towns while limiting the environmental impact in terms of forest degradation and deforestation? This is the question the EU-funded Makala project, which began recently in the Democratic Republic of Congo and is scheduled to run for four years, is aiming to answer.

The first stage consists in analysing fuelwood and charcoal transport flows for Kinshasa and Kisangani, so as to determine the origin of the wood and assess the volumes involved. The next step will be to replant to compensate for the volumes lost. In grassland savannas, priority will be given to Acacia sp., a species popular with local people. In very degraded forests, the aim will be to replant local forest species.

In the field, all the operations will involve local communities, which will make it possible to work on land tenure security, a vital issue for rural development, and to guarantee farmers a fair return on their long-term investment. Lastly, new methods are to be tested, to improve wood processing to make charcoal and to improve energy efficiency.

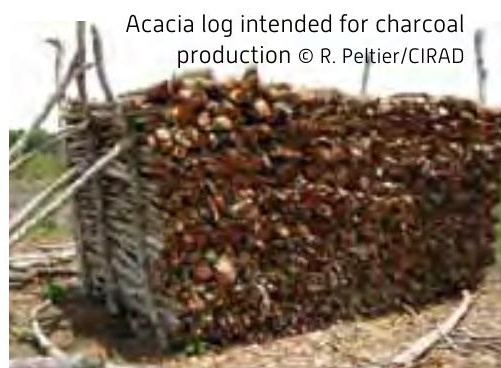

\section{PARTNERS}

Centre for

International Forest Research (CIFOR), Regional School for Integrated Tropical Forest Management (ERAIFT,

Democratic Republic of Congo), Faculty of Agricultural

Science, Gembloux (Belgium), Hanns

Seidel Foundation (Germany), Ministry of Forest Economy (Congo), Ministry of Environment, Nature Conservation and Tourism (Democratic Republic of Congo),

Royal Museum for Central Africa (Belgium), University of Kisangani

(Democratic Republic of Congo), European Union

Contact > Jean-Noël Marien, Tropical Forest Goods and Ecosystem Services

FORFURTHER INFORMATION

Bisiaux F., Peltier R., Muliélé J.C., 2009. Plantations industrielles et agroforesterie au service des populations des plateaux Batéké, Mampu, en République démocratique du Congo. Bois et forêts des tropiques, 301: 21-32.

Marien J.N., 2009. Forêts périurbaines et bois énergie: quels enjeux pour l'Afrique centrale ? In: Etat des forêts 2008. COMIFAC, OFAC p. 213-230. 


\title{
from biomass
}

\section{in Madagascar}

\begin{abstract}
Most of the people living in rural areas in Madagascar have no chance of being connected to the National Grid. However, they do have biomass resources that could be used to fuel decentralized electricitygenerating plants. The Bioénergélec project that CIRAD has just launched with its partners in Madagascar and with EU support is intended to equip six towns with such plants.
\end{abstract}

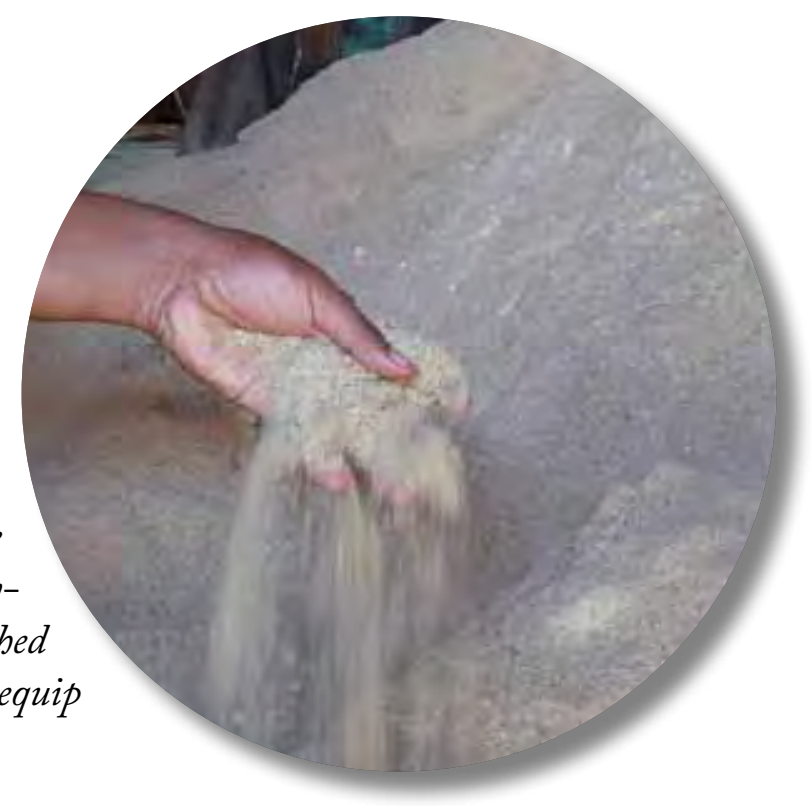

Rice husk in the town of Ambohijanahory @ Bioénergélec project

$\mathrm{M}$ ore than $70 \%$ of people in rural areas of Madagascar are isolated and have no chance of being connected to the National Grid in the near future. However, the country does have considerable biomass resources that could be used to produce electricity by setting up decentralized electricity supply networks. This type of electricity production, which costs ten times less than diesel-fired power generators, would help create economic opportunities downstream, such as shelling and crafts, and also upstream, to ensure biomass man- agement, collection and transport to production sites.

However, it does require significant investment: around 75000 euros to install a cogeneration unit-steam generator, boiler and electricity generator-with an expected lifespan of around 20 years. A nearby water source and regular biomass supplies are also needed.

Six towns, totalling just under 30000 inhabitants, are due to be equipped with this type of plant under the Bioénergélec project.
Participation

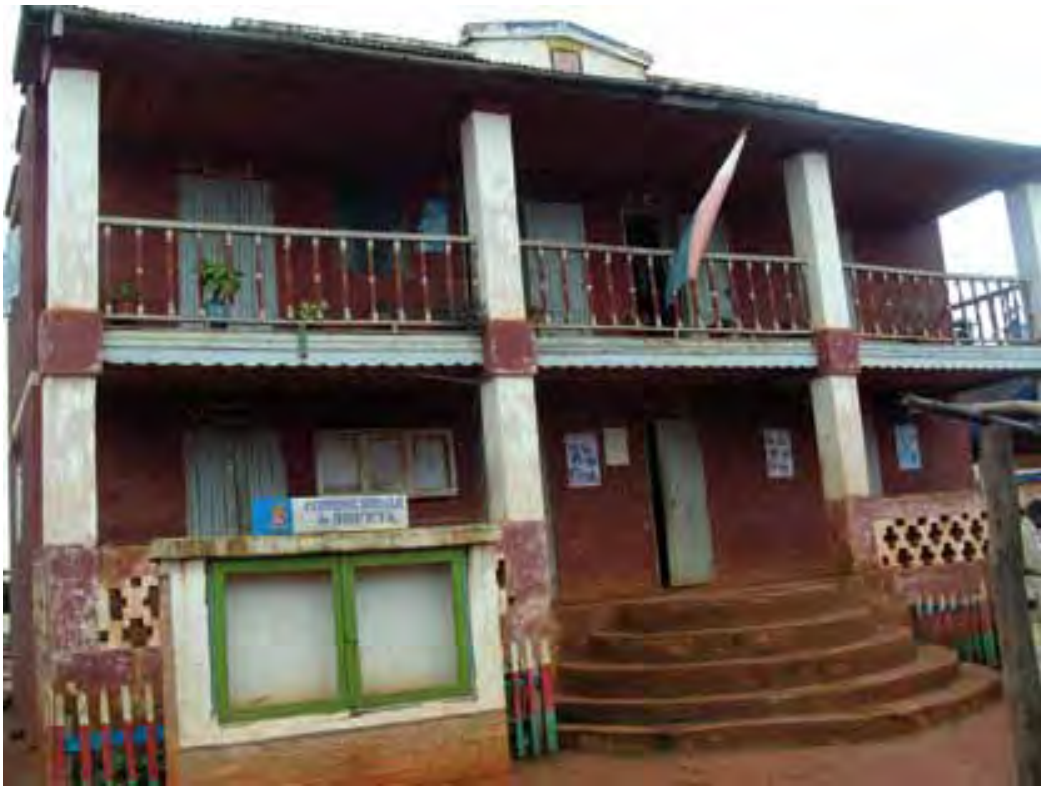

PARTNERS

Agence pour le développement de l'électrification rurale (ADER,

Madagascar),

National Centre for Applied Research on Rural Development (FOFIFA,

Madagascar), Centre wallon de recherches agronomiques (CRA-W, Belgique), à la gestion de l'environnement (Partage,

Madagascar), European Union (Europ Aid Energy Facility)

www.bioenergelec.eu

They were selected on the basis of an assessment of the amounts of biomass and water available and their estimated energy requirements, in four regions: Boeny in the west, Alaotra-Mangoro in the East, Haute-Matsiaka in the centre and Anosy in the Southeast. The selection was approved in September 2009 in Antananarivo, in the presence of the regional and local authorities concerned. An international call for tender will be issued to choose the consortium that will provide and install the six cogeneration plants, five medium- and low-voltage electricity distribution networks, infrastructures and buildings, and related training and monitoring services.

CIRAD is in charge of the work to be done prior to setting up the cogeneration plants, notably establishing the legal framework. It is also conducting a survey to determine the impact of such operations on poverty alleviation and local economic development, which should concern some 5000 households.

Town of Befete, Haute-Matsiaka (c) Bioénergélec project
Contact > Pierre Montagne, Tropical Forest Goods and Ecosystem Services 


\section{Biofuels}

\section{for professional fisheries}

Since the 1990s, developing countries have been trying to become less dependent on oil-based fuels, the price of which is constantly rising. CIRAD, which already has experience of using biofuels in agro-industrial engines in the agricultural and transport sectors, is currently looking into whether they could be used to power the diesel engines installed in fishing boats. It has just launched a study of the possibilities of adding pure vegetable oils of semi-artisanal quality to the fuels already used.

$\mathrm{M}$ any developing countries are keen to have fuels produced in a short circuit to replace diesel. The aim is to produce biofuels of plant origin locally, of sufficient quality to power engines located a few kilometres from where the oil is produced. The fuels in question are pure vegetable oils. For professional fishing operations, the fuels need to satisfy requirements linked to the safety of the people operating the boats, who cannot risk having the engine break down.

Before extending the practice of using such biofuels in boats in developing countries, studies are required to determine whether engines fuelled with semi-artisanal quality oils are both reliable and long-lasting. This was the task set for two research programmes headed by CIRAD: the Itsasoa operation, launched on the west coast of France with two working fishing boats, and a study of the possibilities of using various types of biofuels, such as seaweed oils, to part-fuel modern engines. This work concerns engines with a power of less than $300 \mathrm{~kW}$, which are the most commonly used in developing countries and also the easiest to fuel with pure biofuels such as vegetable oils.

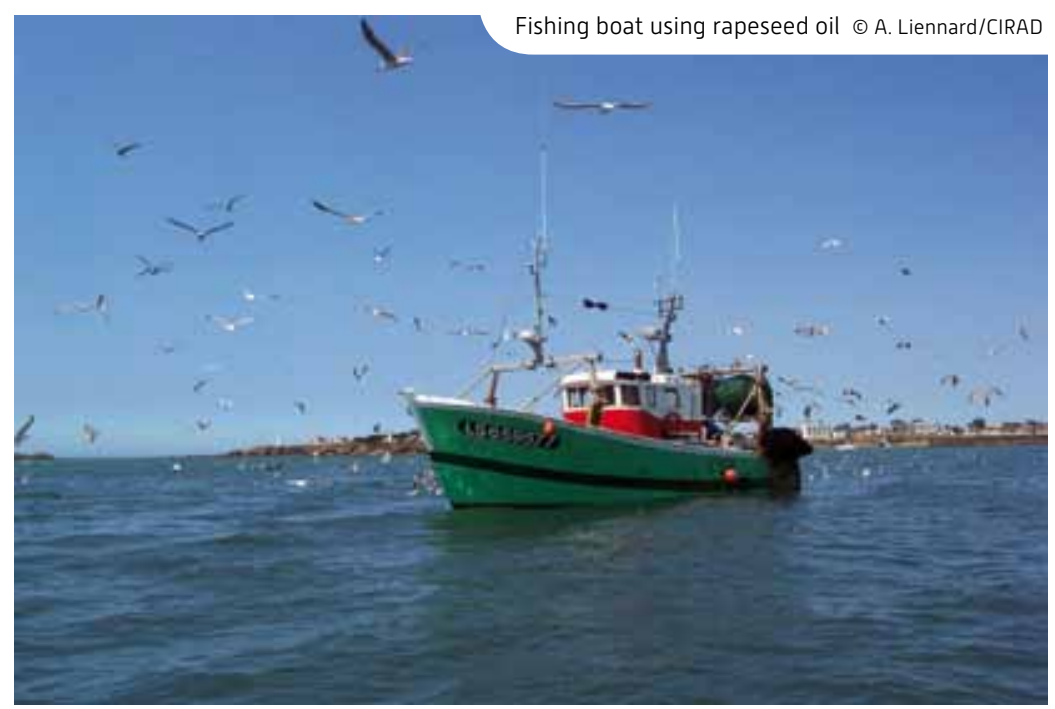

PARTNERS

Maritime Affairs, Comité national des pêches maritimes et des élevages marins (CNPMEM),

European Fisheries Fund, Institut français des huiles végétales pures (IFHVP), Institut français de recherche pour l'exploitation de la mer (IFREMER), Ministry of Food, Agriculture and Fisheries
If this new mode of propulsion proves reliable, an economic evaluation will be carried out, taking account of the amounts of $\mathrm{CO}_{2}$ avoided. The study will disassociate the price of the fuel oil from global oil or seed prices, and from the unpredictable price of diesel. The scenario behind the operation centres on using 10 to $15 \%$ of the total oilseed harvest to produce energy for production machinery and boats, the aim being to ensure local and regional self-sufficiency and provide jobs.

For the time being, this research centres on rapeseed and sunflower oil, but future trials in developing countries will concern copra, cottonseed and physic nut oil, and biofuels of animal origin, particularly fishery waste. The work done on combustion of these products by CIRAD in the past should be a real asset to future studies.

Contact > Alain Liennard, Biomass and Energy 


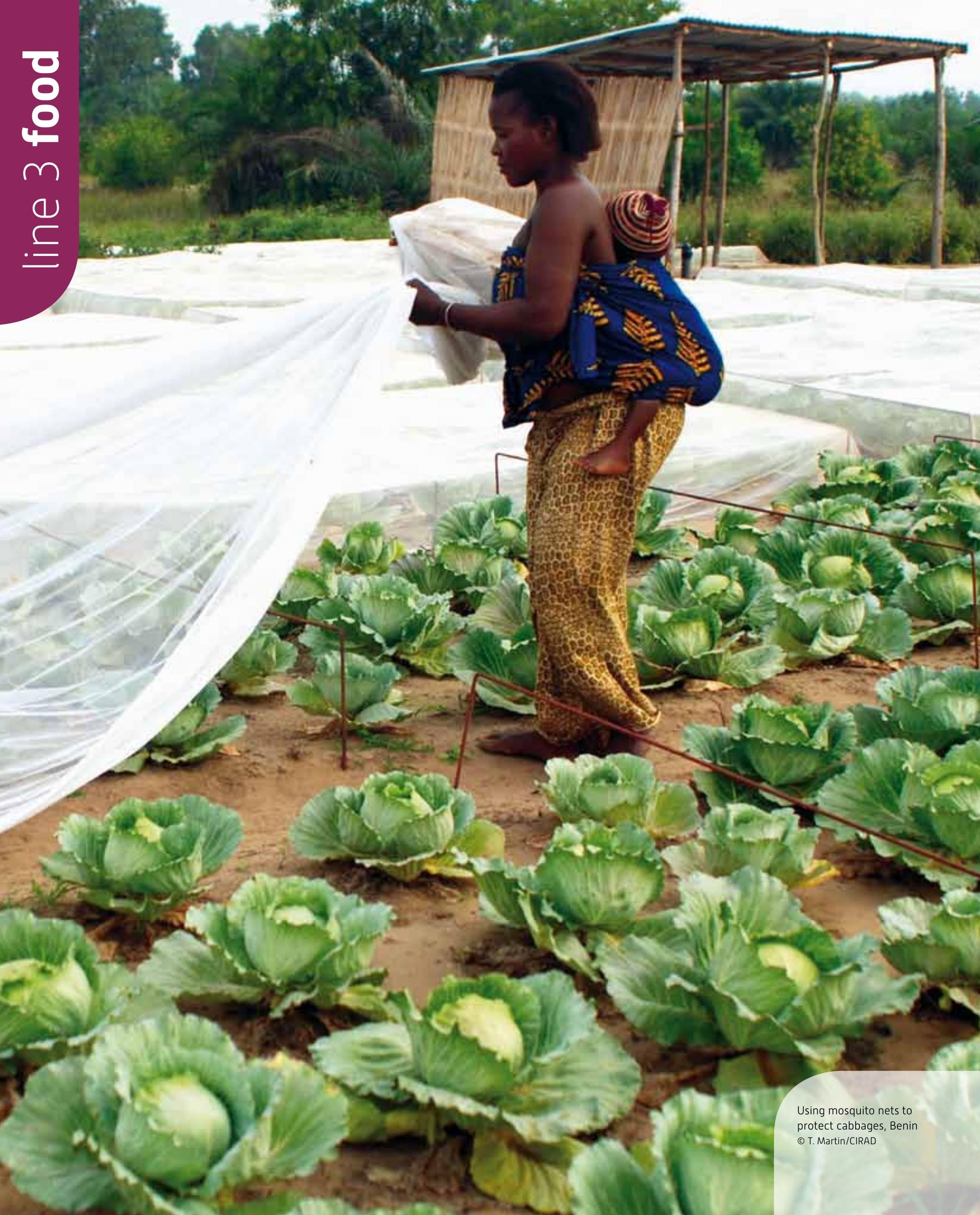




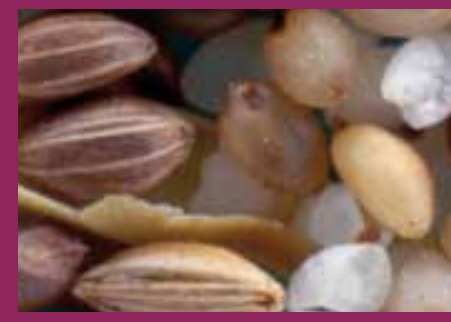

page 38

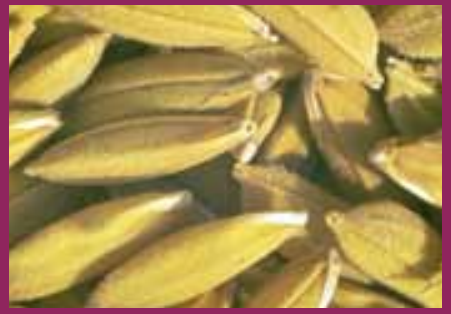

page 40

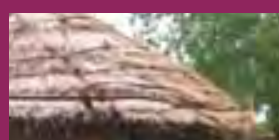

page 41

\section{Regional platforms}

The food crises that have hit people in developing countries, along with "food riots", are not strictly linked to shortages, but rather to the problem of access to food resources. CIRAD is supporting the indepth changes currently being made in the sector, notably four regional structures: two in Cameroon (PCP Grand Sud Cameroun in an agroforest zone, and CARBAP for banana- and plantainbased systems), one in Asia (MALICA), more specific to urban markets and supplies, and one in the Maghreb (RCP SIRMA) centring on sustainable water management. In Réunion, there is a regional platform working on agricultural and food product quality.

\section{Ethics Committee} and foresight

Nowadays, each and every country is concerned by food insecurity and poverty. It was this topic, and that of food habits, that were covered by the first statement issued by the INRA-CIRAD Common Advisory Committee for Ethics in Agricultural Research. The Committee calls upon researchers to remain vigilant, particularly in terms of the diversity of food habits and the nutritional requirements of the least favoured groups. It stresses the need to involve players in the different stages of the research process, and recommends supporting plans for a debate on their economic and ecological impact and on the means of reducing waste. Lastly, it calls for a debate on public food policy within every research project.

Feeding the world while ensuring sustainable development is not an impossible task, but the challenge does need to be understood and anticipated: it requires a strong commitment on the part of the research sector. To mark World Food Day in October 2009, at a conference, INRA President Marion Guillou and CIRAD Director General Gérard Matheron introduced and led the debate on

the results of the Agrimonde foresight study, a tool for collective reflection on global food and agricultural issues between now and 2050 .

\section{Geographical indications}

Geographical indications are now a global issue. They are of strategic importance in trade talks, particularly in view of the recent food crises. In effect, they can help in the development of commercial food crops, in confirming agricultural and food know-how, in securing food supplies to rural areas, and in alleviating poverty. Developing geographical indications for tropical and Mediterranean products is an ambition that CIRAD and INAO have shared since 2003. To step up their collaboration, the two organizations

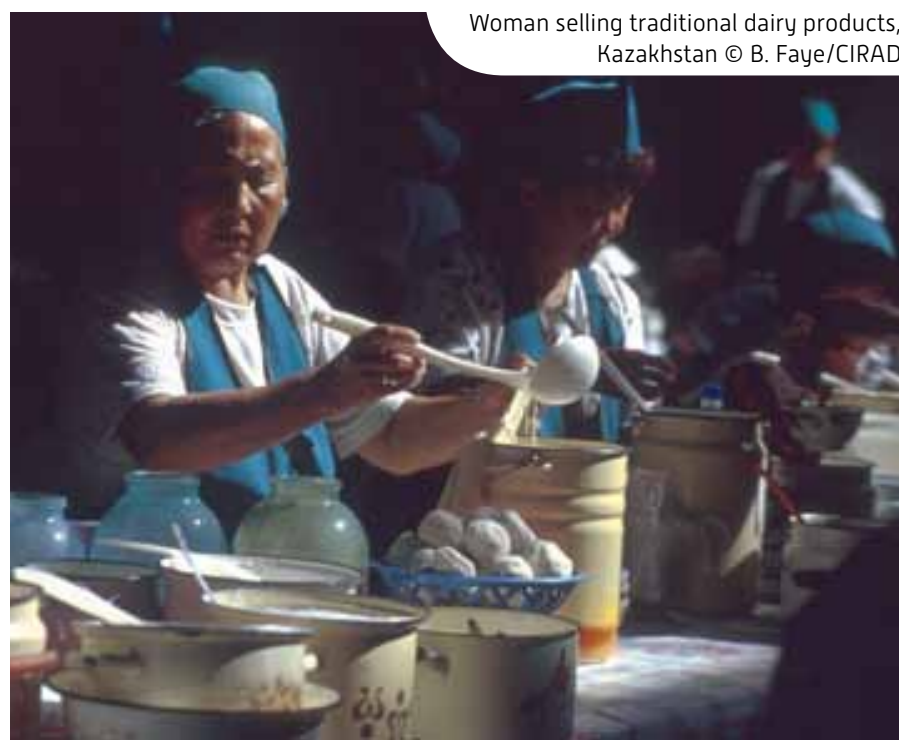

signed a new agreement in 2009 that aims in particular to better assess the merits of the notion of geographical indications. Avoiding the misuse of names linked to the history and heritage of countries is now an issue in international talks. Identifying those names and capitalizing on this heritage is a major objective for collaborative operations with developing and emerging countries.

\section{Training}

In terms of training, CIRAD is involved in numerous Masters courses in France and overseas, on food, processing and nutrition. It plays a particularly active part in training engineers in the agrifood industry in hot regions (IAARC), and is a partner in several Masters courses such as the $3 \mathrm{~A}$ Science and Technology Masters and the Masters in Rural Development Players in Hot Regions with Montpellier SupAgro. CIRAD is also involved in Masters degrees awarded by the University of Montpellier 2, such as the "Animal Production in Developing Countries: Environment and Development" module of the Masters in Biology, Geosciences, Agroresources and Environment awarded by the University of Montpellier 2. 
Fonio is the oldest cereal in West Africa. It is grown from Senegal to Lake Chad. Until recently, the fact that processing operations were smallscale, time-consuming and difficult meant that there was no future for the crop. However, following work by CIRAD and its partners on mechanizing hulling operations and modernizing drying, there is renewed interest in fonio and new export chains are developing around innovative products.

Conio (Digitaria exilis) is a tiny 1 grain from West Africa. The total crop amounts to around 360000 tonnes for 450000 hectares planted. The average yield is $800 \mathrm{~kg}$ per hectare: it can be up to a tonne in Guinea, which alone accounts for more than $60 \%$ of the total produced, but does not exceed $500 \mathrm{~kg}$ in some northern areas of Burkina Faso and

Mali.

This small herbaceous plant, which grows to a height of 30 to $80 \mathrm{~cm}$, is grown on light, sandy or stony soils, and can withstand poor soils and low-quality land. It is highly rustic, and resists both drought and heavy rain. Depending on the variety, the crop cycle takes from 70 to 150 days, and very short-cycle varieties ensure early
PARTNERS

Centre international de recherche-

développement sur l'élevage en zone subhumide (CIRDES, Burkina Faso), Centre wallon de recherches agronomiques (CRA-W, Belgium), Groupe recherches actions formations (ENDA-GRAF, Senegal), Institut d'économie rurale (IER, Mali), Institut de recherche agronomique de Guinée (IRAG, Guinea), European Union, University of Wageningen (Netherlands)

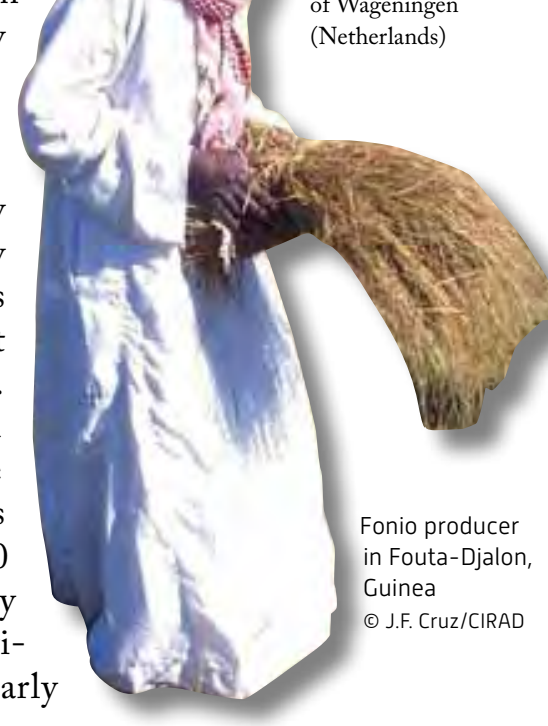

\section{Fonio,}

the rediscovery of a traditional cereal harvests that serve to bridge the "hunger gap".

Fonio, which was long seen as the "poor man's cereal", is now the object of renewed interest among urban consumers due to its taste and nutritional qualities. It has a similar composition to that of white rice. Overall, it contains less protein than other cereals, but is reputed for its high sulphur amino acid content. In Africa, it is traditionally eaten as couscous or in gruel, and is often recommended for the sick, the overweight and pregnant women.

\section{Long, complex, small-scale processing operations}

Like rice, fonio has to be hulled to remove the husk, and then whitened to remove the bran. These operations, which are traditionally done by women using a pestle and mortar, are particularly difficult due to the very small grain size. To obtain a quality product, the

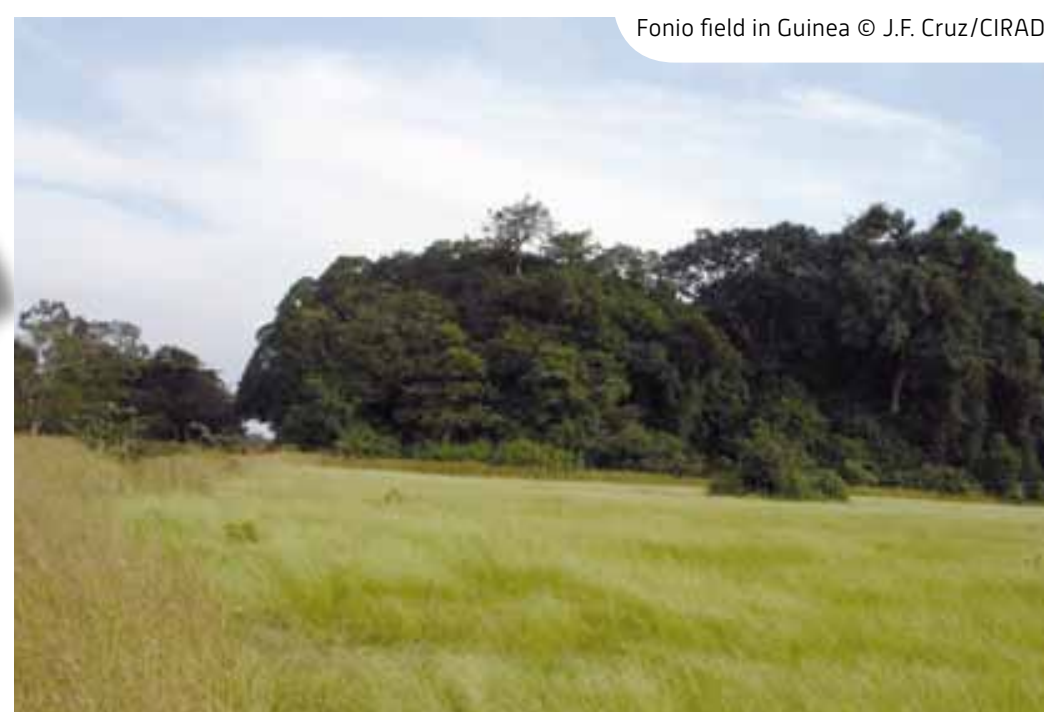



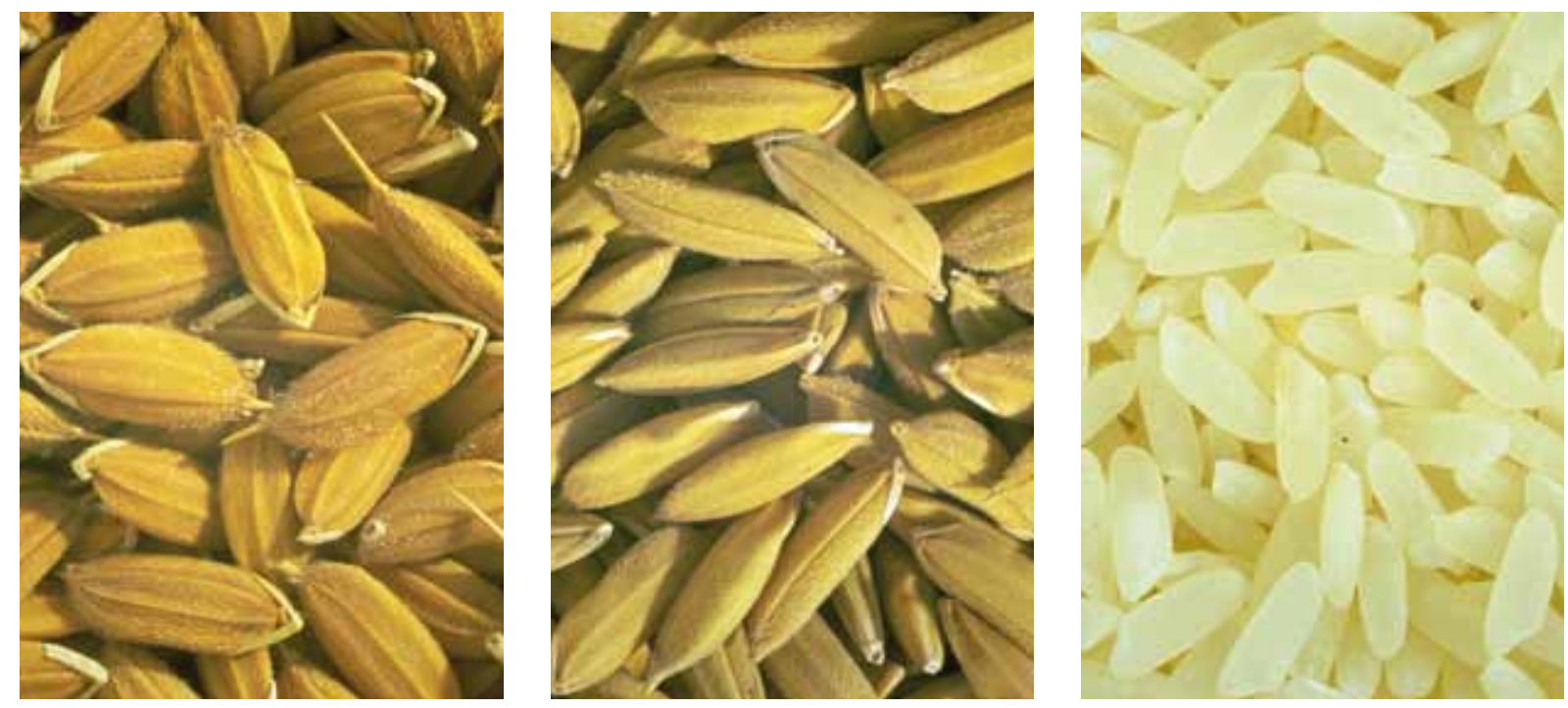

\section{Camargue aromatic rice}

\section{Aromatic rice currently accounts for almost 30\% of the French rice market. Two} varieties, Basmati and Thai, which are imported from Asia, have monopolized the market, and the aromatic varieties bred for the Camargue region are finding it hard to compete. But what makes aromatic rice different from other types? And what determines its aroma?

S everal compounds can contribute to rice aroma. Some form during storage and others during cooking, notably as a result of fat oxidation. However, one particular compound, 2-acetyl-1-pyrroline (2AP), stands out: this is what gives cooked rice its typical popcorn aroma.

Expression of the genes governing biosynthesis of this compound is strongly affected by the agroenvironmental conditions in which the rice is grown. CIRAD researchers thus embarked upon an in-depth characterization of the aromatic composition of cooked rice, comparing aromatic varieties from Camargue with international standard types, and an assessment of the effect of salt stress on 2AP biosynthesis in rice grains and green organs.

\section{Cooked rice aroma}

Generally speaking, the aroma of cooked rice, assessed by gas chromatography-olfactometry or by calculating odour units, is characterized by the presence of $2 \mathrm{AP}$, on the one hand, and of some sixty other aroma compounds on the other. Most of these compounds result from fat breakdown, but some stem from cinnamic acid breakdown. Nonaromatic rice is primarily distinguished by its low 2AP content, although the level is sufficient to be seen clearly in a chromatograph.

Cooking drastically changes the aromatic composition of rice: it causes a $25 \%$ increase in the number of aroma compounds, but results in significant losses of
2AP (around 70\%) and aldehydes, the main factors in rice aroma.

The varieties from Camargue appear to be richer in $p$-coumaric acid and linoleic acid, the precursors of 4-vinylphenol and $(E, E)$ and $(E, Z)$-deca-2,4-dienal. These two volatile compounds are found in cooked rice from Camargue in particular, and seem to make a significant contribution to the aroma of those varieties. Moreover, the Camargue variety Aychade is equivalent to world standard varieties, albeit with a slight specificity: a high 2AP content, a quite different fat oxidation compound content and specific "floral/grassy" and "fruity/strawberry" notes resulting from $g$-heptalactone and an unknown compound.
PARTNERS

Centre français du riz, Ecole nationale supérieure de chimie de Montpellier, Institut national de la recherche agronomique (INRA),

Office national interprofessionnel des grandes cultures (ONIGC), LanguedocRoussillon Regional Council, Biosens company, University of Montpellier 2 


\section{Aroma}

\section{and salt stress}

A new 2AP quantification method, by stable isotopic dilution, has been developed. It uses deuterated 2AP as an internal standard and mass spectrometry in chemical ionization and in tandem mode as the quantification method. This makes it specific, reproducible and sensitive. The method was used in this study to detect the presence of 2AP in the grains of a non-aromatic variety and to show that the leaves are the organs that contain the most 2AP. It could be used routinely for studies of 2AP biosynthesis and for comparing rice varieties.

These studies revealed that salt stress results in increased 2AP contents in the grains and leaves, particularly during panicle initiation and flowering, along with increased levels of proline, one of the precursors of $2 \mathrm{AP}$, in the leaves. The amount of $2 \mathrm{AP}$ in the grains increases if salinity is high before flowering. This phenomenon may result from transport of the $2 \mathrm{AP}$ produced in the leaves of stressed plants or from 2AP synthesis in the grains from the proline that builds up in the leaves and is transported to the grains.

Contacts > Isabelle Maraval, Christian Mestres, Integrated Approach to Food Quality [QUALISUD]

\section{FORFURTHERINFORMATION}

Gay F. et al., 2010. Effect of salinity on yield and 2-acetyl-1-pyrroline content in the grains of three fragrant rice cultivars (Oryza sativa L.) in Camargue (France). Field Crops Research, 117 (1): 154-160.

Maraval I. et al., 2008. Odor-active compounds in cooked rice cultivars from Camargue (France) analysed by GC-O and GC-MS. Journal of Agricultural and Food Chemistry, 56: 5291-5298.

Maraval I. et al., 2008. The odor of cooked rice: Identification and origin of odor active compounds. In: 2008 AACC International Annual Meeting, Honolulu, 21-24 September 2008.

\section{Food security:}

combining tools

to stabilize prices

The 2007-2008 food crisis put instability right back at the heart of the debate. However, it is not enough to manage the risks resulting from that instability by calling upon futures markets and food aid. A degree of price stabilization is required, and to this end, state intervention is essential. This was the conclusion of a study coordinated by CIRAD, which goes against the principles defended even recently by some economists.

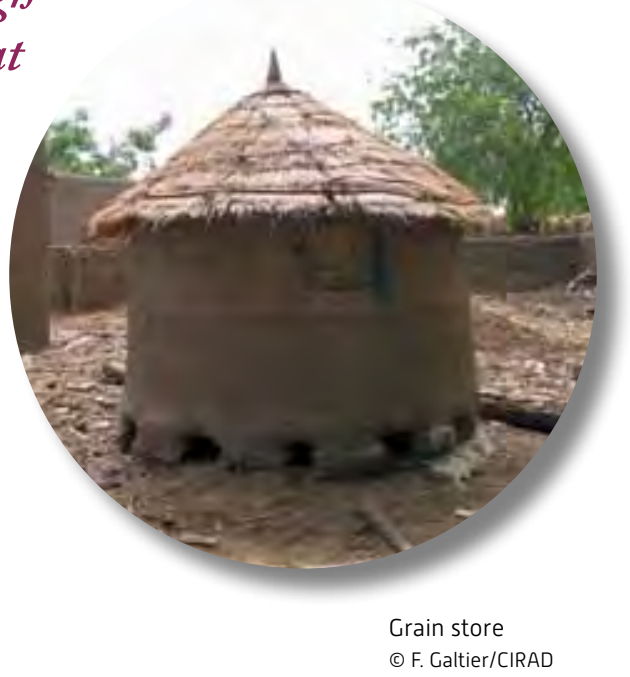

Since the agricultural liberaliza-

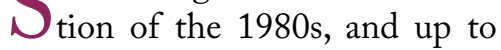
the 2008 crisis, most economists had thought that price instability was not a problem. Enabling producers, traders and consumers to protect themselves against the risks resulting from that instability was considered sufficient. Experts recommended private risk management mechanisms, such as futures markets or crop insurance, or public mechanisms such as food aid or measures aimed at protecting the most vulnerable households. This failed in two ways: in developing countries, private mechanisms failed to develop, at least for cereals and staple foods; as for public mechanisms centring on the management of food crises, they failed to halt the deterioration of the nutritional situation of poor households.

\section{Mechanisms to control instability}

A study coordinated by CIRAD revealed that not only is it necessary to stabilize prices, but that stabilization is impossible without state intervention. The study suggested classifying mechanisms in four categories, depending on their aim—stabilizing prices or reducing the consequences of price instability-and the type of governance used-through markets or by means of public mechanisms. Over the past 25 years, only mechanisms aimed at reducing the consequences of instability have been seen as legitimate. Researchers

\section{PARTNERS}

Agence française de développement (AFD), Institut de recherches et d'applications des méthodes de développement (IRAM), Ministry of Foreign Affairs, Natural Resources Institute (NRI,

United Kingdom),

University of

Wageningen

(Netherlands) 
have now shown that it is necessary to make use of two other types of tools that serve to stabilize prices, either by improving market performance or through public intervention. Moreover, they affirm that these four categories of tools are not mutually exclusive, and indeed should be used in combination, depending on the causes of the instability.

In another novelty, the researchers have proposed a typology of the causes of instability. Instability may be of "natural" origin, for instance when it is caused by climatic hazards or pest attacks. However, in developing countries, it can also be "imported" from the international markets or be "endogenous", i.e. produced by the functioning of the national markets . In particular, the 20072008 crisis revealed the importance of imported and endogenous instability, which had previously largely been overlooked. Experts now agree that imported instability is likely to increase significantly in the coming years, notably because of lower stock levels than in recent years.
On a national or regional level, the aim is to introduce border controls so as to compensate for the effect of international price variations. If the instability is endogenous, public intervention may be necessary to dampen market speculation. That intervention may involve regulating markets, making use of the international market, or using public stocks. Lastly, if the price instability has natural causes, the solution is to tackle the problem at the root by modernizing food production and trade structures. However, modernization is necessarily a long-term operation. Moreover, it calls for a degree of price stabilization beforehand, since modernizing farms and markets is reliant on investment by producers and traders, who are reluctant to invest when prices are very unstable. This prior price stabilization thus means using fastacting tools such as public stocks or border controls.
To be effective, public price stabilization policy has to be realistic, transparent and credible. A sufficiently broad and flexible price range has to be defined, corresponding to state intervention thresholds. These "intervention prices" must be announced, credible and respected, otherwise public intervention may increase, rather than reduce, uncertainty among market operators.

\section{Contact > Franck Galtier, Markets, Organizations, Institutions and Stakeholders' Strategies [MOISA]}

\section{FORFURTHERINFORMATION}

Bricas N., Daviron B., Galtier F., 2009. Marchés alimentaires : à quelles échelles gérer l'instabilité accrue des prix ? Demeter, 2010: 11-53.

Galtier F., 2009. The need for public intervention to stabilize prices. CIRAD, Perspective, no. 2, 4 p. www.cirad.fr/content/download/3827/30905/ version/3/file/Perspective2_Galtier_eng.pdf

Galtier F., 2009. Comment gérer l'instabilité des prix alimentaires dans les pays en développement? MOISA Working Paper no. 4, 28 p.

www1.montpellier.inra.fr/bartoli/moisa/bartoli/ download/moisa2009_pdf/WP_4_2009.pdf

\section{Practical solutions}

In that case, how can prices be stabilized in order to secure producers' and traders' incomes and encourage the necessary investment in modernizing production and markets? For the researchers involved in the study, the answer depends on the type of instability. If it is imported from the international markets, state intervention is essential. On a global level, stabilizing prices means regulating international markets. 


\section{What is the}

\section{environmental impact of food products?}

Of all human activities, food production is the one that has the greatest impact on the environment. Moreover, it will have to increase by 57 to 100\% between now and 2050. CIRAD has committed itself to a study of the impact of products from tropical zones, based on an international procedure: life cycle analysis.

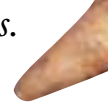

U Tnderstanding, and if possible quantifying, the effects of our production and consumption methods on the environment is now vital. France recently committed itself to environmental labelling of each and every product sold in supermarkets. Within this framework, environmental assessment of foods, be they produced in France or elsewhere, has to be as consistent as possible.

The life cycle analysis (LCA) method is an international reference in this field. It is covered by an ISO standard, which makes it possible to conduct a global assessment of the functions necessary to man. This strong conceptual framework encompasses the

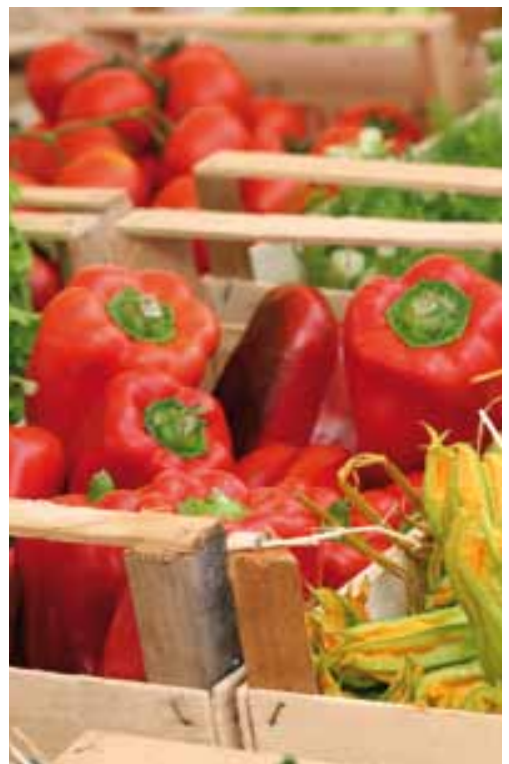

notions of function, function life cycle and multi-criteria assessments and serves, for example, to reveal possible pollution transfers between two stages in the life cycle of a product or between two environmental impacts. However, its use for agricultural and food production systems is particularly complex, and it is even more difficult to transpose to a tropical context, due to the lack of data on such systems and the gaps in our fundamental knowledge of their interactions with the environment.

Given the lack of data and the extreme variability of the systems concerned, how can we define, design and describe typical, representative farming and food

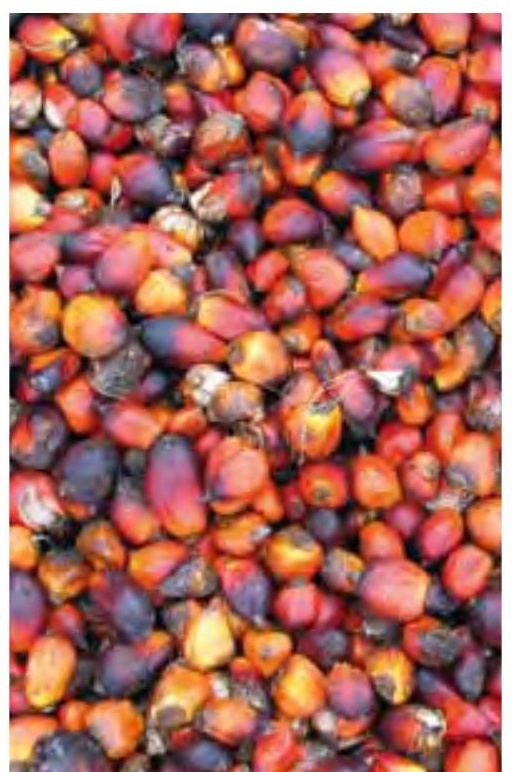

systems on a given scale? Draw up reliable environmental inventories? Adapt environmental impact characterization models to tropical conditions? What indicators are there for vitally important but often overlooked impact categories such as biodiversity, water use, soil quality or landscapes? How can we take into account and quantify the uncertainty surrounding LCA results in the event of a lack of data and measurements?

CIRAD's work on global environmental assessment of foods, with the development of life cycle analysis models, has begun with leading products, such as tomatoes, citrus fruits, oil palm, rice, animal products, and cassava. It involves identifying methodological questions specific to the fields of application concerned and building projects in partnership. All these projects are multidisciplinary; one of them sets out to acquire LCA references for the main supply chains and to compile a database for tropical products.

Contact > Claudine Basset-Mens, Agroecological Functioning and Performances of Horticultural Cropping Systems 


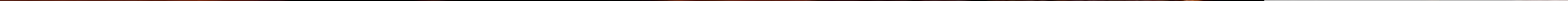




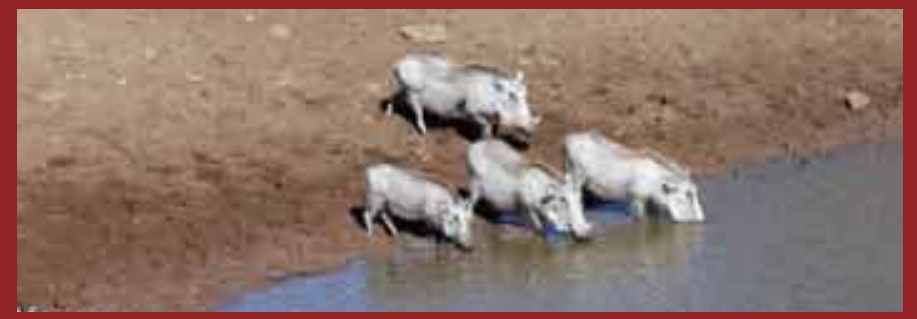

\section{Regional networks}

As part of its geographical partnership strategy, CIRAD has been strengthening and building several regional expertise networks that combine research, training and support for veterinary services and farmers.

\section{International}

\section{expertise}

On vector-borne diseases, trans-border diseases and diseases at the wildlife-livestockman interface, CIRAD has achieved recognition both for its scientific expertise and for its ability to handle large-scale projects, i.e. in coordinating the EDEN (Emerging Diseases in a changing European eNvironment) project. This recognition is essential for convincing the EC and funding agencies to invest in animal and human health in tropical countries, which is crucial for controlling emerging diseases. It relies on a recognized research network that is called upon by European and international public health agencies to provide expertise or advice on research priorities.

\section{Avian influenza}

With respect to avian influenza, the GRIPAVI project (research on the ecology and epidemiology of avian influenza and Newcastle diseases in trop- ical countries), funded by the Ministry of Foreign and European Affairs (France), integrates and coordinates six observatories in Africa and Asia for epidemiological, virological and ecological research on wild birds and domestic poultry.

\section{Higher education}

CIRAD is highly involved in university-level teaching on epidemiology and tropical livestock production. In collaboration with the University of Montpellier 2 and the Uni- versity of Kasetsart in Bangkok, CIRAD is participating in a 2-year binational Master's programme (Infections, Vector-borne and Food-borne Diseases: Bio-veterinary Sciences, MIVA), in partnership with the Institut Pasteur; with the Ecole vétérinaire d'Alfort (France), the University of Paris 11 and Paris 12, in a Master's programme on Epidemiological Surveillance of Human and Animal Diseases in Public Health; and with the Ecole nationale vétérinaire de Toulouse and the Univer- sity of Montpellier 2 (France), in a Master's programme on Animal Health and Epidemiological Surveillance in Tropical Regions. In collaboration with the Ecole vétérinaire d'Alfort, it manages a Certificate in Higher Studies (CES) in Animal Epidemiology, leading to a diploma from the Ecole nationale vétérinaire d'Alfort. In Montpellier, it is involved in two Master's programmes on animal production in hot regions (Montpellier SupAgro, University of Montpellier 2).

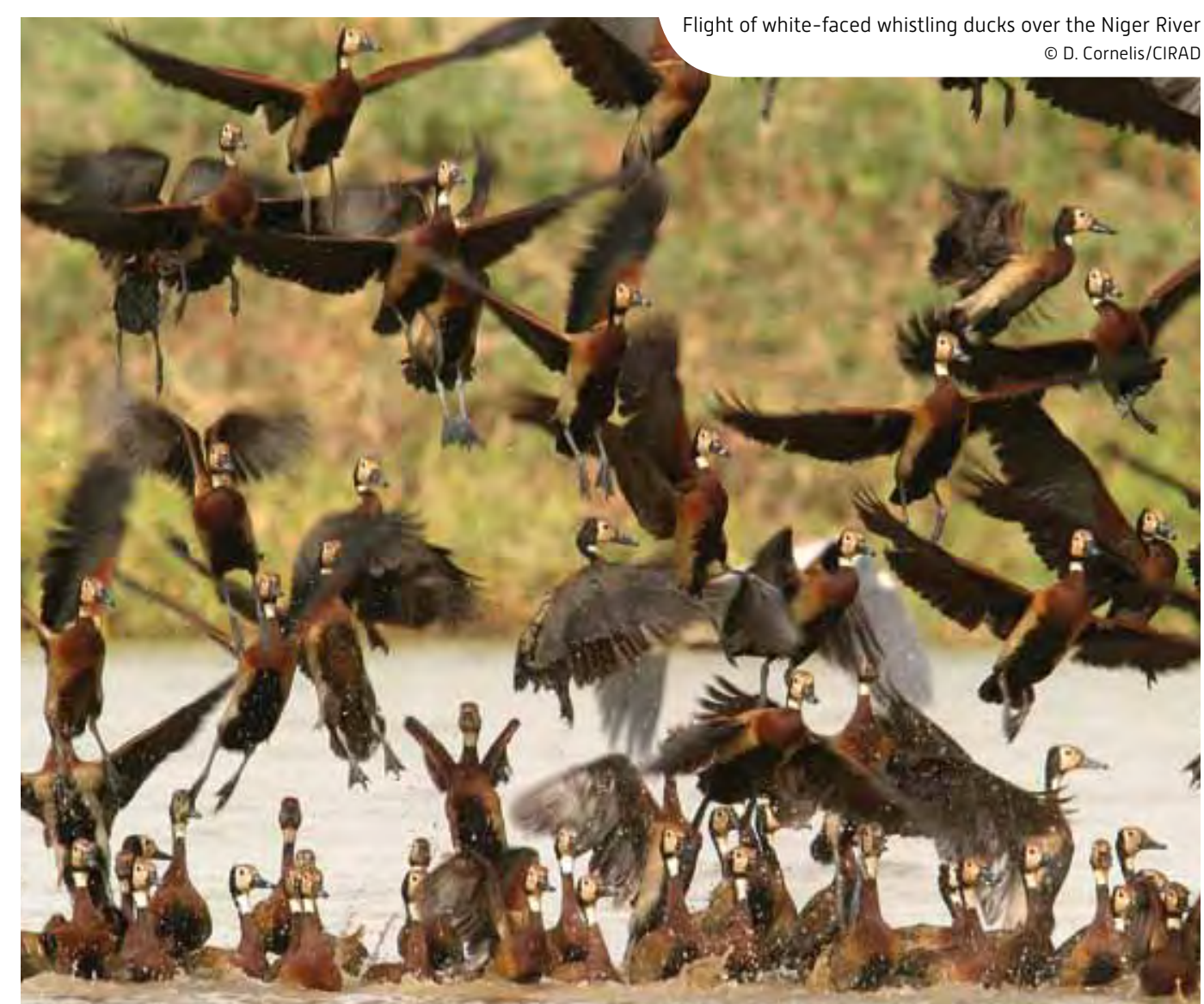




\section{An epidemiological risk management network in South-East Asia}

In South-East Asia, a combination of many ecological and socioeconomic factors has led to the development and expansion of agroecosystems conducive to the emergence and dissemination of diseases, especially avian influenza. In 2009, CIRAD created a regional cooperation in partnership network with the aim of enhancing the management of these risks. The aim of this Management of Emerging Risks in South-East Asia (GREASE) network is to gain insight into emerging diseases in this region by promoting university exchanges and pooling scientific synergies. For CIRAD and partners, this involves organizing and conducting research and training on a regional scale in order to propose appropriate health policies. Several topics will be developed in collaboration with regional OIE and FAO representatives and other

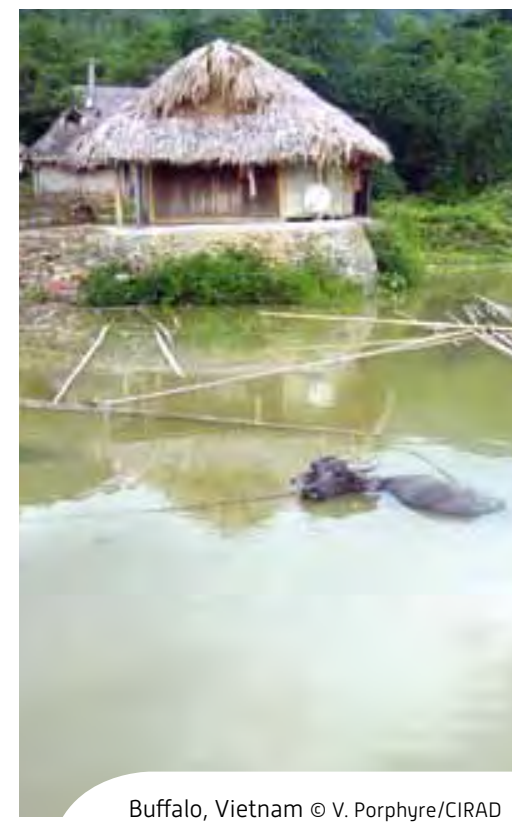

existing networks, including: ecology and health, surveillance system assessment methods (including socioeconomic aspects), animal influenza viruses, emerging diseases of suids, and the develop- ment of modelling tools based on graph theory and sociology. The network will be guided by workshops and training sessions, missions and meetings, and should ultimately extend from the southern provinces of China to the South-East Asian islands.

Contact > François Roger, Animal and Integrated Risk Management

\section{FORFURTHERINFORMATION}

Desquesnes M. et al., 2009. Antibody-Elisa for Trypanosoma evansi: application in a serological survey of dairy cattle, Thailand, and validation of a locally produced antigen. Preventive Veterinary Medicine, 90: 233-241

Paul M. et al., 2009. Anthropogenic factors and the risk of highly pathogenic avian influenza $\mathrm{H} 5 \mathrm{~N} 1$ : prospects from a spatial-based model. Veterinary Research, 41: 28.

Tran A. et al., 2010. Remote sensing and avian influenza: A review of image processing methods for extracting key variables affecting avian influenza virus survival in water from earth observation satellites. International Journal of Applied Earth Observation and Geoinformation, 12: 1-8, Doi: 10.1016/j. jag.2009.09.014.

grease-network.com
PARTNERS

Agence française de développement

(AFD, France),

diagnostic and

veterinary research

laboratories in Hanoi (NCVD, NIVR,

Viet Nam), Direction générale de

l'alimentation (DGA

France), Food and

Agriculture

Organization of the

United Nations

(FAO), Institut

national de la

recherche

agronomique (INRA,

France), Institut

Pasteur (Cambodia),

Institut de recherche pour le

développement (IRD,

France), Murdoch

University (Australia),

national agricultural

research institutions

in South-East Asia,

University of Hanoi

(Viet Nam),

University of Hong

Kong (China),

University of

Kasetsart (Thailand),

University of Laos,

World Organization

for Animal Health

(OIE)

PARTNERS

Caribbean

Community

(CARICOM), Fonds

de coopération

régionale de

Guadeloupe, Food

and Agriculture

Organization of the

United Nations

(FAO), Inter-

American Institute

for Cooperation on

Agriculture (IICA),

Ministry of Foreign

Affairs (France), Pan

American Health

Organization

(PAHO), Région

Guadeloupe,

European Union,

United States

Department of

Agriculture (USDA),

World Organization

for Animal Health

(OIE) tributes to strengthening surveillance systems by pinpointing aspects of this network make it unique, and it is also a regional

Lefrançois T. et al, 2009. Surveillance of avian in the Caribbean through the Caribl Doi: 10.1637/8787-040109-ResNote.1. 


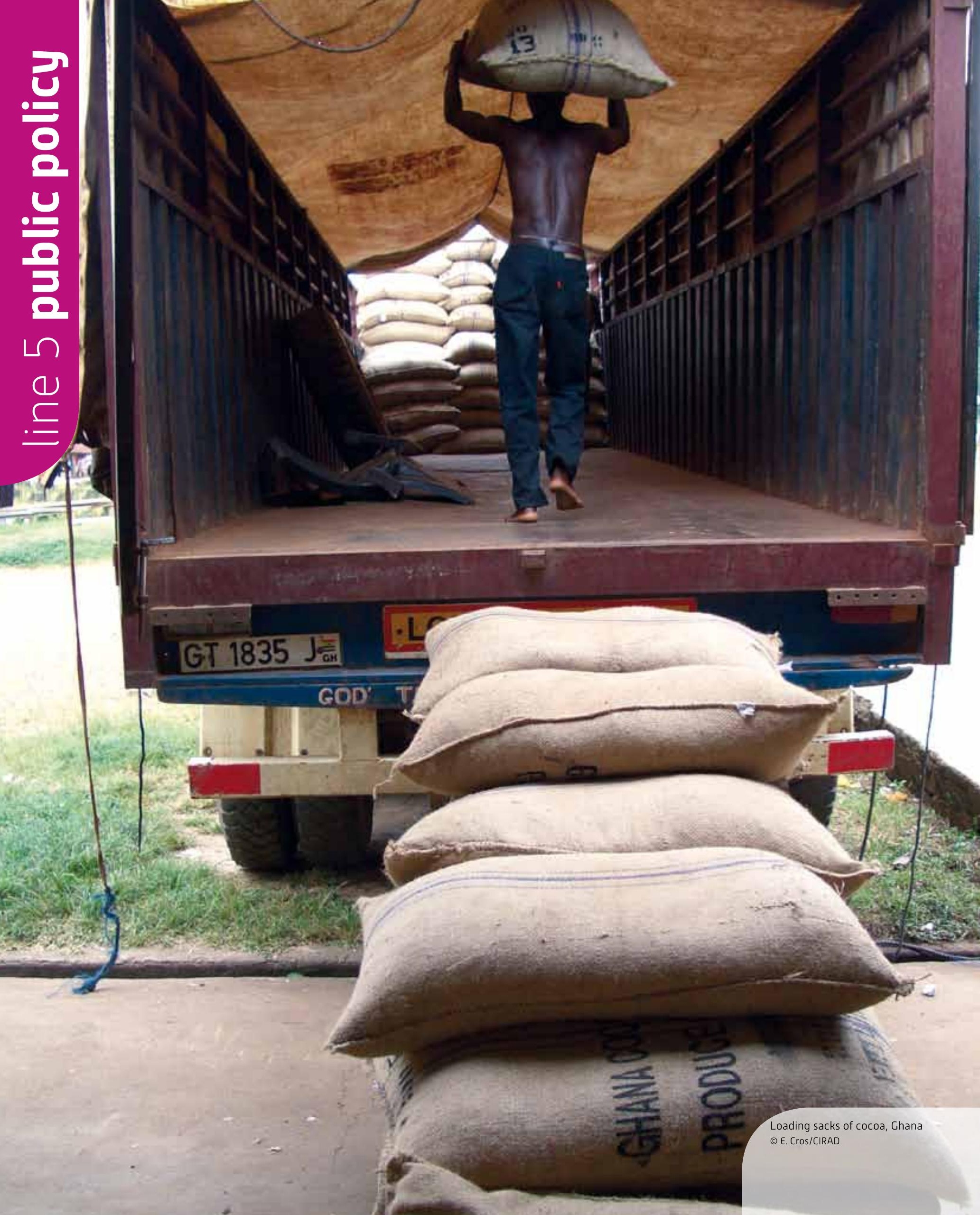



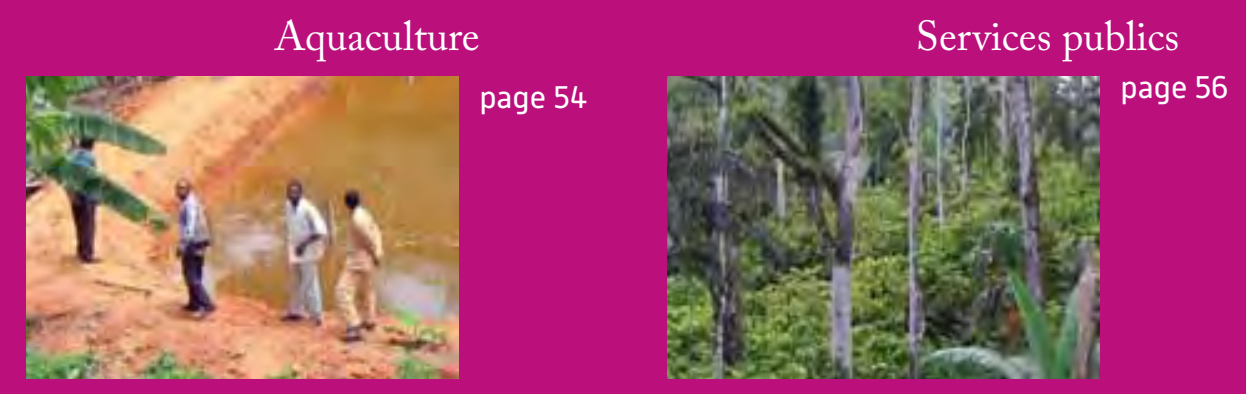

\section{Partnerships,}

to reduce inequality

Public policy can play a major role in reducing the structural inequalities that sustain poverty. It is part of the research programmes on which CIRAD and its partners are working within the framework of three priority research structures: the Congo Basin forest network, the Agroforestry research consortium in Latin America, and the SIRMA network on water management in the Maghreb.

Women smallholders' organization meeting, Madagascar $\odot$ E. Penot/CIRAD

\section{Land acquisitions}

Land appropriation processes, which are becoming more common in developing countries, are a source of concern for public opinion. In association with international institutions and several French and overseas universities and research centres, CIRAD organized a "Land Tenure Day" in Montpellier in September 2009. The aim was to share and discuss the information reported by the media on these investment trends and the issues raised in relation to development.

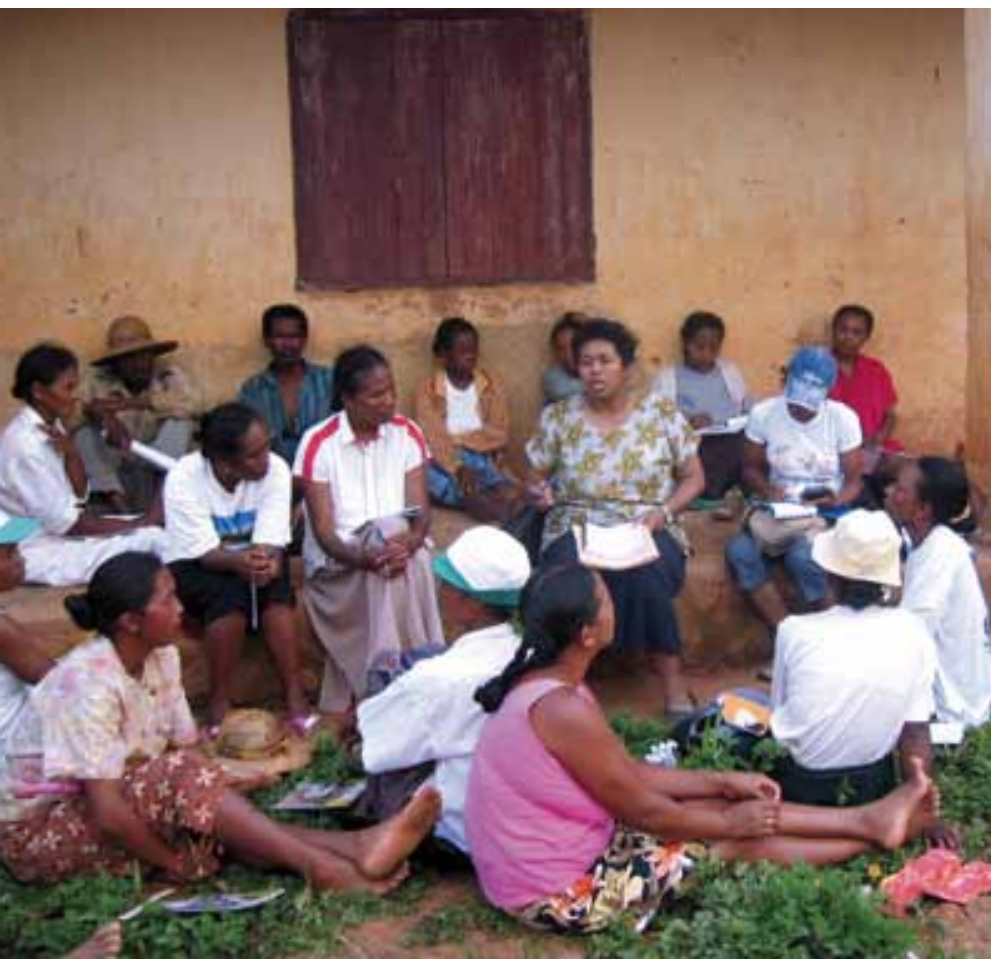

\section{Debate on}

\section{development issues}

Feeding debate, changing ideas and supporting decision-making are the main aims of Perspective, a new four-page policy brief launched recently by CIRAD and aimed at policyand decision-makers. Each issue is based on research work, and presents a novel idea or policy relating to an issue connected with sustainable development that is of strategic importance for developing countries: food security, land tenure, climate change, energy security, forest management, standards, etc. In the first issue, Alain Karsenty analysed the mechanisms for controlling deforestation ("Deforestation and climate change: what the (carbon) )market cannot do..."). In the second, Franck Galtier supplied new elements for analysing the food crisis ("The need for public intervention to stabilize food prices in developing countries").

\section{Water}

The new International Centre for Water Economics and Governance in Africa, IWEGA, was launched in May 2009 by two universities and a research centre in Africa, along with the G-Eau joint research unit, led by CIRAD. The aim is to build a centre of excellence for research and higher education in Eastern and Southern Africa in the fields of water economics and governance, particularly targeting qualification courses and on-the-job training.

\section{Sciences Po-CIRAD}

\section{seminar}

A monthly seminar is organized by CIRAD and Sciences Po in Paris, on the governance of sustainable development. While the sustainable development concept has in recent years become a vector for economic change, it also appears to be a vehicle for change in political and institutional practices. In 2009, the seminars were devoted to a study of standards and other such mechanisms, with the aim of defining and disseminating "good practices", particularly in the agricultural, forestry and agro-food fields. How can such regulatory instruments help in redefining the borders between "public" and "private"; between "technical" and "political"; in changes of scale as regards democratic control ("national", "international”, “transnational"); in redefining the North-South relations they are intended to support? 


\section{Feeding the world in 2050: an achievable goal, according to the Agrimonde foresight study}

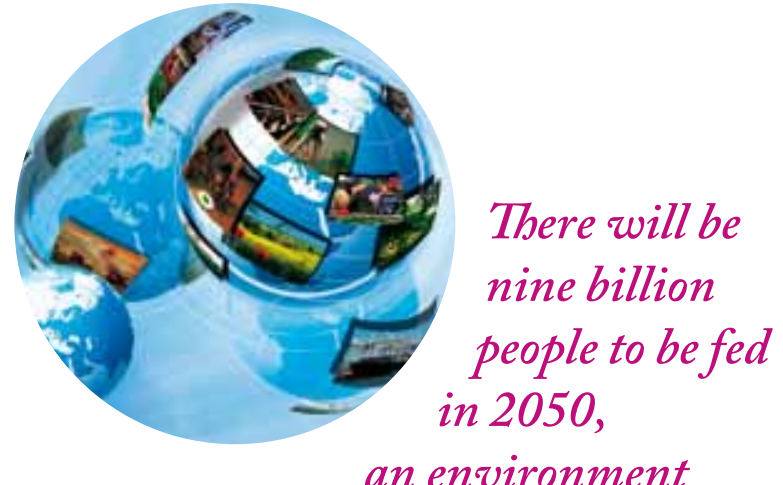

needing to be protected, and fossil fuels to be saved.

In this context, what does the future

bold for global farming and food systems? And what are

the challenges for research?

These are the questions set for

the Agrimonde foresight study undertaken by CIRAD and

INRA in 2006. The first phase

resulted in a report that

concluded that it should be

possible to feed the world in 2050, subject to various terms and conditions

that challenge our political and scientific choices.
TRA and CIRAD launched the 1 Agrimonde foresight study in 2006 in an attempt to consider the role of agriculture in various global change scenarios and to identify the issues agricultural research will have to tackle in the coming years. The exercise is intended to provide them with the means of anticipating such changes and preparing for the future in terms of public research facilities and priorities, and also of international strategic positioning. The first phase, which has just been completed, looked at two scenarios.

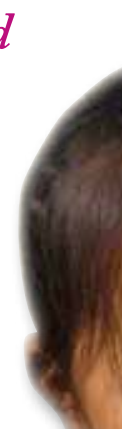

The two scenarios used the same time horizon, 2050, and the same human population growth and migration hypotheses: those of the UN median forecasts. However, they dif-

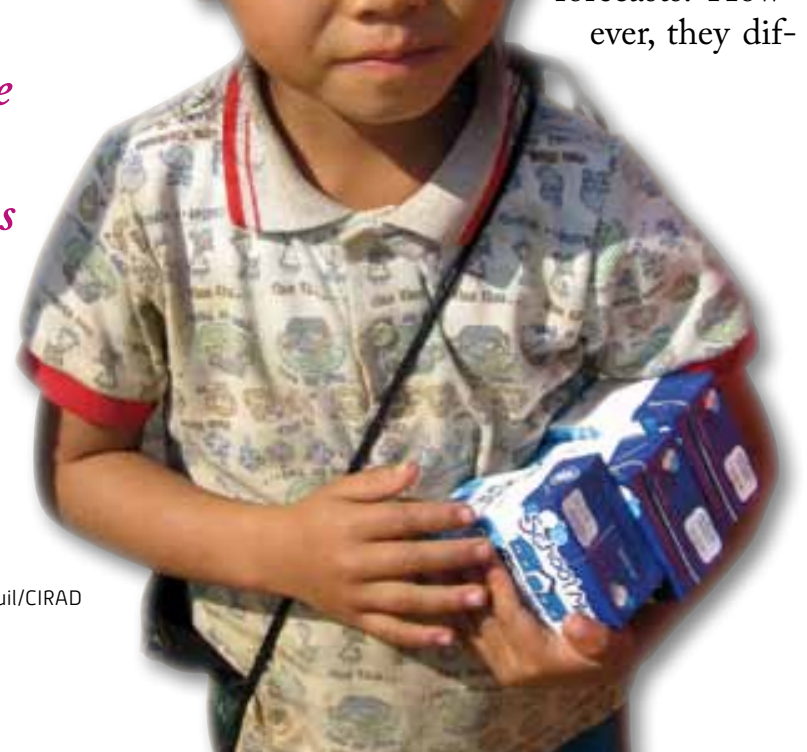

fered as to the course taken by the agricultural and food systems: the paths studied reflected two contrasting global visions.

\section{Two scenarios}

for the future

The first scenario attempted to apply the principles of sustainable development through ecological intensification of production and a reduction in current consumption inequalities: with this scenario, food calorie availability increased by $25 \%$ in regions such as subSaharan Africa, while it fell by $25 \%$ in developed, OECD-member countries. In this case, ecosystems and environmental issues were managed proactively.

With the second scenario, the analytical grid corresponded to the Millennium Ecosystem Assessment "global orchestration" scenario, in which economic growth is strong and the reduction in poverty particularly significant. This scenario was characterized by a substantial increase in calorie yields per hectare cultivated, and by unhindered global trade. It also centred on the assumption that environmental problems can always be overcome once they become too acute: in other words, they are not anticipated but managed reactively. 


\section{Feeding the world, regulating trade}

In both cases, based on the hypotheses put forward, feeding the world in 2050 would not appear to be impossible. However, three regions-sub-Saharan Africa, Asia and North Africa-Middle Eastwould have overall shortfalls and would have to resort to imports, hence the importance that needs to be given to the organization and regulation of world trade in international talks on food security.

The first scenario assumed a radical break with past trends. Calorie availability throughout the world would be $3000 \mathrm{kcal}$ per head, per day, with $2500 \mathrm{kcal}$ of plant origin and $500 \mathrm{kcal}$ of animal origin. However, today's figure does not exceed $2500 \mathrm{kcal}$ in sub-Saharan
Africa, whereas it is around 4000 $\mathrm{kcal}$ in OECD countries. In the latter region, therefore, it implies major changes in terms of wastefulness management and diet.

\section{Ecological intensification, a major challenge}

Lastly, the foresight study looked at changes in yields and in the areas used for production, along with the technical, economic, social and environmental implications of those changes. Ecological intensification, which makes maximum use of ecological processes, saves on fossil fuels and associates different production systems within a given area, appears to be of vital importance.
These analyses were discussed extensively with the various French stakeholders during the Paris International Agricultural Show and at a conference in Montpellier in October 2009, then in Rome (FAO), Washington (IFPRI), Montevideo (PROCISUR), Santiago de Chile (CEPAL), and Wageningen (CTA), with a view to sharing, debating and exploring these Agrimonde outcomes in greater detail.

Contacts $>$ Patrick Caron, Bruno Dorin, Centre international de recherche sur l'environnement et le développement (CIRED)

\section{FORFURTHERINFORMATION}

INRA, CIRAD, 2009. Agrimonde, Scenarios and Challenges for Feeding the World in 2050. Summary Report. Paris, INRA, CIRAD, 32 p.
PARTNER

Institut nationa de la recherche

agronomique (INRA)

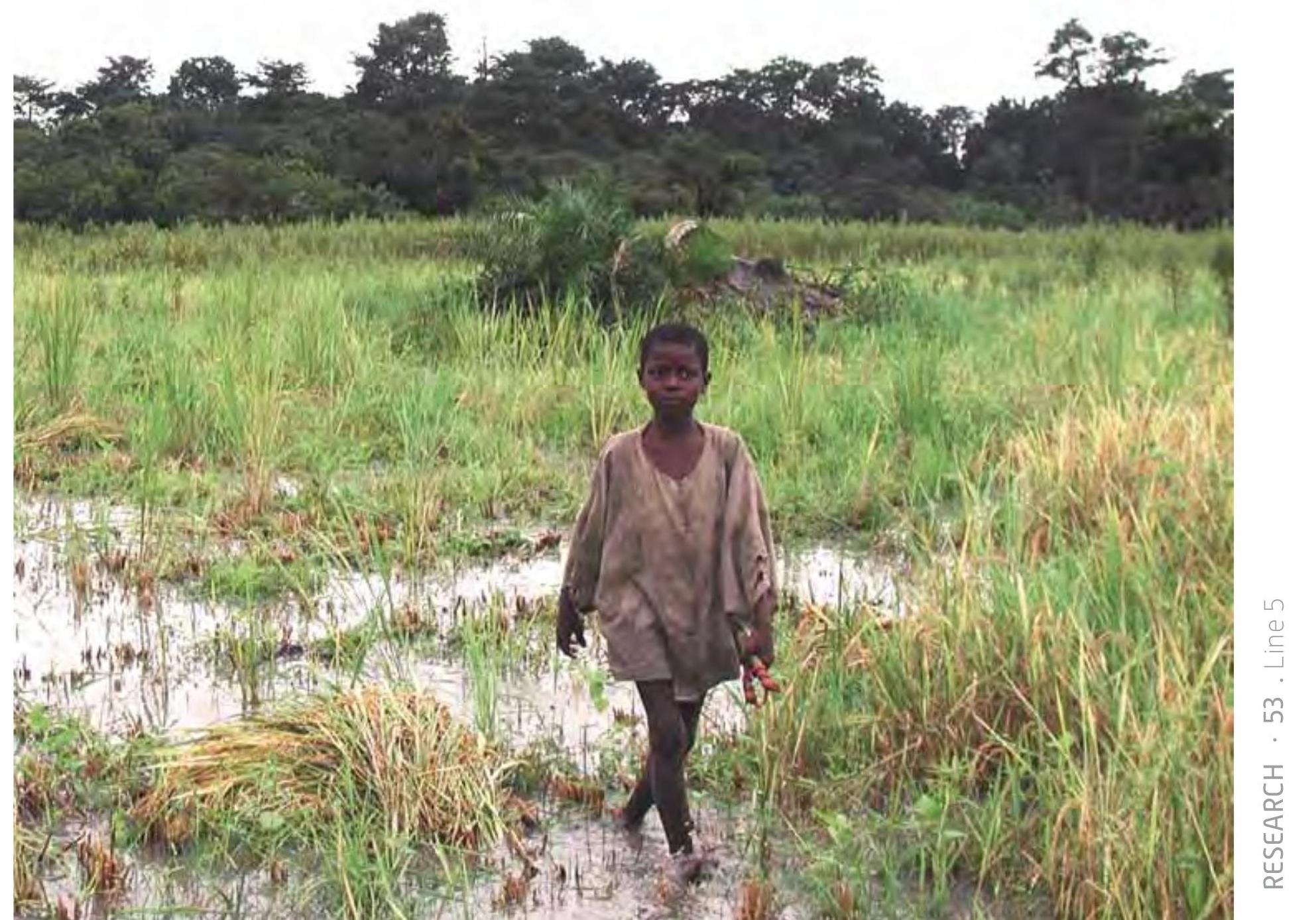




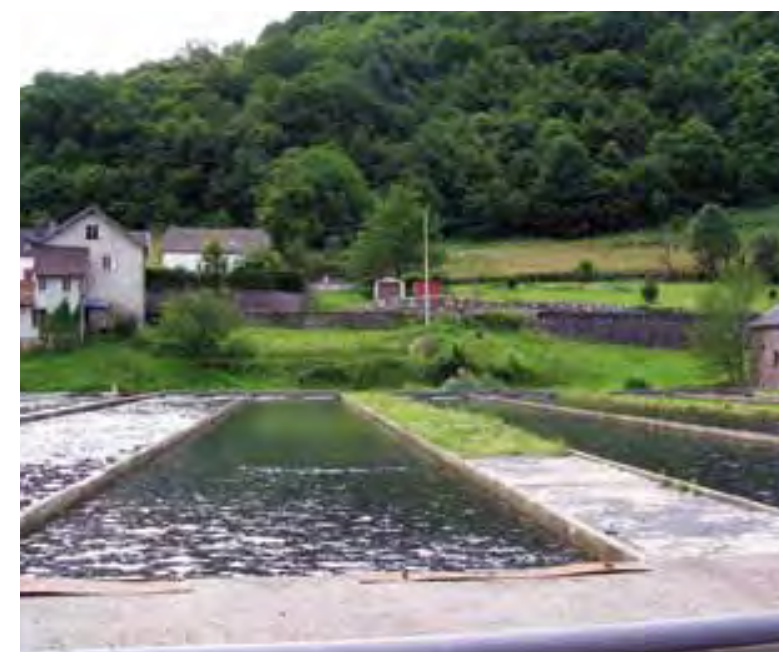

Rainbow trout farming in raceways, France $\odot$ J. Aubin/INRA

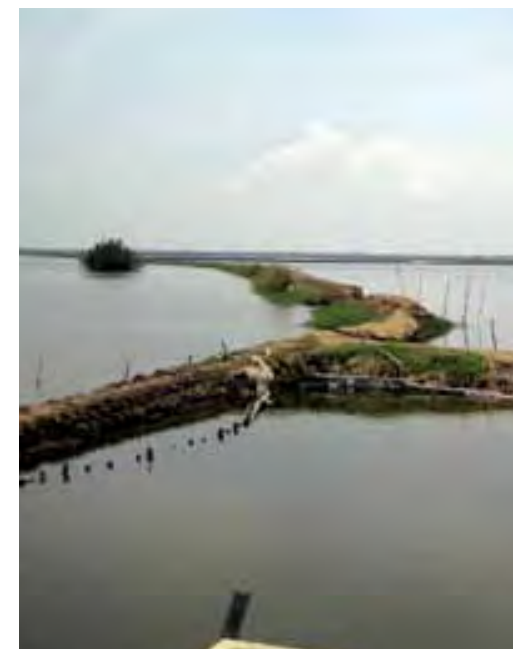

Brackish coastal fish and crustacean polyculture pond, Pampanga, Philippines (๑) J. Lazard/CIRAD

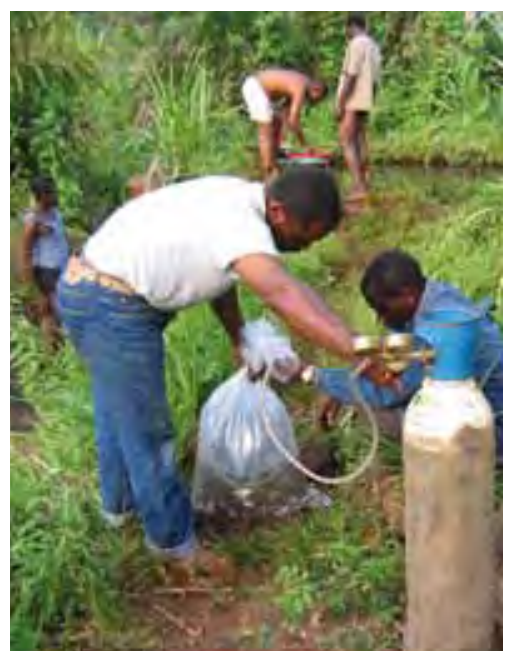

Transporting Nile tilapia hatchlings, Cameroon ๑) J. Lazard/CIRAD

\section{Assessing the sustainability of fish farming systems}

$\mathrm{T}$ here are a number of questions surrounding the sustainable development of fish farming, which is now the only way of satisfying the increased demand for products of the sea, lakes and rivers. In this sector, the available references and attempts at building indicators often pertain to approaches that lack adequate consideration of the sustainable development dimensions . Moreover, these approaches are cen- participatory components.

This situation has led to a multitude of sustainable development

In the past 30 years, fish farming has shown a mean annual growth rate of over $10 \%$. However, that growth has raised a number of questions concerning its sustainability. In this sector, there are many sustainable development references and indicators, but they are little used, if at all, as they have been imposed from above and are not truly operational. Hence the need to devise a generic approach to the development of indicators that fosters implementation and ownership by the actors of this new approach to development. This is the aim of the EVAD project.

standards, guides and indicators, most of which are seen as restrictive regulations or ineffective recommendations and therefore little used. This is why it is essential to develop a generic approach that fosters implementation and ownership of sustainable development by the actors themselves.
How can the sustainable development of fish farming be assessed?

The EVAD project set out to build a system for assessing the sustainable development of fish farming that would be geared to local conditions while being extendable, 
suitable for multisite comparisons, and at the same time usable by stakeholders and thus more likely to take root. The approach adopted combines the advantages of topdown approaches, with common points of reference supplied by a reference base, and those of bottom-up approaches, with the inherent qualities of the participatory exercises they involve.

\section{A guide to building indicators}

Six fish farming systems were studied: in Brittany, the Mediterranean, the Philippines, Cameroon and two in Indonesia. Based on their characterization, the researchers involved produced a fish farming system analytical grid capable of taking account of sustainability issues. In addition, a database of existing references and potential sustainable development indicators was also compiled.

Lastly, a guide has been produced, along with a generic list of sustainable development principles, criteria and indicators for fish farming. The guide serves as a road map offering essential points of reference but nevertheless allowing a degree of freedom in terms of itin- eraries and a broad choice of principles, criteria and indicators. The generic base, for its part, is not a ready-made list but a reference base in which the most relevant principles, criteria and indicators pertaining to the issues, location and types of fish farming should be selected.

The proposed method of construction distinguishes several stages centring on three main phases that alternate operations carried out in conjunction with stakeholders and others devised by the initiators.

\section{The diagnosis of sustainability}

The database compiled from material selected by stakeholders at the different sites includes 13 principles, 64 criteria and 129 indicators. Despite the diversity of systems, ten principles and 25 criteria were shared by four out of the six sites. The proportion of shared indicators was much lower, with just 30 indicators shared by three sites. Using this database, a diagnosis of sustainability was carried out for each of the sites, focused on farm sustainability and on the contribution of fish farming to the sustainability of the areas in which it is practised.
PARTNERS

Centre for

Information, Training and Research for Development (CIFORD,

Cameroon), Comité interprofessionnel des produits de l'aquaculture

(CIPA), Directorate General for

Aquaculture (DGA, Indonesia), Institut de recherche pour le développement (IRD), Institut français de recherche pour l'exploitation de la mer (IFREMER),

Institut national de la recherche agronomique (INRA), Institut technique de l'aviculture et de lélevage des petits animaux (ITAVI), Philippines Council for Aquatic Marine Research and Development (PCAMRD), Grand Sud Cameroun research consortium, Research Centre for Aquaculture (RCA, Indonesia), University of Montpellier I
Building a pond in a marshy depression, Cameroon (c) J. Lazard/CIRAD

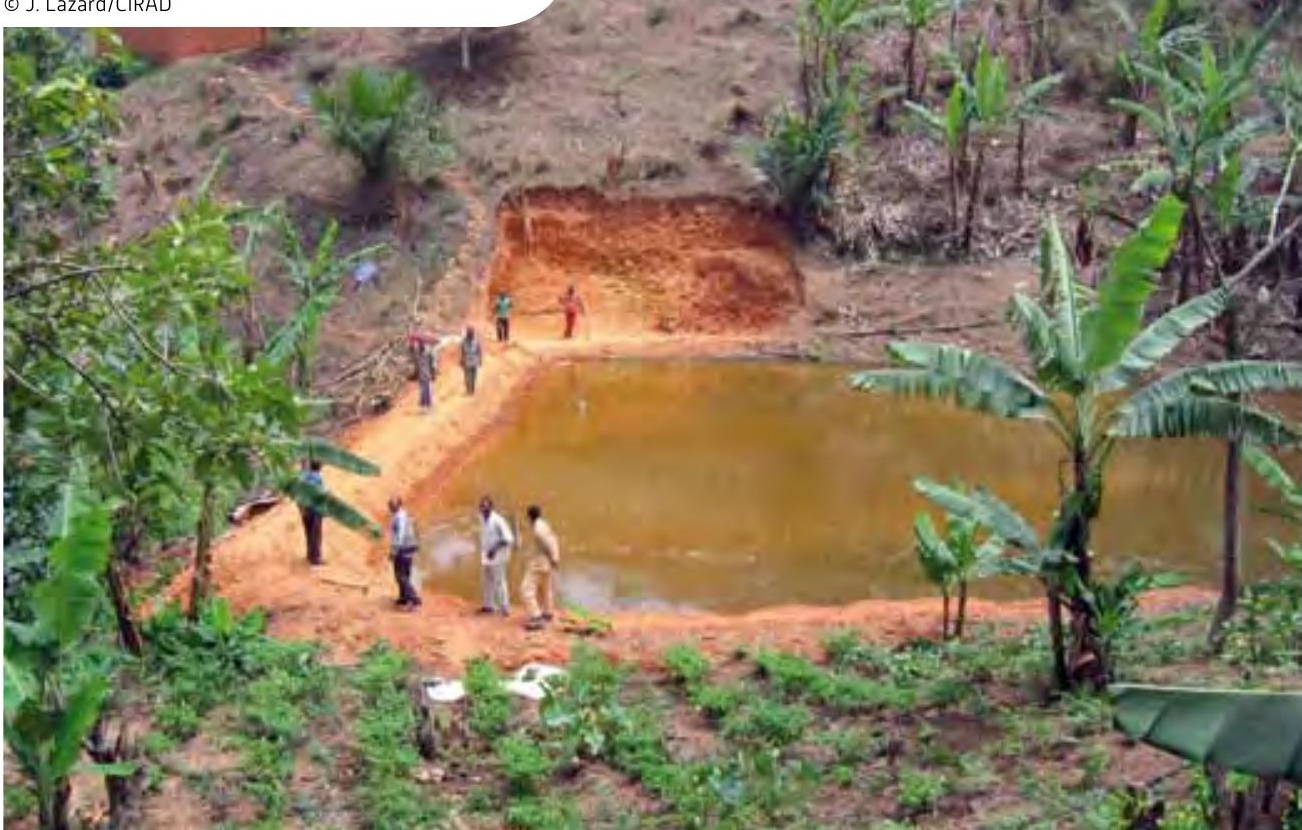

A comparison of the sustainability profiles for each site made it possible to develop a typology, based on the relative extent of their advantages and handicaps. For instance, Brittany was in a relatively good position, albeit with a different score profile depending on the different principles. The Mediterranean and the Philippines were average, with neither marked advantages nor disadvantages. Lastly, Cameroon and Indonesia, like Brittany, had more contrasting profiles depending on the principles, but were ranked lower in terms of sustainability. This varying degree of score uniformity depending on the principles needs to be taken into account when defining specific support policies for the sector, given that it is easier to intervene, whether through incentives or awareness-raising, by concentrating on a small number of factors and, in this respect, clearly differentiated profiles have a comparative advantage.

Lastly, applying the life cycle analysis method to the areas studied confirmed the classification resulting from the principle-, criteriaand indicator-based approach and served to cast doubt on a widespread paradigm in connection with sustainability: the superiority of extensive-type fish farming systems.

Contact > Jérôme Lazard, Aquaculture and Aquatic Resource Management

\section{FORFURTHERINFORMATION}

Chia E. et al., 2009. Evaluer la durabilité des systèmes et des territoires aquacoles : proposition méthodologique. Cahiers agricultures, 18: 211-219.

Lazard J. et al., 2009. Diversité des systèmes aquacoles et développement durable : entre structures d'exploitation et représentations. Cahiers agricultures, 18: 199-210.

Rey-Valette H. et al., 2008. Guide to the Co-Construction of Sustainable Development Indicators in Aquaculture. CIRAD, IFREMER, INRA, IRD, University of Montpellier I, 144 p. 


\section{Private goods \\ and public services:}

\section{the need}

\section{for compromise}

\section{Cropping systems are now assessed not only} on their capacity to produce, but also on their ability to preserve natural resources. Agroforestry systems, which associate several plant species, including trees, at the same time and in the same plot, often successfully combine these two functions. Such systems, particularly those based on perennial crops such as coffee and cocoa, are widespread in Central America. Numerous research programmes have set out to improve their agronomic performance, and a range of studies are currently under way with a view to assessing the environmental services provided by such systems.

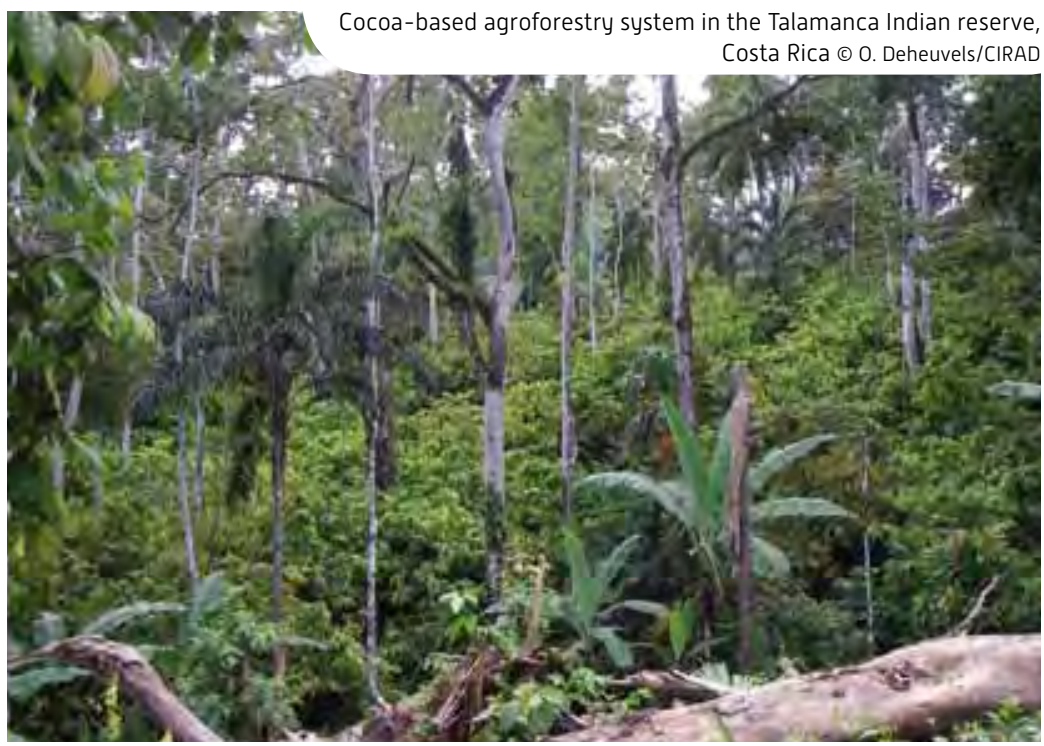

Dopulation growth in zones 1 with limited land resources is pushing more and more producers to intensify production, and agroforestry systems are becoming increasingly rare. In Central America, the main driver of agricultural development is still the added value generated by the production of private goods, in other words goods obtained from the main crop (coffee or cocoa), but also from associated plant species (wood, fruit, bark, leaves and creepers). Little is yet known about such cropping systems, and the environmental services provided have not been properly quantified. In 2008, researchers from CIRAD embarked upon studies of two of the region's most representative types of agroforestry systems: those based on coffee and those based on cocoa.

Coffee-based systems: quantifying the environmental services provided

For coffee-based agroforestry systems, in which the degree of shade
PARTNERS

CABI (United

Kingdom), Centre for Ecology and

Hydrology (CEH, United Kingdom),

Centro Agronomico Tropical de

Investigacion y Enseñanza (CATIE, Costa Rica), CoopeLlanoBonito (Costa Rica), Inaforesta, INCAE (Costa Rica), Institut national de la recherche agronomique (INRA), Instituto Costarricense de Eletricidad (ICE), Montpellier SupAgro, Natural Environment Research Council (NERC, United (Guatemala),

Proyecto Cacao Centroamérica (PCC) Kingdom), Promecafe is managed to suit the coffee trees, the aim is to integrate the provision of environmental servicesand the possible accompanying funding -into the management of the system. For instance, in a small valley in Costa Rica dominated by coffee-tree plantations, researchers are working to identify the potential for increased coffee production, the relations between coffee cropping practices and erosion and, lastly, the compromises required or the complementarity between coffee production, erosion and fertility maintenance. This research fits into a broader operation: negotiations between stakeholders, assisted by computer models. The aim is to quantify the environmental services provided by coffee growers but also to assess 
to what extent the users of such services are prepared to pay for them and what incentives are required to encourage farmers to provide them.

\section{Reaching a compromise between production and services in cocoa-based systems}

For cocoa-based agroforestry systems, whose botanical composition and structure are more complex, the aim is to compare the existing compromises between agricultural production and environmental services in a wide range of very contrasting situations. This work should serve to identify the factors behind every level of compromise observed.

In 2008-2009, a regional experimental network was set up in five Central American countries: Panama, Costa Rica, Nicaragua, Guatemala and Honduras. Some forty cocoa plantations managed by local producers were chosen so as to maximize the contrasts between them: altitude, landscape, topographical situation, vegetation structure, soil quality, and the intensiveness of upkeep and harvesting methods. Each plantation was then characterized in terms of its botanical composition and vegetation structure, and its cocoa production was assessed. At the same time, the environmental and ecological services provided were quantified: carbon capture by the plants and leaf litter; specific and functional biodiversity of animal and plant groups; soil quality conservation; and ability to provide habitats for the herpetofauna and cocoa pollinating flies.

The aim was to provide the actors involved in talks on natural resource management with elements to enable them to reach a compromise between the provision of environmental services and the production of private goods within agroforestry systems. This research is particularly significant in a region of the world with a very wide range of incentives to provide environmental services.

\section{FORFURTHERINFORMATION}

Deheuvels O. et al., 2007. Agricultural practices and biodiversity in cocoa production landscapes. In: 2nd International symposium on multi-strata agroforestry systems with perennial crops: making ecosystem services count for farmers, consumers and the environment, 17-21 September 2007, Turrialba, Costa Rica.

Rapidel B., Roupsard O., Navarro M. (ed.), 2009. Modelling agroforestry systems. Workshop proceedings, 25-29 February 2008, CATIE, Turrialba, $336 \mathrm{p}$.

Van Oijen M. et al., 2009. Plot-scale modelling of coffee agroforestry systems in Central America. In: B. Rapidel et al. (ed.), Modelling agroforestry systems. CATIE, Turrialba, Costa Rica, 25-28 February 2008.

Central America research consortium: web.catie. ac.cr/pcp/

Central America cocoa project: www.catie.ac.cr/pcc

Inaforesta: worldagroforestry.org/treesandmarkets/

inaforesta/

\section{Contact >}

Bruno Rapidel,

Tropical and

Mediterranean

Cropping System

Functioning and

Management

[SYSTEM]
Llano Bonito Valley, Tarrazú region, Costa Rica. This region produces the best coffee in Costa Rica. Climatic conditions are favourable, but slopes are steep to extremely steep. Trees are generally associated with coffee, but in very variable proportions ๑ B. Rapidel/CIRAD

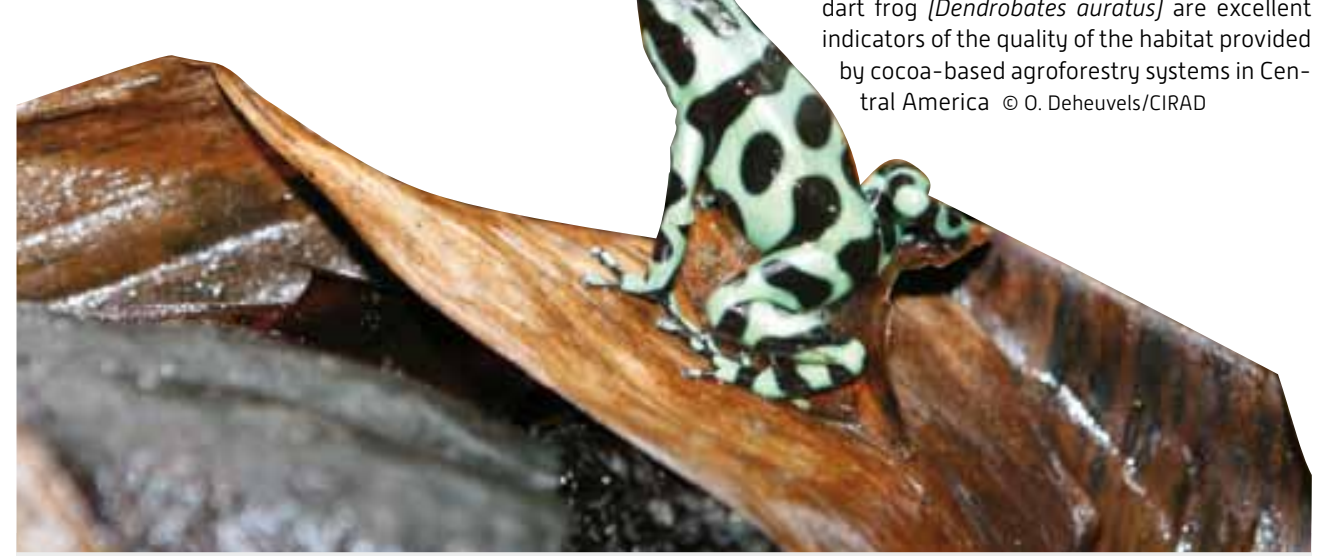

\section{Sepia, a project to model hydrological services}

The Sepia project, which was proposed recently, is intended to produce modelling tools to boost the provision of hydrological services. It should serve to fuel talks between stakeholders using indicators relevant to two watersheds: one set of talks concerns the reduction of soil erosion in a coffee plantation in Costa Rica and the other that of surface water pollution by herbicides in a vineyard in the South of France. Several models are to be developed under the project. A distributed hydrological model is to be built to estimate and incorporate, on a watershed scale, the effects of cropping practices on reducing erosion and pollution by herbicides. A bio-decisional model will be used to study the conditions that prompt farmers to change practices and provide more environmental services. The project will also be comparing the different incentives to provide hydrological services, along with their consequences. It will be applying the tools developed through experimental talks between real stakeholders, and assessing their relevance. 
Animal

production,

the treasure

of the poor

Livestock is at the very heart of greater prosperity in rural areas. However, pastoralists and mixed farmers in developing countries are among the world's most vulnerable people. They are hit head-on by drought, economic crises and conflict. Animal production, the treasure of the poor, is thus a paradoxical sector. This book shows how animal production plays a central role in farmers' lives: it provides food for their families, generates income, and is a way of accumulating capital. However, the prosperity of animal farmers cannot be reduced to the number of animals they own. Each herd is integrated into a complex technical system in which the risks are high. Its role in social relations is also crucial. Animal farmers thus have to strike a balance between several possible uses for their herd. To be effective, policies aimed at supporting animal production need to take account of this strategic and organizational complexity.

Contact > Bernard Faye, Livestock Systems and Animal Product Management

\section{land investments}

Since 2008, large-scale land acquisition projects in developing countries have been headline news. States and big businesses are behind these projects, in the hope of controlling land so as in turn to control food or energy supply chains, and their operations are generally somewhat less than transparent. Hence the current concern in countries where many smallholders do not have official ownership of the land they cultivate.

PARTNERS

World Bank, International Fund for Agricultural Development

(IFAD), International

Institute for

Environment and

Development (IIED,

United Kingdom),

International Land

Coalition (ILC),

Food and Agriculture

Organization

of the United Nations

(FAO)

To summarize the first studies conducted and launch a muchneeded debate on the issue, CIRAD organized a daylong conference in September 2009. Numerous researchers attended, along with representatives of NGOs, businesses and associations. The first results of analyses conducted by the World Bank, IIED, FAO and IFAD served to fuel the debate, along with case studies presented by CIRAD researchers on, amongst others, current trends in Madagascar, tropical forest appropriation projects, and land tenure changes in Brazil. Generally speaking, these analyses have e x p r e s s e d doubts about the real benefits of the trend for developing countries, and stressed the necessity to supervise such transactions to ensure they fit into a fully controlled agricultural development strategy.

Contact > Perrine Burnod, Spatial Information and Analysis for Territories and Ecosystems [TETIS]

\section{FORFURTHERINFORMATION}

Les investissements fonciers à grande échelle : Quelles réalités? Quelles conséquences pour l'agriculture familiale et quels choix de développement ?

http://tetis.teledetection.fr/index.php?option=com content\&task=view\&id=521\&Itemid $=1$

Teyssier A., 2009. Encadrer les cessions de terres. Spore, 142.

For Sale board in Madagascar

(๑) A. Teyssier/CIRAD

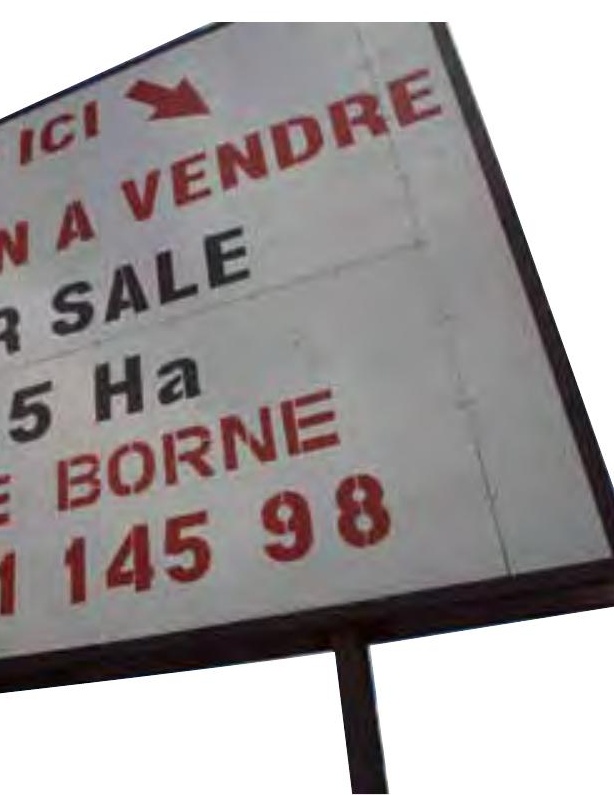




\section{Responding to climate change: building local and national capacity}

Climate change poses new challenges for many national and local stakeholders in developing countries. To implement projects aimed at mitigating or adapting to such change, it is often vital to build local capacity in terms of both designing such projects and participating in international talks. Through the training it offers, the support it provides and the dialogue it maintains with national and regional actors, CIRAD can play a crucial role in this field.

T he forestry projects under the Clean Development Mechanisms (CDM) have to conform to methodologies and to a cycle that are not easy to understand. Likewise, climate change adaptation projects may be granted funding, which candidates need to know about beforehand and for which they need to apply by demonstrating the merits of their project. CIRAD organizes training courses in Latin America and Africa in designing projects under the CDM; they are intended for staff members from nongovernmental organizations, ministries, the private sector and universities, and serve to support those

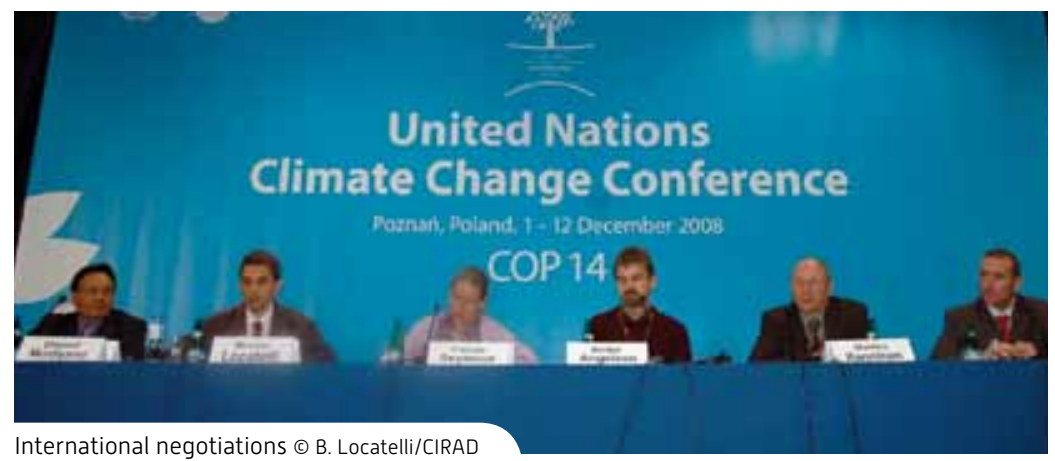
it requires knowledge of the issues for the various sectors and regions in the country concerned. The available information is often too sketchy to draw up policies and assess their efficacy. CIRAD provides technical and institutional solutions with a view to identifying the focal points and establish-
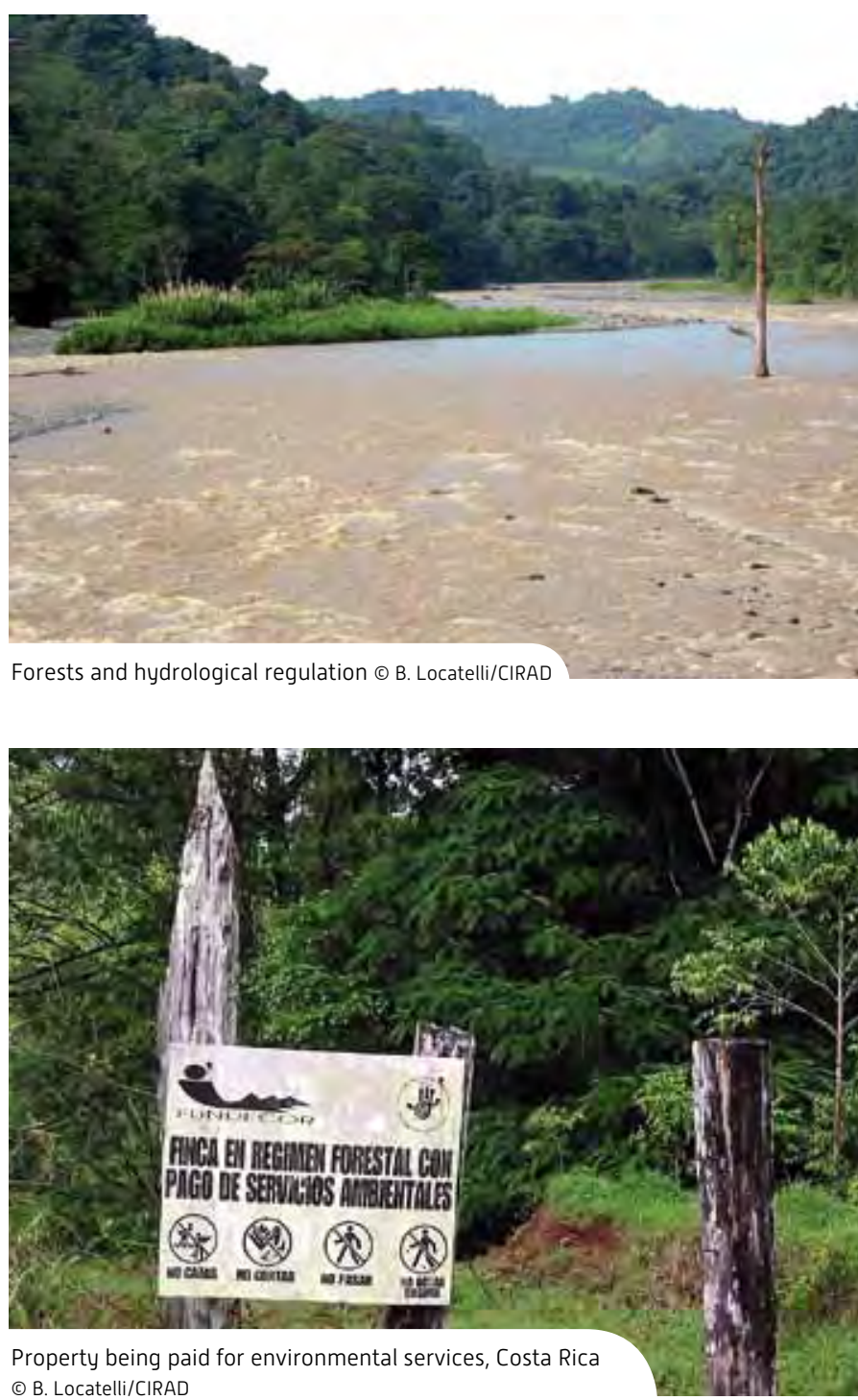

Contact > Bruno Locatelli, Tropical Goods and Forest Ecosystem Services ing national and project data sheets. It has done so in both Central America and Central Africa.

Lastly, countries need to work out national and regional positions and arguments with a view to talks at international conventions. The large number of topics under negotiation at any given time and the small number of negotiators for some developing countries pose problems. Regional initiatives and dialogue between policymakers and scientists can facilitate the process of preparing for negotiations. 


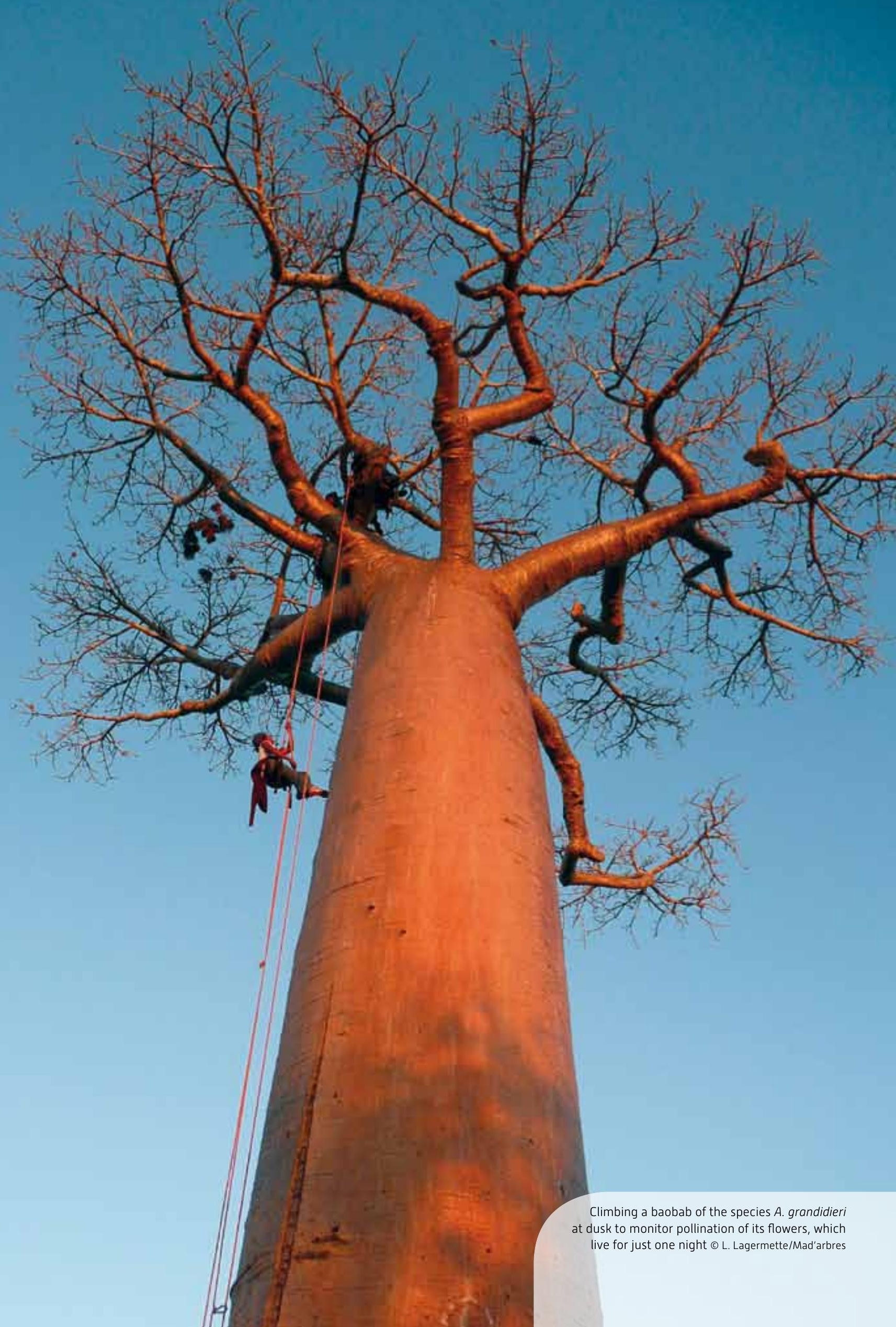



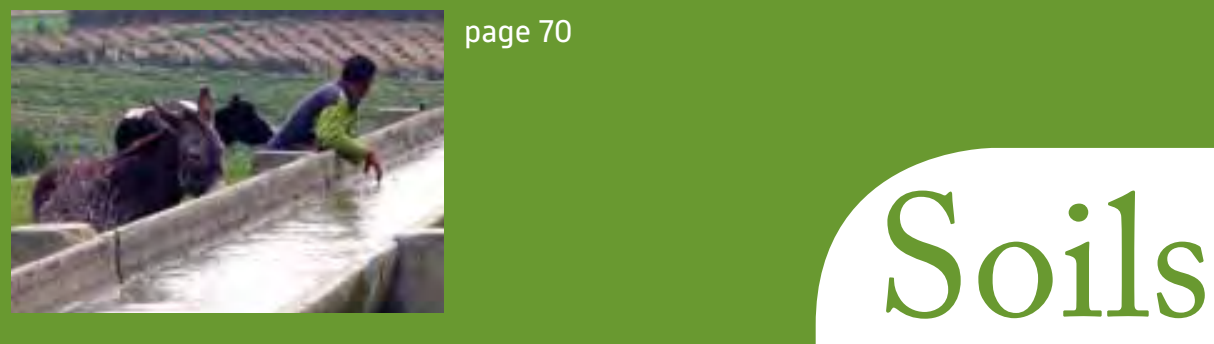

pages 62 to 64

pages 66 to 68

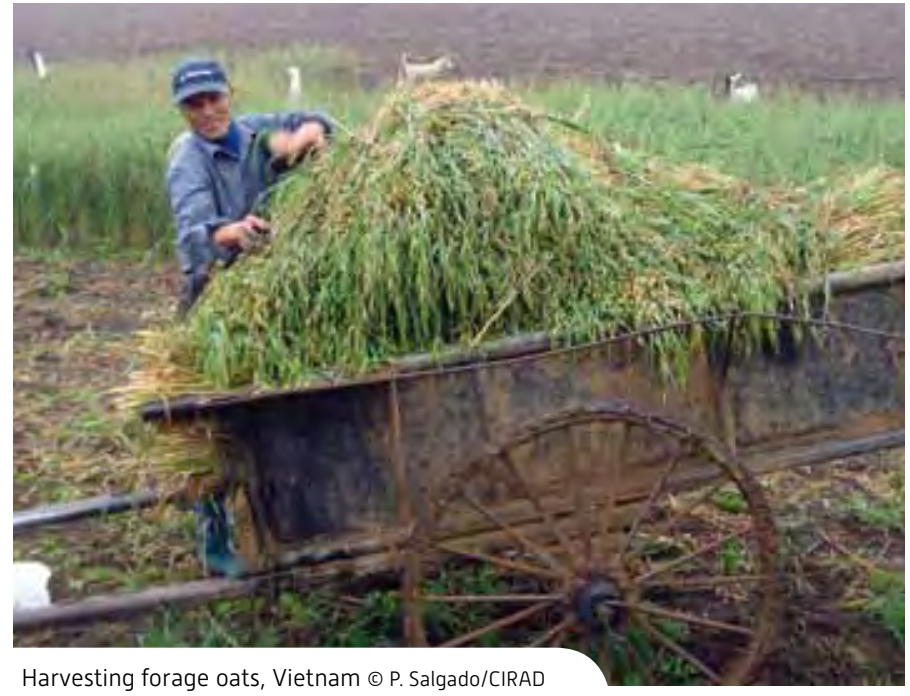

PRASAC, priority partner

The extension of agriculture puts pressure on the environment and generates conflicts of interest. Issues related to interactions between societies and the resources they manage represent a global challenge. They are a major focus of research and CIRAD partnerships. For over 10 years, the Pôle régional de recherche appliquée au développement des systèmes agricoles d'Afrique centrale (PRASAC) has been a priority partner of CIRAD in Africa. In April, at Garoua (Cameroon), it reviewed the results of 4 years devoted to a project to support regional research for the sustainable development of grasslands in Central Africa (ARDESAC) during a symposium on developing African PRASAC was mandated by CEMAC to expand its operaCongo, Gabon and Equatorial new mandate.

\section{Biodiversity}

The equitable sharing of benefits arising from biodiversity is the focus of international agreements. The "Localizing products: a sustainable approach for natural and cul- at stimulating debate on links between biological and cultural diversity and processes for making effective use of local specialty products. It was also the theme chosen by CIRAD for the first "Planète mode d'emploi" salon that took place in Paris in September. Two research projects were presented —on the Amazon Forest and on the W Regional Park in West Africa一which highlight how biodiversity conservation can be reconciled with agricultural development.

\section{Amazonia} ensure sustainability. In view of its grassland experience, tions in the six countries it covers, i.e. Cameroon, Chad, Central African Republic, Guinea, thus encompassing other agrosystems. CIRAD will provide support under this tural diversity in the South?" symposium, organized in Paris in June by UNESCO, CIRAD, IRD and MNHN, was aimed the FLOAGRI project being conducted by CIRAD and its partners. Analyses of interactions between farming and forests in pioneer settlement front areas will also continue to be a priority for researchers. Lastly, in a broader sense, CIRAD is involved in studies on how to improve the environmental services provided by forest ecosystems.

\section{Teaching in}

\section{universities abroad}

Over 40 CIRAD researchers holding posts in universities outside France are teaching courses in these fields. For instance, one CIRAD researcher at the University of Pretoria is coordinating two training modules on "Managing natural resources for rural development" as part of the Agricultural Sciences, Agroforestry and Environmental Forestry Master's programme; another is coordinating one discipline in a multidisciplinary Agroecosystem and Agroecology Master's programme at the Centre for Agricultural Science of the Federal University of Santa Catarina in Brazil; while another is teaching a course on "Modelling Human Ecosystems with Agents" as part of an Applied Anthropology for Development Master's programme at the Australian National University. 

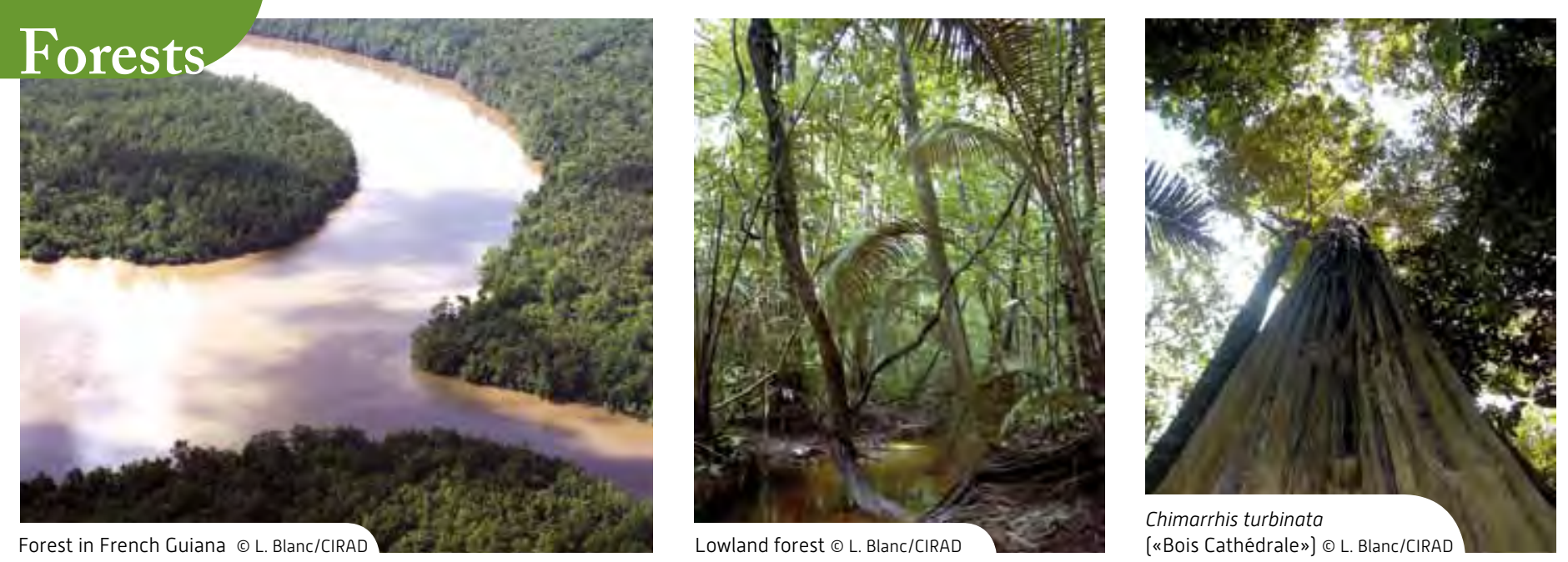

\section{Understanding the role of tropical rainforests in the carbon cycle}

Forests play a key role in the carbon cycle. It is essential to accurately evaluate their carbon storage capacity in order to understand their function, especially their potential to mitigate global warming. This is the goal set by the scientific partners of GUYAFOR, i.e. a network of plots set up for studying forest dynamics in French

\section{Guiana.}

Tor several decades, permanent, $I$ unique, tropical forest research plots have been set up in French Guiana, such as the BAFOG plots located near the town of Saint-Laurent-du-Maroni and the Paracou and Nouragues research stations. ONF, CIRAD and CNRS recently decided to integrate these research plots into the GUYAFOR network and to standardize forest dynamics monitoring, environmental assessment and data management methods.

In the last two years, research carried out via this network has been focused on natural forest carbon storage and long-term changes as a possible result of climate change. The dynamics of carbon stock recovery in logged forests are also being investigated.
Carbon accumulation in response

\section{to past disturbances}

At the Paracou research station, population data collected for 25 years in six 6.25 ha plots revealed that the natural forest stand acts as a carbon sink, with 0.17-0.80 t/ha of carbon accumulated yearly. These results confirmed the conclusions of studies carried out in the Amazon and Congo Basins. The interpretation of this carbon accumulation is still, however, controversial-is it a forest response to climate change or a reaction to past disturbances? Initial results seem to confirm the latter hypothesis. Changes in tree diameter distributions over the 25-year monitoring period are typical of regenerating forests. The 
rate of mortality of large-diameter trees has a major effect on the carbon balance, indicating that the degree of forest maturity is a key factor in this balance. Finally, in Amazonia (Amazon Basin and Guyana Shield), a recent study provided solid evidence that a climatic disturbance such as drought can trigger a decline in the forest carbon balance.

\section{5 years to replenish the carbon stock}

Another major result of these studies concerns the evolution of carbon stocks in logged forests. Although logging for timber or fuel wood generates goods and income, it also fosters carbon emissions into the atmosphere, thus exacerbating the impact of deforestation. However, a logged forest restores carbon during regeneration, with the emergence of new trees and the growth of existing trees. At Paracou, it takes 45 years for the forest to recover the carbon stock lost with a $30 \mathrm{~m}^{3} /$ ha timber extraction. This duration could be reduced by using low-impact logging techniques.

\section{Estimating forest carbon from aerial data}

Beyond these results, the GUYAFOR network participates in the development of new methods for estimating forest carbon on the basis of aerial data. It recently joined Biomass, an ambitious project that is geared towards designing a synthetic aperture radar system operating in the P-band frequency (432$438 \mathrm{MHz}, 68 \mathrm{~cm}$ wavelength), which should enable observation of spatial biomass distributions on a global scale. This project was selected as one of three can-
PARTNERS

Centre national de la recherche scientifique (CNRS, France), Office national des forêts (ONF, France), Institut national de la recherche agronomique (INRA), Université des Antilles et de la Guyane, Ecole nationale du génie rural, des eaux et des forêts (ENGREF), AgroParisTech didates for the next European Space Agency Earth Explorer Core Mission. After validating radar telemetry techniques for boreal and temperate forests, the GUYAFOR network has been selected for validating these techniques in tropical rainforests. An intensive aerial data collection campaign took place in August 2009 at the Paracou and Nouragues research stations.

\section{Contact > Lilian Blanc, Ecology of the Forests of French Guiana [UMR ECOFOG]}

\section{FORFURTHERINFORMATION}

Blanc L. et al., 2009. Dynamics of aboveground carbon stocks in a selectively logged tropical forest. Ecological Applications, 19: 1397-1404.

Phillips O.L. et al., 2009. Drought sensitivity of the Amazon rainforest. Science, 323: 1344-1347.

Rutishauser E. et al., 2009. Above-ground biomass dynamic in a rainforest of eastern South America. Journal of Vegetation Science. (in press) 
Forests
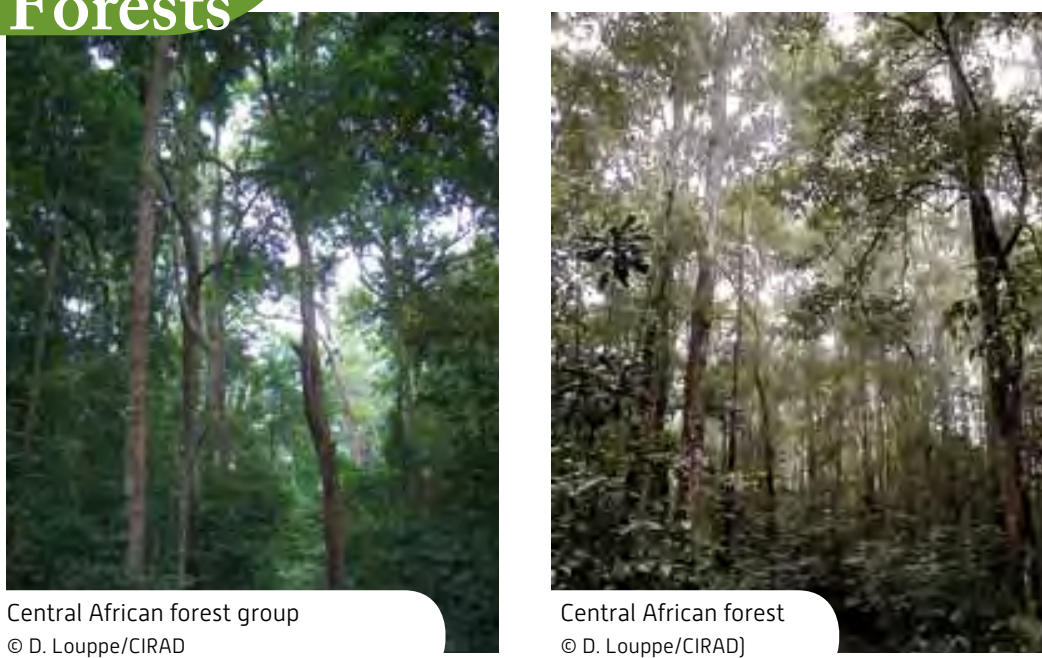

\section{Monitoring forest dynamics in Central Africa}

The reform of the forest codes that Central African countries launched 10 years ago has led to the implementation of forest management plans. Logging techniques are now well mastered, but knowledge on the ecology of the logged tree species is still incomplete. It is essential to set up permanent sample plots for monitoring forest dynamics based on wellestablished principles so as to be able to collect information on the structure and dynamics of species and stands before and after logging.

CIRAD, based on its experience gained for over 25 years in Africa, Asia and South America, was mandated by the Central African Forest Commission (COMIFAC) to develop a scientific and technical reference base to which any stakeholder wishing to set up a permanent sample plot in a natural tropical forest can refer. A manual was published that outlines all of these recommendations. A first 400 ha permanent sample plot was set up according to these principles in the Yoko Forest Reserve near Kisangani in the Democratic Republic of the Congo, as part of a project to revitalize agricultural and forestry research.

Contact > Nicolas Picard, Tropical Forest Goods and Ecosystem Services: Facing Global Change [UPR BSEF]

\section{PARTNERS}

Commission des forêts d'Afrique centrale (COMIFAC), University of Kisangani (Democratic Republic of the Congo)

\section{FORFURTHERINFORMATION}

Chagneau P., Mortier F., Picard N., 2009. Designing permanent sample plots by using a spatially hierarchical matrix population model. Journal of the Royal Statistical Society, Series C (Applied Statistics), 58: 345-367.

Picard N., Gourlet-Fleury S., 2008. Manuel de référence pour l'installation de dispositifs permanents en forêt de production dans le bassin du Congo. Yaoundé, Comifac, $265 \mathrm{p}$.

Picard N. et al., 2010. Permanent sample plots for natural tropical forests: a rationale with special emphasis on Central Africa. Environmental Monitoring and Assessment, 164 (1-4): 279-295.

\section{Forests of the Congo Basin}

The report The forests of the Congo Basin: State of the Forest 2008 presents an update on the status of dense tropical humid forests in Central Africa. It covers the six countries in which this type of forest prevails, including Gabon, the Democratic Republic of the Congo, Equatorial Guinea, Cameroon and the Central African Republic. It pools the knowledge of over 80 authors. It provides a new deforestation reference measurement for the Congo Basin. It is divided into three main parts: national and regional syntheses; environmental services provided by the forests; and information on landscapes, as defined by the Congo Basin Forest Partnership (CBFP). This report, which is published every 2 years, supplements the regularly updated online knowledge base (www.observatoirecomifac.net). It has been placed under the interministerial trusteeship of the Central African Forest Commission (COMIFAC) and was distributed during a plenary CBFP meeting that was held in Yaoundé (Cameroon) on 11 and 12 November 2009. The report is available online free of charge in English and French. It is a product of the Observatory for the Forests of Central Africa (OFAC). This observatory was launched by the European Kinshasa-based FORAF project, which is operated by a consortium managed by CIRAD.

Contacts $>$ Carlos de Wasseige, Alain Billand,

Tropical Forest Goods and Ecosystem Services: Facing Global Change [UPR BSEF]

\section{PARTNERS}

Center for International Forestry Research (CIFOR), Forêts Ressources

Management (FRM, France), Joint Research Center (JRC, European Union), Université catholique de Louvain (Belgium)

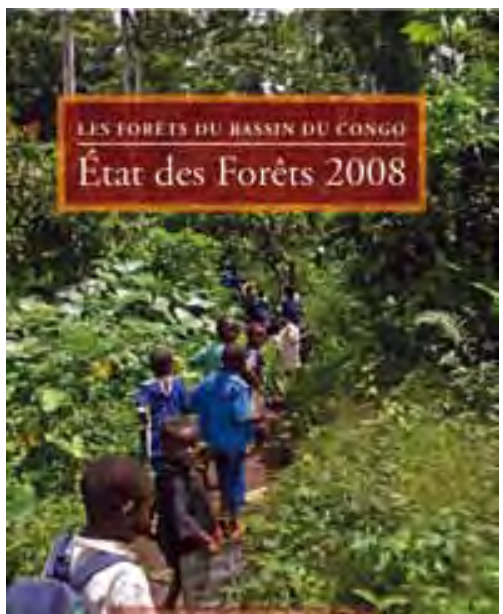

FORFURTHER INFORMATION

De Wasseige C. et al., 2009. Les forêts du bassin du Congo: état des forêts 2008 Publications Office of the European Union, $425 \mathrm{p}$.

http://www.observatoire-comifac.net/ edf2008.php 


\section{Sustainable management of baobabs in Madagascar}

Baobabs, the emblematic trees of Madagascar, have become threatened in recent decades. The ecosystems in which they grow are being transformed under the combined effects of human activities and climate change, and the question arises as to their regeneration. CIRAD and partners are involved in a comprehensive research programme aimed at laying the foundations for the sustainable management of these ecosystems.

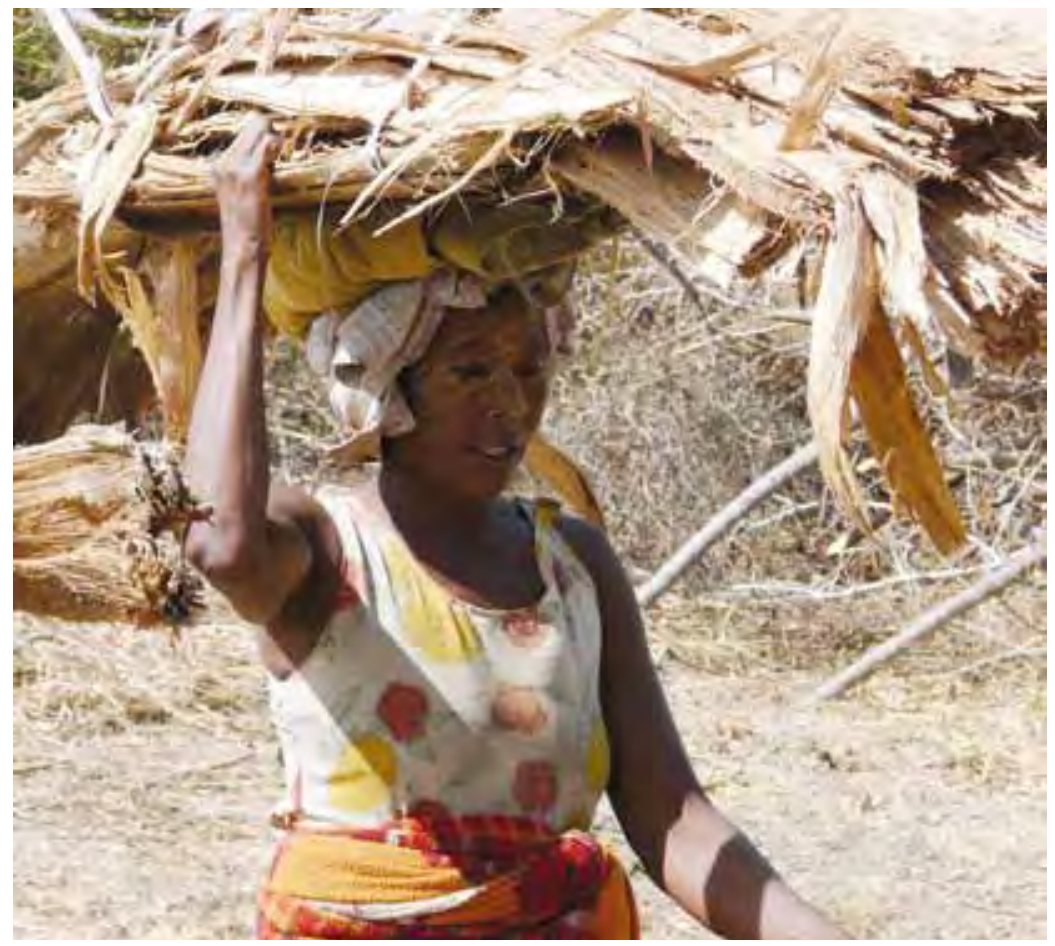

$\mathrm{M}$ adagascar is home to seven of the eight known baobab species, six of which are endemic. These multifunctional trees provide people with products and services, while also having social, cultural and landscape value. They seem to be affected by the evolution of their ecosystems which also threatens their regeneration.

CIRAD, in collaboration with its Malagasy and European partners, manages a multidisciplinary research programme that addresses three main questions: how is the diversity of the Adansonia genus structured and what is its spatial distribution? How do the species
Gathering baobab fibres for building huts in Morombe region

(c) C. Cornu/CIRAD

PARTNERS

Centre national de la recherche appliquée au développement rural (FOFIFA Madagascar), University of Antananarivo (Madagascar)

FORFURTHER INFORMATION

Corduant S., Cornu C., Danthu P., 2010. Baobabs entre ciel et terre. Montpellier, CIRAD, film, $33 \mathrm{~min}$

Leong Pock Tsy J.M. et al., 2009. Chloroplast DNA phylogeography reveals the centre of origin of the African baobab, Adansonia digitata $\mathrm{L}$. (Bombacoideae, Malvaceae). Molecular Ecology, 18: 1707-1715

Marie C.N. et al., 2009. Taking into account local practices and indigenous knowledge in an emergency conservation context in Madagascar: obvious facts and contradictions. Biological Conservation, 18 2759-2777. a means of adapting to rapid changes in their environment. This discovery raises many questions about the biological mechanisms involved and the adaptive impacts of these genetic exchanges.

The spatial distribution of baobab stands is being studied through photo-interpretation of very high spatial resolution satellite images. The initial field-validated results are promising. Over a million Adansonia grandidieri trees have been located. This method will be tailored for mapping stands of the six other species present in Madagascar.

On a local scale, a study of the famous Morondava Avenue of Baobabs highlighted the need to understand interactions between human communities and baobabs, so as to be able to propose sustainable management and conservation methods. The government has prohibited rice cropping in order to preserve the site and promote it for ecotourism, but no suitable compensation has been offered to farmers. This study revealed that the baobab has been integrated into an elaborate agroforestry system and thus protected by local people.

Contacts $>$ Pascal Danthu, Tropical Forest Goods and Ecosystem Services: Facing Global Change [UPR BSEF], Cyrille Cornu, Spatial Information and Analysis for Territories and Ecosystems [UMR TETIS] 
Imogolites: natural

nanoparticles that sequester

\section{nickel}

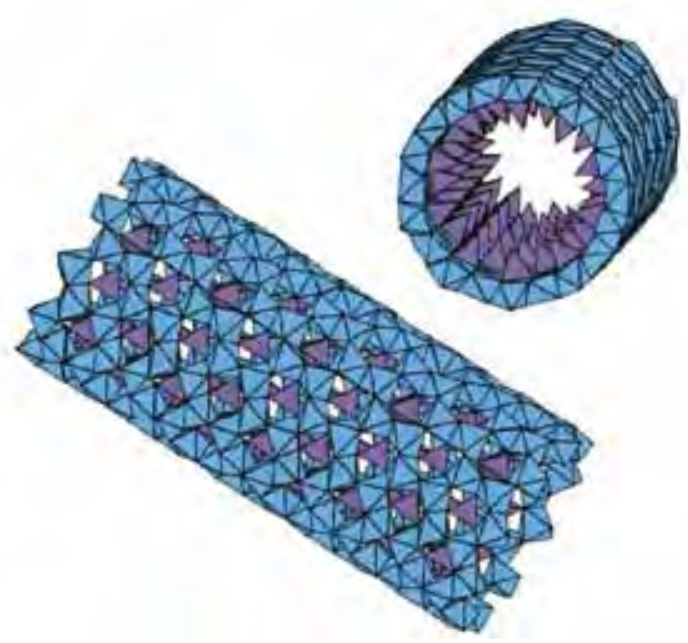

Aluminium octahedron Silica tetrahedron

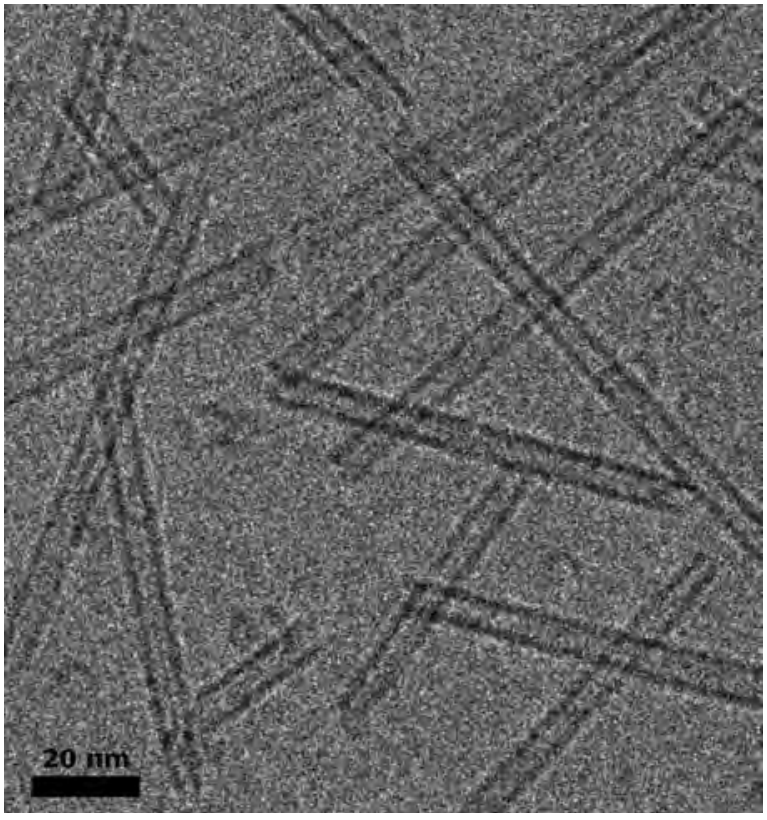

Structure and transmission electron microscopy image of imogolites (c) A. Thill/CEA-CNRS, E. Larquet/CNRS, C. Levard/CNRS

Agricultural waste recycling can be profitable, but may also lead to trace metal contamination of the environment. The volcanic soils in Réunion naturally contain high levels of such elements and waste applications in fields are therefore not authorized under the current regulations. However, these soils also contain imogolites, which are natural nanoparticles. A CIRAD team has just demonstrated that these particles can trap a substantial quantity of the nickel present in these soils, thus making it harmless.

\begin{abstract}
A gricultural waste recycling $A_{\text {can be very profitable both }}$ economically and and from the agronomic standpoint. The environmental impact of this recycling is, however, problematic because of potential contamination. Among the pollutants, trace metals such as cadmium, mercury and nickel are especially toxic to animals and plants.
\end{abstract}

In France, for instance, the spreading of sewage sludge in crop fields is tightly regulated and prohibited when the sludge has an excessively high trace metal content or when the field soils naturally contain large amounts of such metals. In Réunion, soils overlying volcanic materials often have nickel, chrome and copper contents that are above the regulatory levels. Sludge spreading is thus not allowed without a waiver.

\section{Fate of trace metals} in soils

Studies have been carried out on trace metal contents in waste, plants and soil. However, it is also essential to monitor the dynamics of these elements following applications in order to avoid contamination of water resources or the food chain and to determine how the chemical form of these elements changes. CIRAD has been conducting a series of field and laboratory studies, in collaboration 


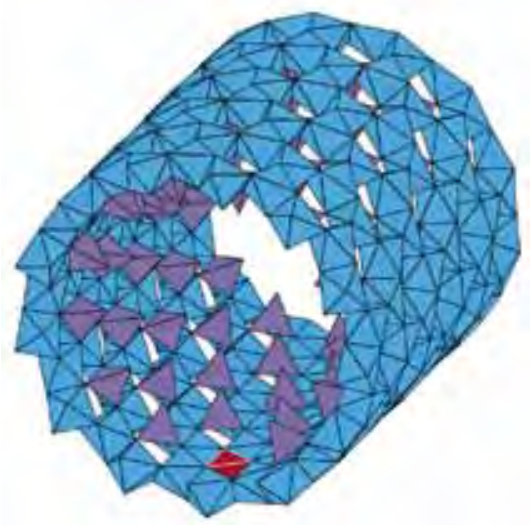

with its partners in Réunion, to address these different aspects of the problem.

In Réunion, the alteration of some volcanic materials leads to the formation of andosols, which usually have naturally high trace metal concentrations. These soils also contain imogolites, which are unique mineral particles made of aluminium and silicon that form tubes several hundreds of nanome-

Perhydrated andosol at Sainte-Rose, on the east coast of Réunion ( ) E. Doelsch/CIRAD

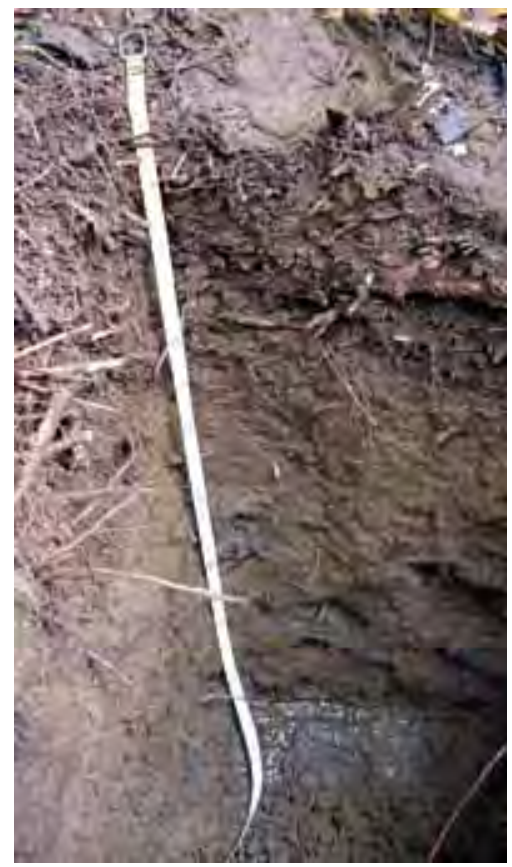

Aluminium octahedron

Silica tetrahedron

Nickel octahedron

Nickel location within imogolite gaps (c) C. Levard/CNRS

\section{FORFURTHERINFORMATION}

Levard C. et al., 2009. Role of natural nanoparticles on the behaviour of $\mathrm{Ni}$ in andosoils of la Réunion. Geochimica et Cosmochimica Acta, 73: 4750-4760. Levard C. et al., 2009. Synthesis of imogolite fibers from decimolar concentration at low temperature and ambient pressure: a promising route for inexpensive nanotubes. Journal of American Chemical Society, 131: 17080-17081.
PARTNERS

Agence de

l'environnement et de la maitrise

de l'énergie

(ADEME, France),

Centre européen

de recherche

et d'enseignement

des géosciences de

l'environnement

(CEREGE, France),

Centre national

de la recherche

scientifique (CNRS,

France), Chambre

d'agriculture de

la Réunion (France),

Commissariat à

lénergie atomique

(CEA, France),

Direction régionale

de l'environnement

de la Réunion

(DIREN, France),

European

Synchrotron

Radiation Facility

(France), European

Union, Institut

de recherche pour

le développement

(IRD), Paul Cézanne

University (France),

Région Réunion

(France), University

of Réunion (France) tres long and 2.2 nanometres in diameter. They can thus be considered as natural nanoparticles. A CIRAD team conducted synthesis studies in the laboratory and tested samples collected in the field in order to gain insight into potential interactions between imogolites and trace metals.

\section{$82 \%$ of soil-borne nickel sequestered by imogolites}

Nickel was found to be chemically bound to imogolites in experiments on imogolite synthesis and immersion in nickel-rich solutions or in natural Réunion andosol samples. Nickel, which is surrounded by six aluminium atoms, was found to be sequestered in the imogolite structure. Quantitatively, $82 \%$ of the soilborne nickel was thus trapped by these natural nanoparticles, while $10 \%$ of the nickel was still present as primary minerals, i.e. not yet altered, and less than $1 \%$ was in a so-called exchangeable form. This latter corresponds to the chemical form of nickel, which is potentially the most mobile or bioavailable and toxic to plants and animals.
These results help to explain the very low mobility and bioavailability of nickel noted in the field. They also offer new prospects for sewage sludge recovery in Réunion, especially now that fertilizer prices are rising.

Contact > Emmanuel Doelsch, Environmental Risks of Recycling [UPR]

Andic cambisol at Colimaçons, on the west coast of Réunion (c) E. Doelsch/CIRAD

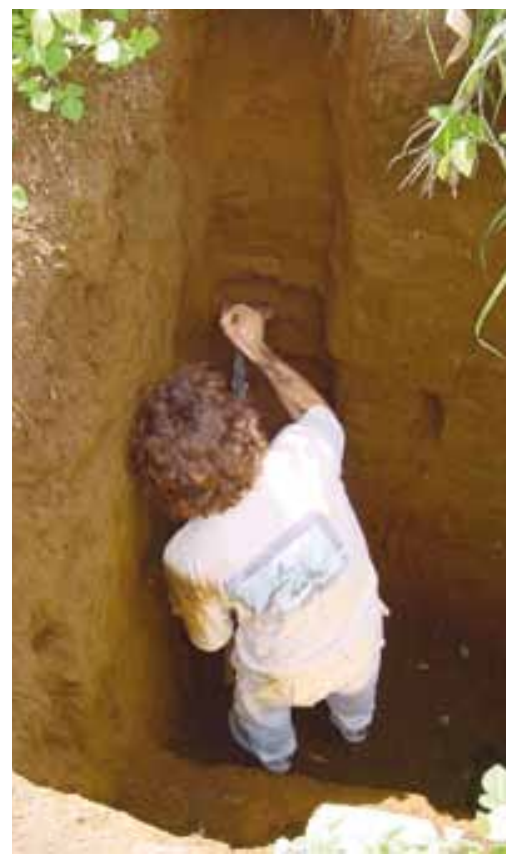




\section{Controlling nitrate pollution risks in Réunion}

In Réunion, agro-industrial and urban organic waste production will accelerate in coming years as urbanization limits farmland expansion. In this setting, how can organic waste recycling be increased and optimized while avoiding nitrate pollution of soils and groundwater?

$\mathrm{I}^{\mathrm{n}}$ n Réunion, volcanic soils, andosols, podzols and nitisols have atypical physical and biogeochemical properties, including high levels of organic matter, original organomineral complexes, a high anion retention capacity, etc. In these tropical soils, organic matter transformation and interactions between anion retention and leaching, especially nitrates, are still poorly understood. They are nevertheless key factors in determining the agro-industrial and urban organic waste recycling potential. A CIRAD team thus carried out a series of studies on the fate of nitrates in these soils.

At the Colimaçons research station, one plot was equipped to monitor water and nitrate flows to a depth of $2 \mathrm{~m}$. After slurry application, nitrate flows were substantially slowed down as compared to water flows, due in particular to the high anion retention capacity of this andosol. These soils can take up substantial quantities of nitrates, which may in turn be managed over several crop cycles in order to reduce leaching risks and optimize organic or mineral fertilizer applications.

With the aim of applying these results to a broad range of agricul-

\section{Soil map \\ An Andic Podzol \\ Andic Umbrisols/Andic Cambisols Andosols \\ a Cambisol.Umbrisol (steep slope) \\ E Cambisol.Umbrisol [sloping ledge] \\ E Leptosal \\ - 16 Haplic Phaoezems [phase III] \\ Haplic Phaoezems [ohase IV] \\ a Leptic Phaoezems [phase III] \\ a Leptic Phacezems (phase IV) \\ Mollic Fluvisats \\ No solls \\ Coastal sands \\ a Hydromarphic soils}

\section{Vulnerability map}

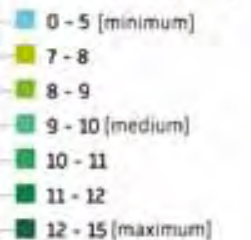

tural soil-climate conditions in western Réunion, the researchers identified and analysed existing soil maps and data which, however, proved to be of little use. This prompted them to conduct a new soil survey in this $428 \mathrm{~km}^{2}$ region, which accounts for nearly a fifth of the surface area of the island. This survey was focused especially on soil properties that affect nitrate transfer, including the nitrate retention capacity of different types of soil, hydrodynamic measurements, etc.

A thematic map of aquifer vulnerability to pollutants transferred via the soil was drawn up on the basis of all these data. Some areas were found to be much more sensitive than others to risks of nitrate transfer. Priority should therefore be focused on improving farming practices in order to enhance the nitrate retention capacity of the soil through several crop rotations.

\section{FORFURTHERINFORMATION} la Réunion (DIREN, France), European Union, Ministry of Overseas France, University of Réunion (France), Région Réunion (France)

Contact > Frédéric Feder, Environmental Risks of Recycling

Feder F., Bourgeon G., 2009. Mise à jour de la carte des sols de l'île de la Réunion : démarche suivie et problèmes rencontrés. Etude et gestion des sols, 16: 85-99.

Feder F., Robin J.G., Bourgeon G., 2008. Cartographie de la vulnérabilité des aquifères de l'ouest de l'île de la Réunion au transfert de polluants / Cartography of groundwater vulnerability to pollutants transfer in Western part of La Reunion Island. In: IWRA, 13th World Water Congress, Montpellier, 1-4 September 2008.

Payet N. et al., 2009. Modelling the fate of nitrogen following pig slurry application on a tropical cropped acid soil on the island of Reunion (France). Agriculture, Ecosystems and Environment, 134: 218-233.

The new soil map for western Réunion (top) was used to draw up a map of nitrate transfer risk (below]
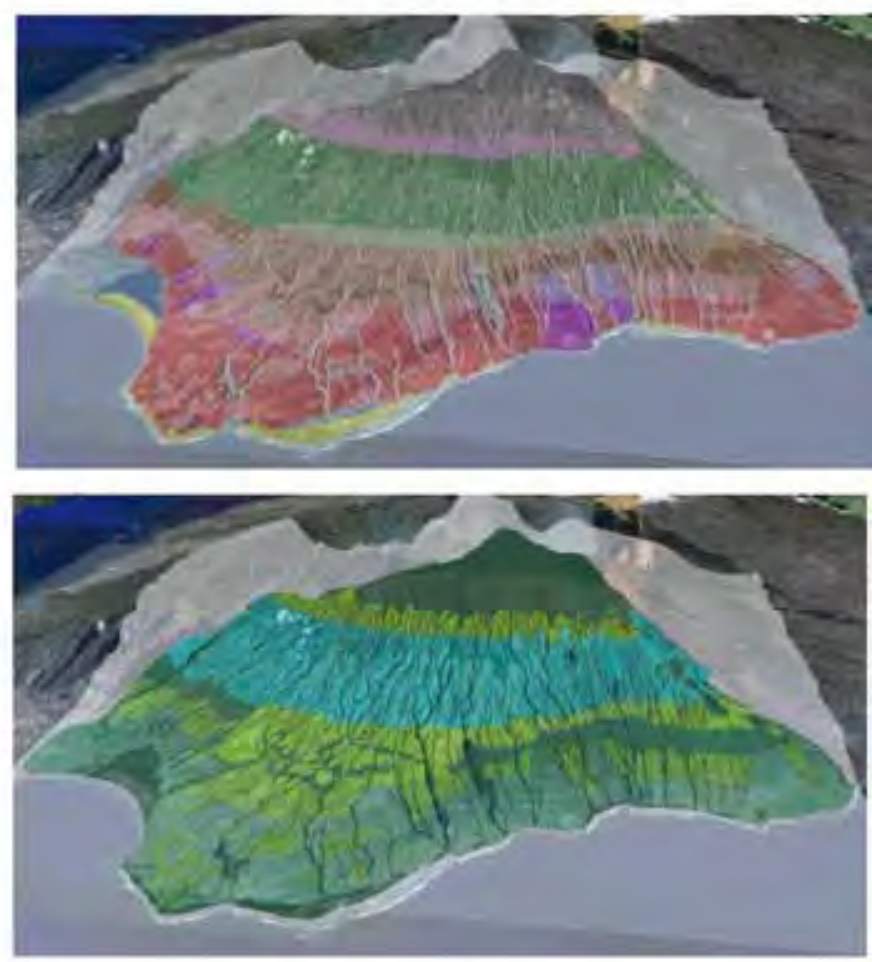


\section{Locust outbreaks}

in Madagascar: predicting risks to enhance

\section{their management}

In Madagascar, the migratory locust is a major crop pest. The last outbreak, in 1997-2000, could only be controlled via highly toxic pesticide treatments over an area of over 4 million ha. However, the causes of these outbreaks are known and prevention strategies exist. CIRAD has developed a tool to assess this risk, which combines a geographical information system, meteorological data and information on locust populations.

$\mathrm{R}$ ainfall is a key factor in migratory locust outbreaks. In Madagascar, the risk becomes high when an area gets $50-150 \mathrm{~mm}$ of rain monthly during three consecutive months. Upsurges are then possible as the locusts switch from their harmless solitary phase to the dangerous gregarious phase.

CIRAD has developed a decision support tool to help manage this outbreak risk. It consists of a geographical information system, which enables operators to locate, in real time, areas with a high outbreak potential within the original outbreak area (southern tip of Madagascar). The outbreak risk level is determined by combining three types of information: the spatial distribution of suitable biotopes, rainfall and locust densities.

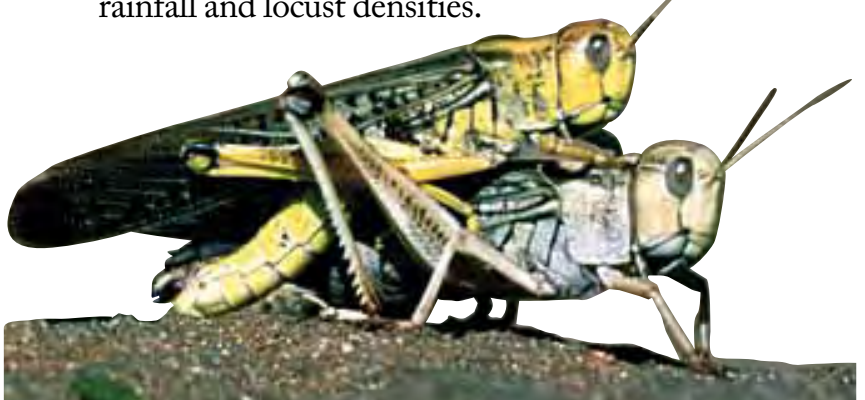

PARTNERS

African Development Bank, Centre national antiacridien (CNA,

Madagascar), Centre national de la recherche appliquée au développement rural (FOFIFA,

Madagascar),

Institut géographique national

(Madagascar),

Remote Sensing

Center (Montpellier,

France), University

of Tuléar

(Madagascar)

Migratory locusts mating in gregarious phase (c) J.F. Duranton/CIRAD
First, migratory locust biotopes were mapped on the basis of Landsat satellite images, over an area of around $185000 \mathrm{~km}^{2}$, which corresponds to the outbreak area. Around 40 biotopes were thus identified according to the plant cover and hygrotrophic conditions, and their ecological potential was evaluated.

Rainfall data are obtained through a network of 135 rain gauges, and information on locusts is collected by scouts from the national locust control centre (CNA) at hundreds of stations. This information is transmitted every 10 days to the locust monitoring section located in the gregarious area at Betioky-Sud. They are fed into a geo-referenced relational database. By combining these three types of information, an assessment of the locust situation is obtained, and the degree of reliability is evaluated by geostatistical interpolation methods.
Locust outbreak risk maps can thus be produced on a monthly basis, associated with a risk uncertainty estimate, and the outbreak risk evaluation can be further refined by combining this information with that obtained in previous months.

The first maps were published in late 2009, after users had been trained in how to operate this tool, and a user manual was drawn up. This system should enable the national locust control centre to set up more efficient preventive control procedures to reduce the migratory locust outbreak risk.

Contact > Michel Lecoq,

Locust Ecology and Control [UPR]

\section{FORFURTHERINFORMATION}

Duranton J.F. et al., 2009. Manuel de lutte préventive antiacridienne à Madagascar à l'usage des prospecteurs. Montpellier, CIRAD, 307 p. 


\section{Saving water in}

North African irrigated farming systems

Water is becoming scarce in North Africa. Rainfall has dropped by 20-30\% in different localities over the last 30 years. Irrigated farming is widespread, especially using gravitational systems that consume substantial quantities of water. These practices will inevitably bave to change. But how can water be saved? Under what conditions can this change take place on family smallholdings? CIRAD and its partners have been addressing these questions in studies carried out in collaboration with local stakeholders.

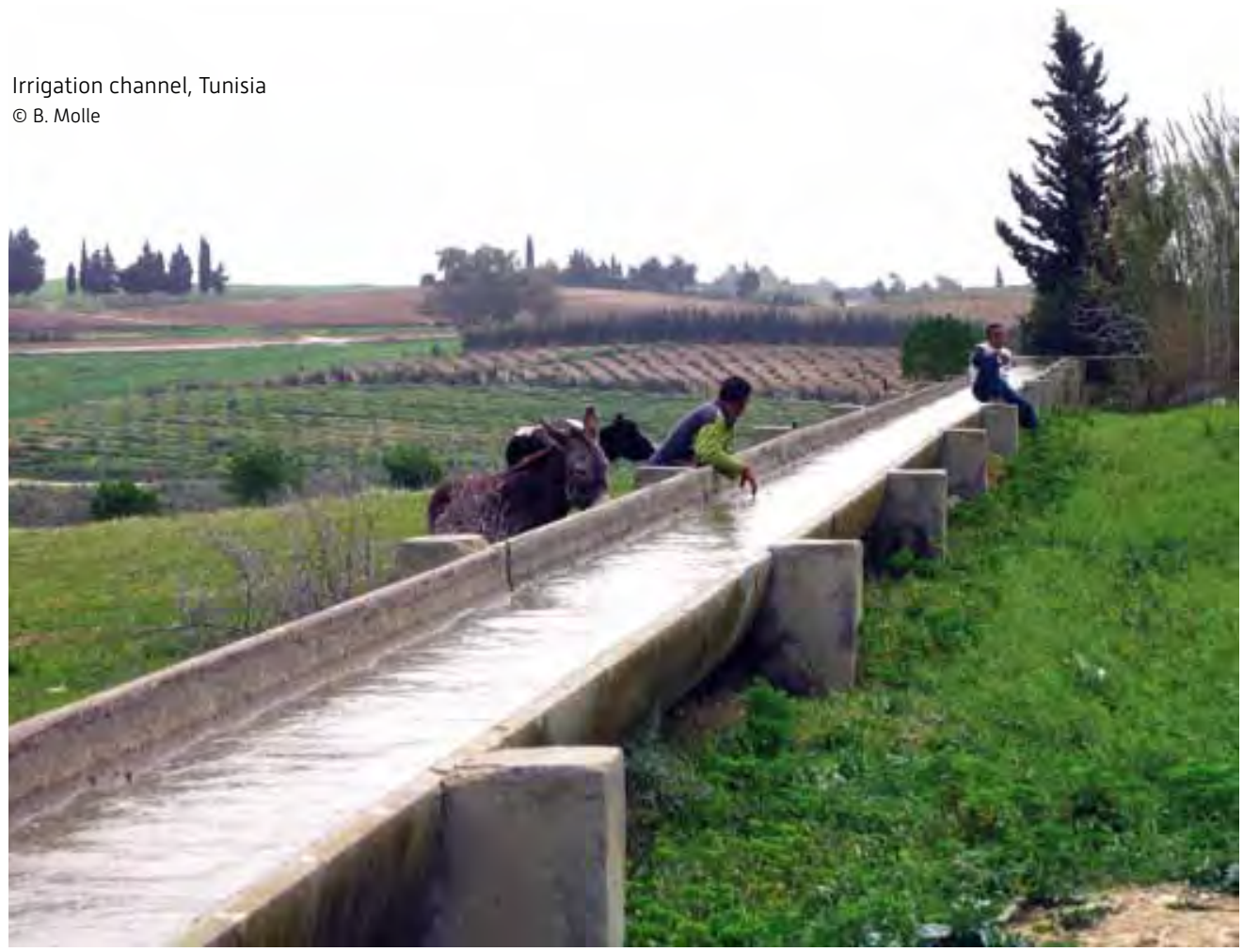

Trigated farming, which accounts for $70 \%$ of the total extracted water volume in North Africa, is widely practised throughout the region. Moreover, high water consumption gravitational irrigation systems are generally used. Under the SIRMA project, which was conducted from 2004 to 2009, CIRAD and its partners tried to determine the conditions required to change these practices through an observation- and participationbased approach.

\section{An observation-based approach}

CIRAD researchers adopted a participatory observation-based approach aimed at supporting groups of family farmers interested in installing drip irrigation systems. They thus observed structures that were already functional in the farmers' groups and encouraged these farmers to emulate them. In the Tadla region, Morocco, they noted especially that professional milk collection organizations were behind the improvement in milk productivity. These organizations also participate in identifying and funding social projects and thus contribute to improving living conditions within the communities. In large irrigation schemes, it is hard to set 
up such local water management structures. The scientists thus analysed the current organization of the milk sector as a model to be potentially applied for water management.

\section{Water pumping regulation contracts}

Water pumping regulation contracts were the focus of another major research line. In Mitidja, Algeria, farmers extract groundwater to an increasing extent since it is readily available for everyone. However, since there is no usage coordination, this water is pumped without concern about the state of the resource. How could pumping be coordinated? Researchers and farmers addressed this question by discussing how farmers viewed this hidden resource and its functioning. Potential strategies for coordination via common or private wells were considered. The relevant state regulations mainly prescribe pumping bans, but they are not applied. The future of agriculture in the region will clearly depend on a rational combination of the two available water resources: groundwater provides considerable flexibility for irrigation and offsets the rigid aspects of public irrigation networks; while water networks relieve pressure on groundwater and thus serve to preserve this resource for future generations.

\section{Collective irrigation \\ schemes}

Finally, the functioning of public collective irrigation schemes, which are much less efficient than schemes used on private farms, remains a concern for policy-makers. In the oases of southern Tunisia, for instance, researchers have employed a multidisciplinary approach to identify technical constraints, farmers' viewpoints and social and organizational constraints affecting them. The findings gave rise to a support approach to help farmers in solving problems they encounter.

These advances were achieved through the development of interconnected networks that bring together higher education institutions, farmers' organizations, research institutions and consulting agencies. The challenge is now to ensure the consistency and sustainability of these networks by certifying long-term scientific and technical operations. To this end, a partnership water resource research network in North Africa has just been created. It will support young research teams in several countries and give effect to regional water management training projects to provide, for instance, joint supervision of $\mathrm{PhD}$ theses, Master's programmes, courses and vocational training.

Contact > Marcel Kuper,

Water Resource Management, Actors and Uses (UMR G-EAU)

\section{FORFURTHERINFORMATION}

Imache A. et al., 2009. Scénariologie participative : une démarche d'apprentissage social pour appréhender l'avenir de l'agriculture irriguée dans la Mitidja (Algérie). Cahiers agricultures, 18: 417-423. Doi: 10.1684/agr.2009.0324.

Kuper M. et al., 2009. Autonomie et dépendance des irrigants en grande hydraulique : observations de l'action organisée au Maroc et en Algérie. Natures, sciences, sociétés, 17: 248-256. Doi: 10.1051/ nss/2009039.

Kuper M. et al., 2009. Supporting the shift from state water to community water: Lessons from a social learning approach to designing joint irrigation projects in Morocco. Ecology and Society, 14: 19. www.ecologyandsociety.org/vol14/iss1/ art19/. www.eau-sirma.net
PARTNERS

Ecole nationale

d'agriculture

de Meknès

(Morocco), Institut

agronomique et

vétérinaire Hassan II

(Morocco), Institut

agronomique

méditerranéen

(IAM), Institut

de recherche pour

l'ingénierie de

l'agriculture et

de l'environnement

(CEMAGREF),

Institut de

recherche pour

le développement

(IRD), Institut

national agronomique

de Tunisie (INAT),

Institut national

de la recherche

agronomique

d'Algérie (INRA),

Institut national de

recherche en génie

rural, eaux et forêts

(INRGREF, Tunisia)

Gravity-fed irrigation is everywhere in North Africa ๑ B. Molle

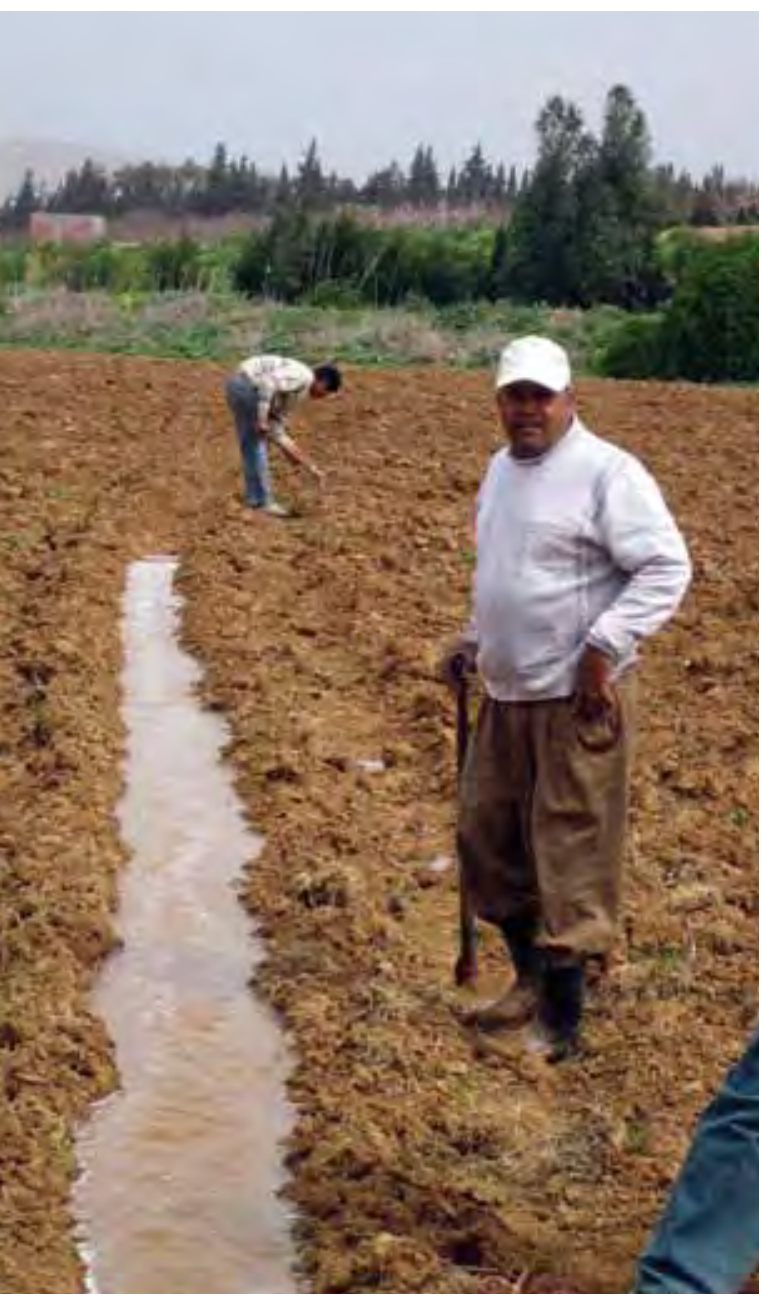




\section{Indicators}

In line with its commitments to its supervising ministries, CIRAD is continuing to implement its Contract of Objectives, which sets out its strategy for the period 2009-2011. The Contract includes four main priorities that will guide CIRAD in the coming years: ensuring shared science in response to the challenges faced by developing countries; producing varied, quality scientific output; opening up national agricultural research operations to Europe and the rest of the world; and tailoring the establishment's structure and resources to current issues.

\section{Ensuring shared science in response to the challenges faced by developing countries}

\section{Share of CIRAD publications according to priority line of research [Agritrop]}

[Articles published in peer-review journals, with or without ISI impact factor]*

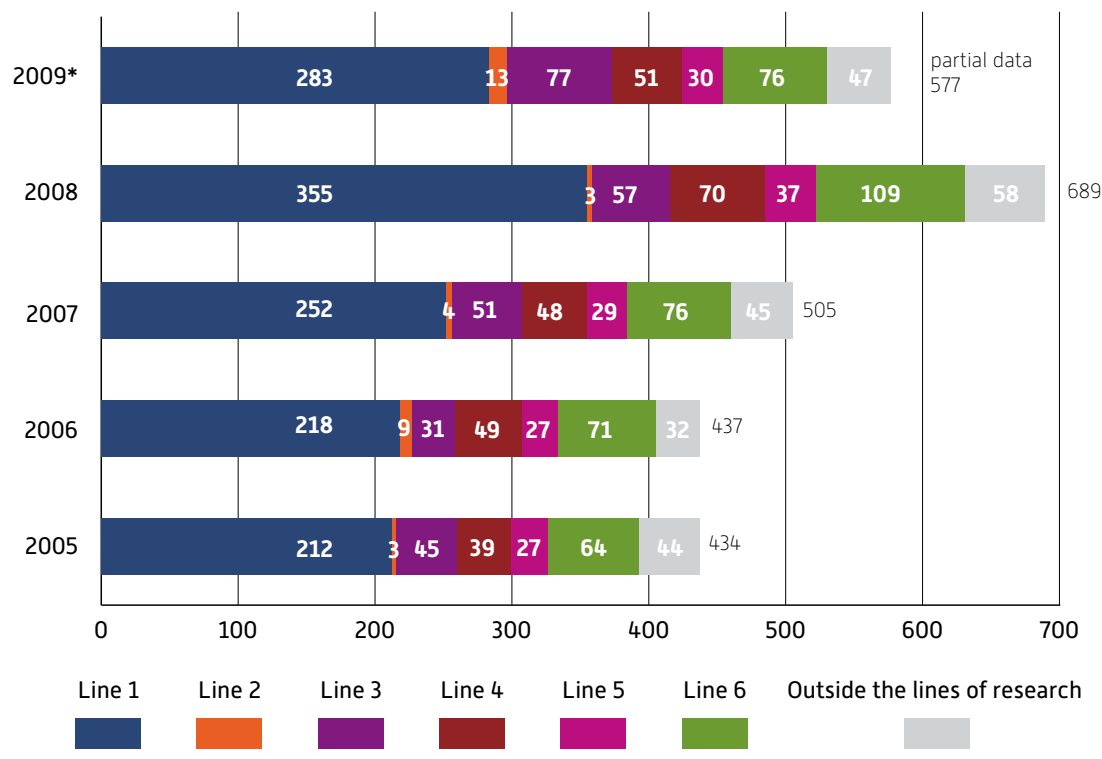

*Publication indicators reflect the status of the institutional database, Agritrop, as of 31 March 2010 at the end of the day. Data and indicators for 2009 are partial

Co-publications with players from developing countries ${ }^{1}$

\begin{tabular}{lccccc}
\hline $\begin{array}{l}\text { Articles published in peer-review journals, } \\
\text { with or without ISI impact factor }\end{array}$ & $\mathbf{2 0 0 5}$ & $\mathbf{2 0 0 6}$ & $\mathbf{2 0 0 7}$ & $\mathbf{2 0 0 8}$ & $\mathbf{2 0 0 9 ^ { 2 }}$ \\
\hline $\begin{array}{l}\text { No. of co-publications with players } \\
\text { from developing countries }\end{array}$ & 181 & 188 & 222 & 305 & 281 \\
\hline $\begin{array}{l}\text { Total publications analysed } \\
\text { Share (\%) of co-publications with players } \\
\text { from developing countries }\end{array}$ & 433 & 437 & 505 & 689 & 577 \\
\hline
\end{tabular}

$1 \mathrm{~A}$ country is classed as developing if it is on the OECD list of countries benefiting from public development aid 2 Partial data, as of 31/03/2010
CIRAD has opted to favour balanced, sustainable partnerships with its scientific partners in developing countries. This is borne out by the share of co-publications with players in developing countries in relation to co-publications as a whole [almost $50 \%$ ], and the steady growth in the proportion of CIRAD co-publications with organizations in developing countries between 2005 and 2009 [from $41.80 \%$ to $48.70 \%$ ], with the partial data for 2009 set to improve. The number of PhD students supervised by CIRAD researchers is up, although the share of students from developing countries has fallen.
Supervision of PhD students by CIRAD researchers

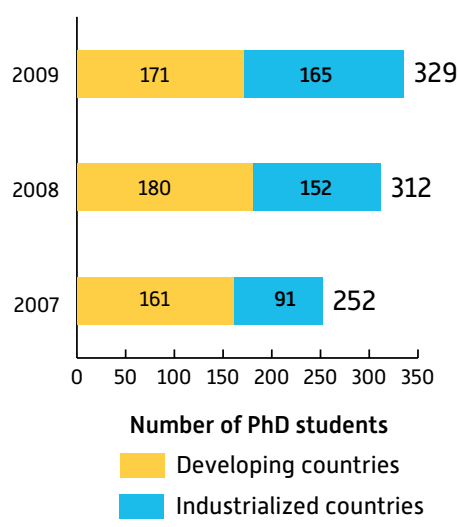




\section{Varied, quality}

\section{scientific output}

To bring science for development up to the very highest scientific level on a global scale, while ensuring that it remains anchored in the issues, areas and partnerships specific to developing countries, CIRAD is boosting the quality of its scientific publications and the competitiveness of its teams, while ensuring the diversity of its outputs aimed at various audiences.

The quality of CIRAD's scientific outputs has increased considerably, notably with the strong growth in the number of articles published between 2005 and 2009 in ISI impact-factor journals, while the level of qualification of CIRAD researchers is also up number of directors of research]. The success rate as regards ANR calls for proposals varies around $30 \%$. At the same time, scientific outputs are becoming more varied, with the involvement of CIRAD staff in training in and through research number of hours' practical work equivalent in Masters courses in developing countries]. Technology transfer and development outputs are up, particularly in 2009.

\section{Distribution of publications in 2008 and 2009 [Total: 3425]}

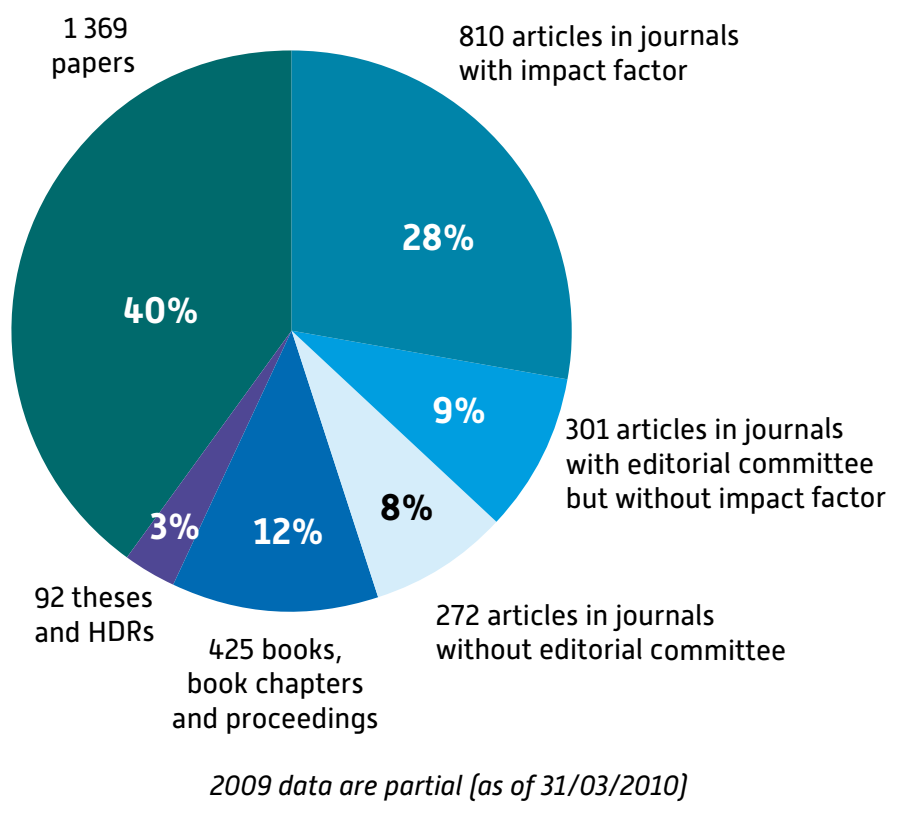

Changes in the number of journal articles published since 2005 [Total: 3371]

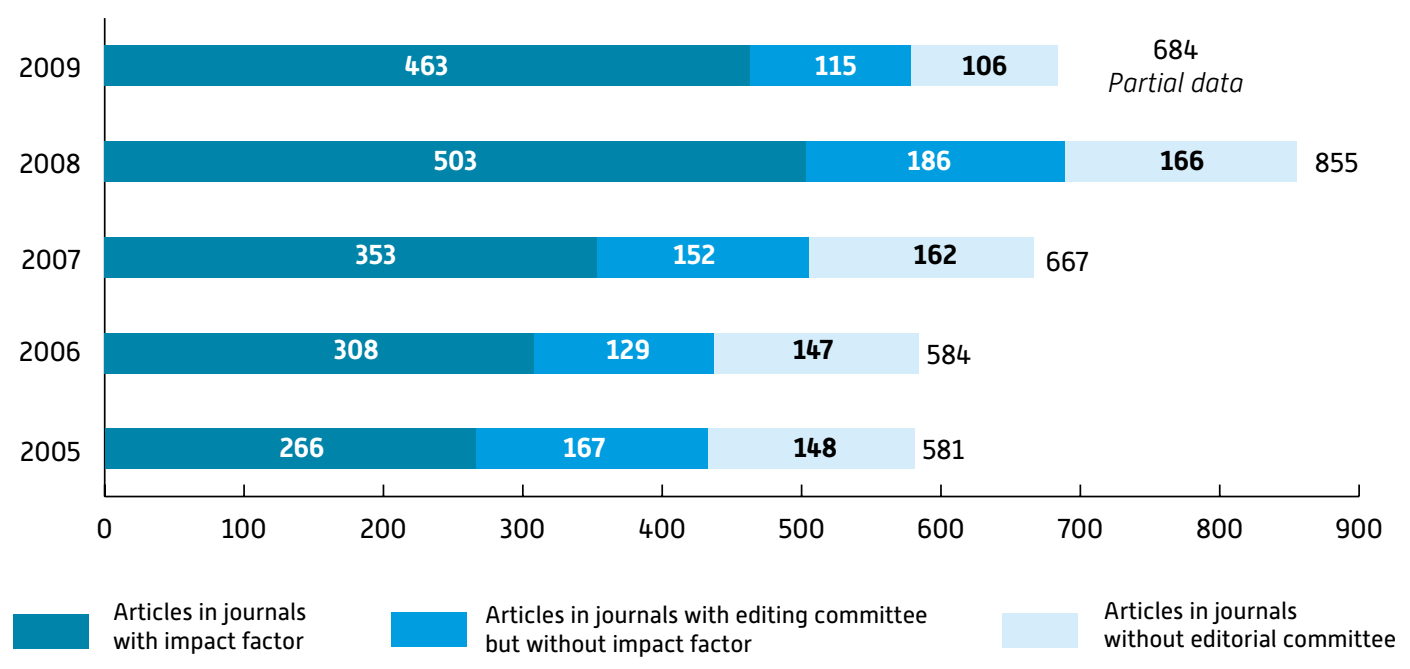


CIRAD participation in ANR competitive calls for proposals

\begin{tabular}{lccc}
\hline & 2007 & 2008 & 2009 \\
\hline $\begin{array}{l}\text { Number of projects } \\
\text { submitted }\end{array}$ & 75 & 72 & 49 \\
\hline $\begin{array}{l}\text { Number of projects } \\
\text { funded }\end{array}$ & 23 & 19 & 14 \\
\hline Success rate [\%] & 31 & 26 & 29 \\
\hline
\end{tabular}

CIRAD participation in teaching and in training engineering for Masters and $\mathrm{PhD}$ courses in developing countries

\begin{tabular}{llll}
\hline 2007 & 2008 & 2009 \\
\hline
\end{tabular}

Number of

hours' practical

work equivalent

$3978 \quad 4249 \quad 4439$

Research training of senior CIRAD scientific staff

\begin{tabular}{lccc}
\hline & 2007 & 2008 & 2009 \\
\hline $\begin{array}{l}\text { Number of directors } \\
\text { of research at CIRAD }\end{array}$ & 82 & 88 & 99 \\
\hline $\begin{array}{l}\text { Number of consulting } \\
\text { professors at CIRAD }\end{array}$ & nc & 36 & 52 \\
\hline
\end{tabular}

Technology transfer and development: patents, plant variety protection certificates and softwares

\begin{tabular}{lccc}
\hline & 2007 & 2008 & 2009 \\
\hline Number* & $8[2]$ & $13[0]$ & $26[4]$ \\
\hline
\end{tabular}

State of the variety of CIRAD scientific outputs

The range of outputs presented above is proof of the variety of missions and operations accomplished by CIRAD. At the request of its Science Council, CIRAD has developed a pilot indicator of output diversity, in the form of a star diagram. It is the result of a selection of outputs, which are weighted: firstly publications [articles published in ISI impact-factor journals [IF articles]), PhD students supervised [PhD students], hours of Masters and PhD teaching [HPWE], and participation in ANR and EU FP7 competitive projects [projects] with, on the left, activities directly devoted to researchers from developing countries, and on the right, those concerning researchers from industrialized countries. There are also outputs that cannot be split North/South: production of books, registration of patents, PVPCs and softwares, MTA (Material Transfer Agreement) declarations, and contracts funded by the public sector and by the private sector.

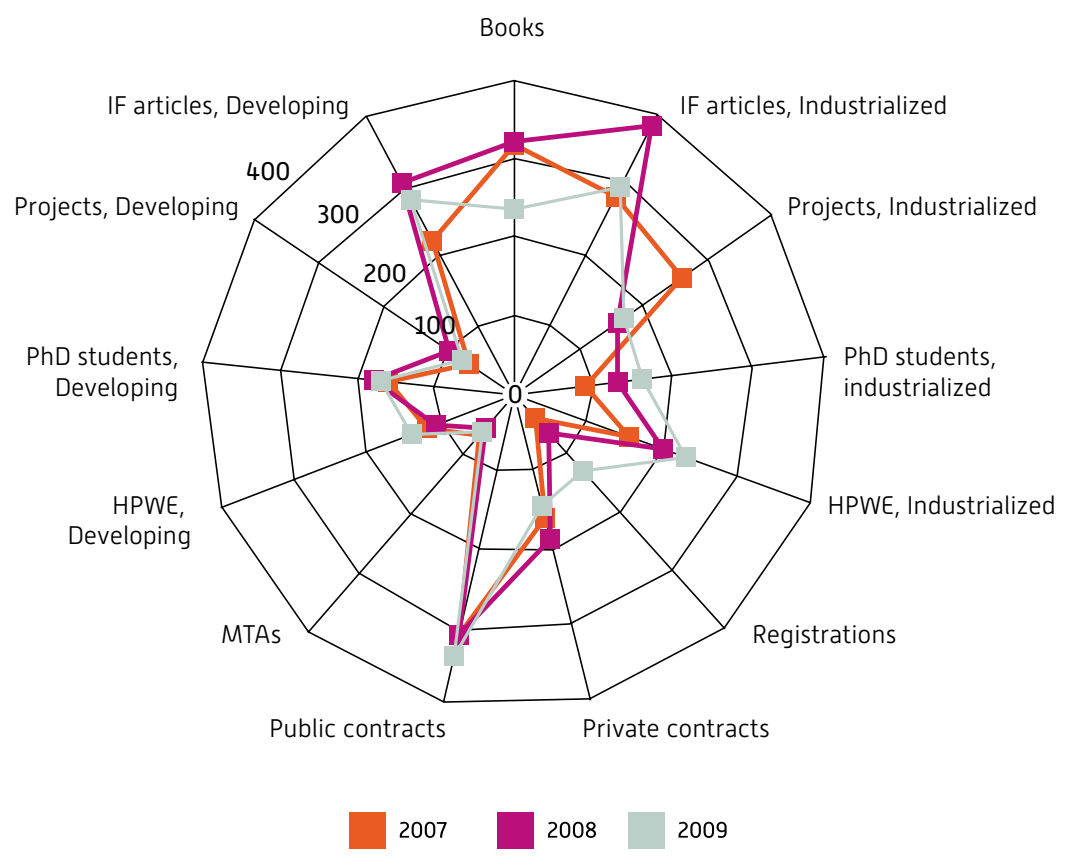

*In brackets, number of patents

\section{National agricultural research operations open to Europe and the rest of the world}

CIRAD has been working on several levels since 2008: in France, within its alliance with INRA and other research organizations under Programme 187 in particular; within regional networks reintegrated into the planned national consortium, which took shape in 2009; in Europe, through strengthened partnerships; and globally, through an in-depth debate at CIRAD about its operational structure and its links with the Consultative Group on International Agricultural Research [CGIAR]. This work is reflected in co-publications, staff assignments and missions in the French overseas departments and abroad, the recent identification of priority research platforms, and participation in $E U$ research projects. 
Co-publications with French, EU or global players

\begin{tabular}{|c|c|c|c|c|c|}
\hline $\begin{array}{l}\text { Articles in peer-review journals, } \\
\text { with or without ISI impact factor }\end{array}$ & 2005 & 2006 & 2007 & 2008 & $\begin{array}{l}2009 \\
\text { Partial as of } 30 / 03 / 2010\end{array}$ \\
\hline No. of co-publications with French players & 179 & 198 & 246 & 315 & 270 \\
\hline $\begin{array}{l}\text { No. of co-publications with European players } \\
\text { [EU27), excluding France }\end{array}$ & 44 & 46 & 59 & 105 & 72 \\
\hline $\begin{array}{l}\text { No. of co-publications with global players, } \\
\text { excluding EU } 27^{*}\end{array}$ & 211 & 210 & 252 & 363 & 317 \\
\hline Total publications analysed $[* *]$ & 433 & 437 & 505 & 689 & 577 \\
\hline
\end{tabular}

[*]Source OST, "Pays-13" table

$\left.{ }^{* *}\right]$ Co-publications are calculated by full counting. As a result, they are not additive: a given article may be co-signed by a French player and a global player

CIRAD co-publications with each organization involved in LOLF Programme 187

\begin{tabular}{lccccc}
\hline $\begin{array}{l}\text { Articles in peer-review journals, } \\
\text { with or without ISI impact factor }\end{array}$ & $\mathbf{2 0 0 5}$ & $\mathbf{2 0 0 6}$ & $\mathbf{2 0 0 7}$ & $\mathbf{2 0 0 8}$ & $\begin{array}{c}\mathbf{2 0 0 9} \\
\text { Partial as of 30/03/2010 }\end{array}$ \\
\hline INRA & 56 & 75 & 101 & 141 & 97 \\
\hline IRD & 33 & 40 & 62 & 50 & 55 \\
\hline CEMAGREF & 4 & 3 & 5 & 16 & 13 \\
\hline IFREMER & 0 & 0 & 2 & 0 & 1 \\
\hline BRGM & 0 & 0 & 0 & 0 & 0 \\
\hline $\begin{array}{l}\text { Total articles in peer-review journals, } \\
\text { with or without ISI impact factor * }\end{array}$ & 433 & 437 & 505 & 689 & 577 \\
\hline
\end{tabular}

(*)The values in the table were calculated by full counting. As a result, they are not additive: a given article may be co-signed by an INRA laboratory and an IRD laboratory

Distribution of assignments to developing countries [in full-time-post equivalents]

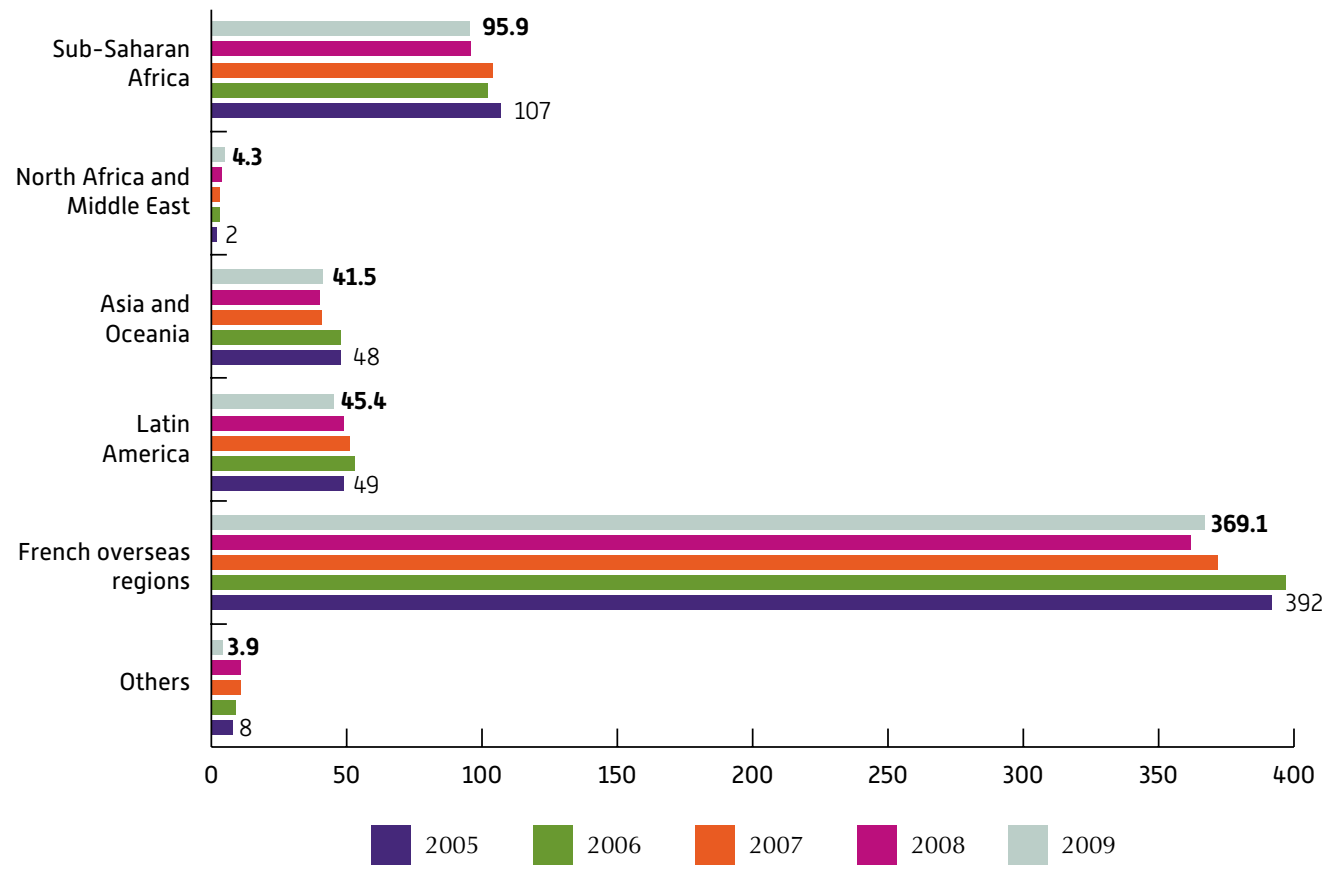




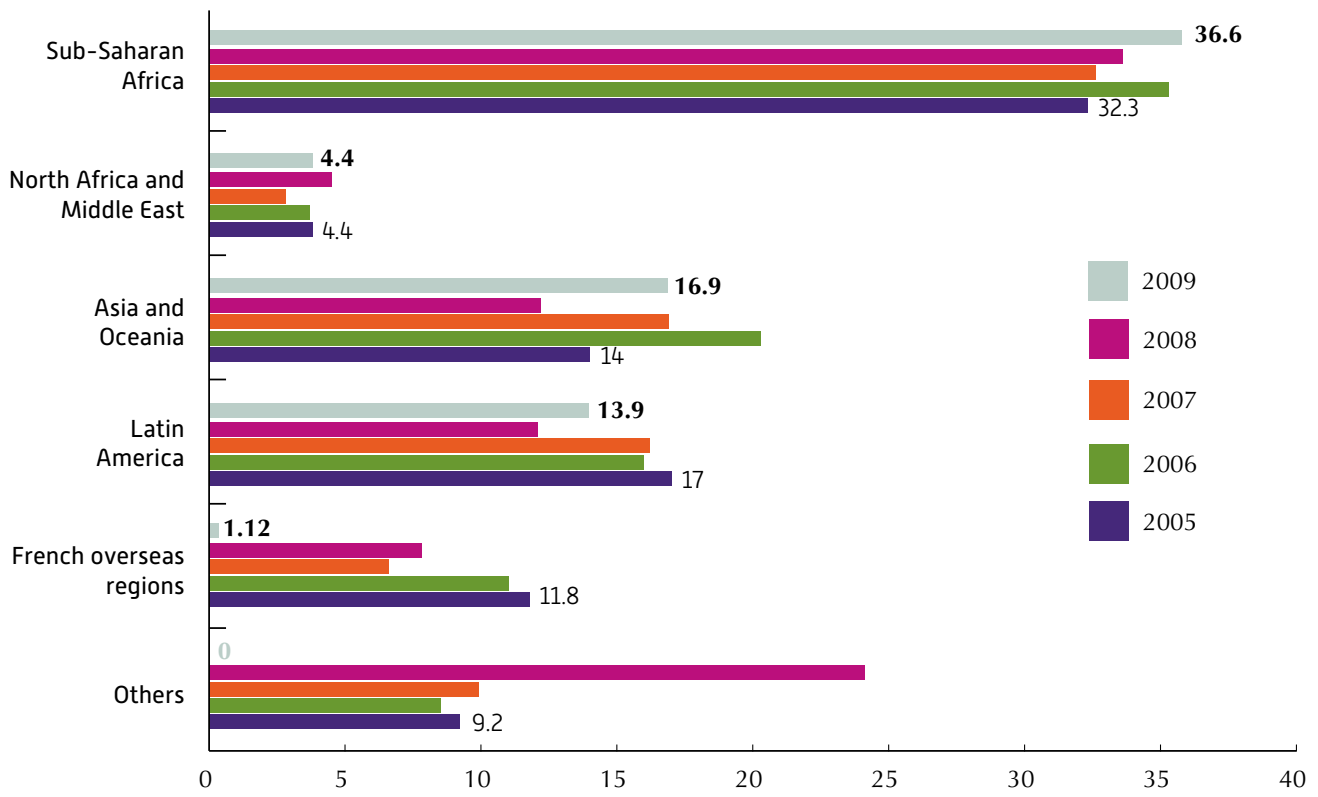

Number of senior scientific staff members assigned to priority research platforms/ number of expatriate senior scientific staff members [full-time-post equivalents]

2008: 111 senior scientific staff members at 18 priority research platforms out of 291 expatriate senior scientific staff members

2009: 137 senior scientific staff members at 20 priority research platforms out of 267 expatriate senior scientific staff members

\begin{tabular}{|c|c|c|c|c|}
\hline Region & $\begin{array}{c}\text { National priority } \\
\text { research platforms [PRPs] }\end{array}$ & Regional PRPs & DOM* & $\begin{array}{l}\text { PRPs } \\
\text { in DOM }\end{array}$ \\
\hline \multicolumn{5}{|l|}{ Africa } \\
\hline & URP PPZS, Senegal & CIRDES, West Africa & Réunion & $3 \mathrm{P}$ \\
\hline & PRP-PCP, Zimbabwe & $2 I E$, West Africa & & Réagir \\
\hline & CR2PI, Congo & PRASAC, central Africa & & Kappa \\
\hline & PCP Grand Sud Cameroun & CARBAP, central Africa & & \\
\hline & URP SCRID, Madagascar & $\begin{array}{l}\text { Congo Basin forests, } \\
\text { central Africa }\end{array}$ & & \\
\hline & $\begin{array}{l}\text { URP Forêt Biodiversité, } \\
\text { Madagascar }\end{array}$ & $\begin{array}{l}\text { Sorghum biodiversity, } \\
\text { Africa }\end{array}$ & & \\
\hline \multicolumn{5}{|l|}{ Asia } \\
\hline & $\begin{array}{l}\text { MALICA PCP, } \\
\text { Vietnam }\end{array}$ & $\begin{array}{l}\text { RCP CANSEA [RACASE], } \\
\text { Southeast Asia }\end{array}$ & & \\
\hline \multicolumn{5}{|c|}{ PRISE PCP, Vietnam } \\
\hline \multicolumn{5}{|c|}{ HRPP PCP, Thailand } \\
\hline \multicolumn{5}{|c|}{ Latin America } \\
\hline \multicolumn{5}{|c|}{$\begin{array}{c}\text { "Agroforestry Systems } \\
\text { with Perennial Crops" PCP, } \\
\text { central America }\end{array}$} \\
\hline \multicolumn{5}{|c|}{ CIBA, Brazil } \\
\hline \multicolumn{5}{|c|}{ Mediterranean } \\
\hline \multicolumn{5}{|c|}{ SIRMA RCP, Maghreb } \\
\hline \multicolumn{5}{|l|}{ Global } \\
\hline \multicolumn{5}{|c|}{ Animal health and emerging diseases } \\
\hline
\end{tabular}

There has been an increase in the number of missions in 2009, in Africa, Asia and the Mediterranean, at the expense of Latin America and the French overseas departments, the latter of which has seen an increase in the number of assignments. The proportion of senior scientific staff members based at priority research platforms is up, from $38.1 \%$ [2008) to $51.3 \%$ [2009] of expatriate senior scientific staff members.

\section{CIRAD EU research and development [FP] projects between 2007 and 2009}

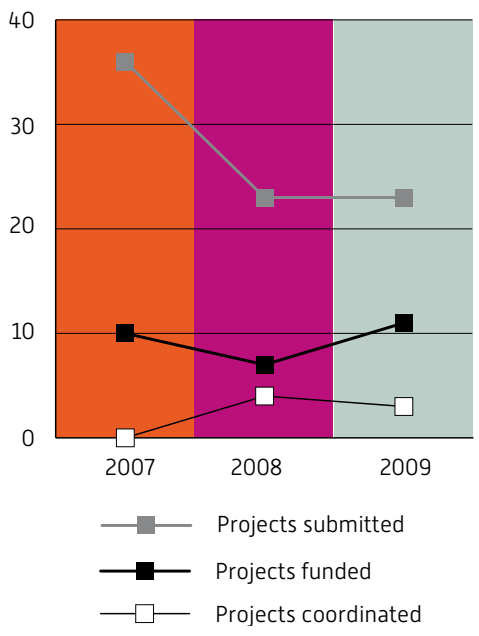




\section{A structure and resources \\ tailored to current issues}

In addition to simplifying and modernizing its management methods, guided by its scientific objectives, CIRAD has also set out to optimize its human and financial resources through stabilization.

The year 2009 is characterized by a rise in the share of publicsector contractual resources in relation to its self-generated income, an increase in the proportion of senior staff members and grant-funded $\mathrm{PhD}$ students in relation to the total number of jobs, which is stable overall, while the extension of the quality approach adopted by the establishment is proof of a collective commitment to progress.

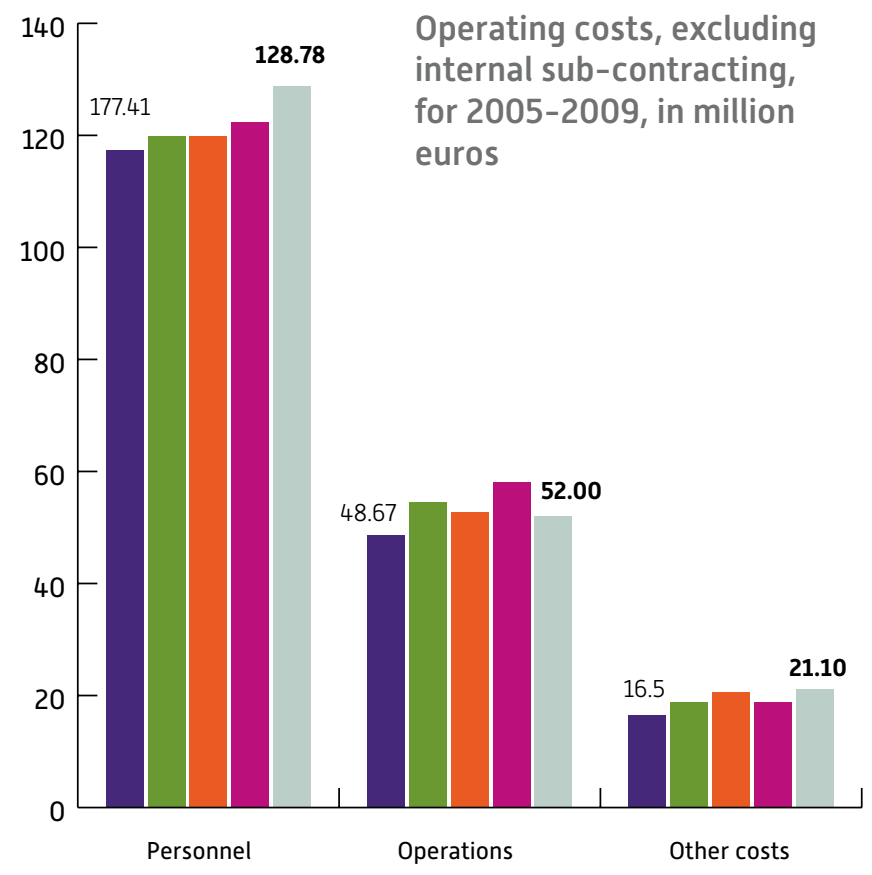

Annual breakdown of "classified, paid" jobs per category, as a percentage (including grant-funded PhD students with CIRAD contracts]

\begin{tabular}{lccc}
\hline & 2007 & 2008 & 2009 \\
\hline Senior staff members & 59 & 58.8 & 59.2 \\
\hline Grant-funded PhD students & 1.3 & 2.7 & 3.9 \\
\hline White-collar staff members & 31.6 & 31.8 & 31.4 \\
\hline Ancillary staff members & 8 & 6.7 & 5.5 \\
\hline
\end{tabular}

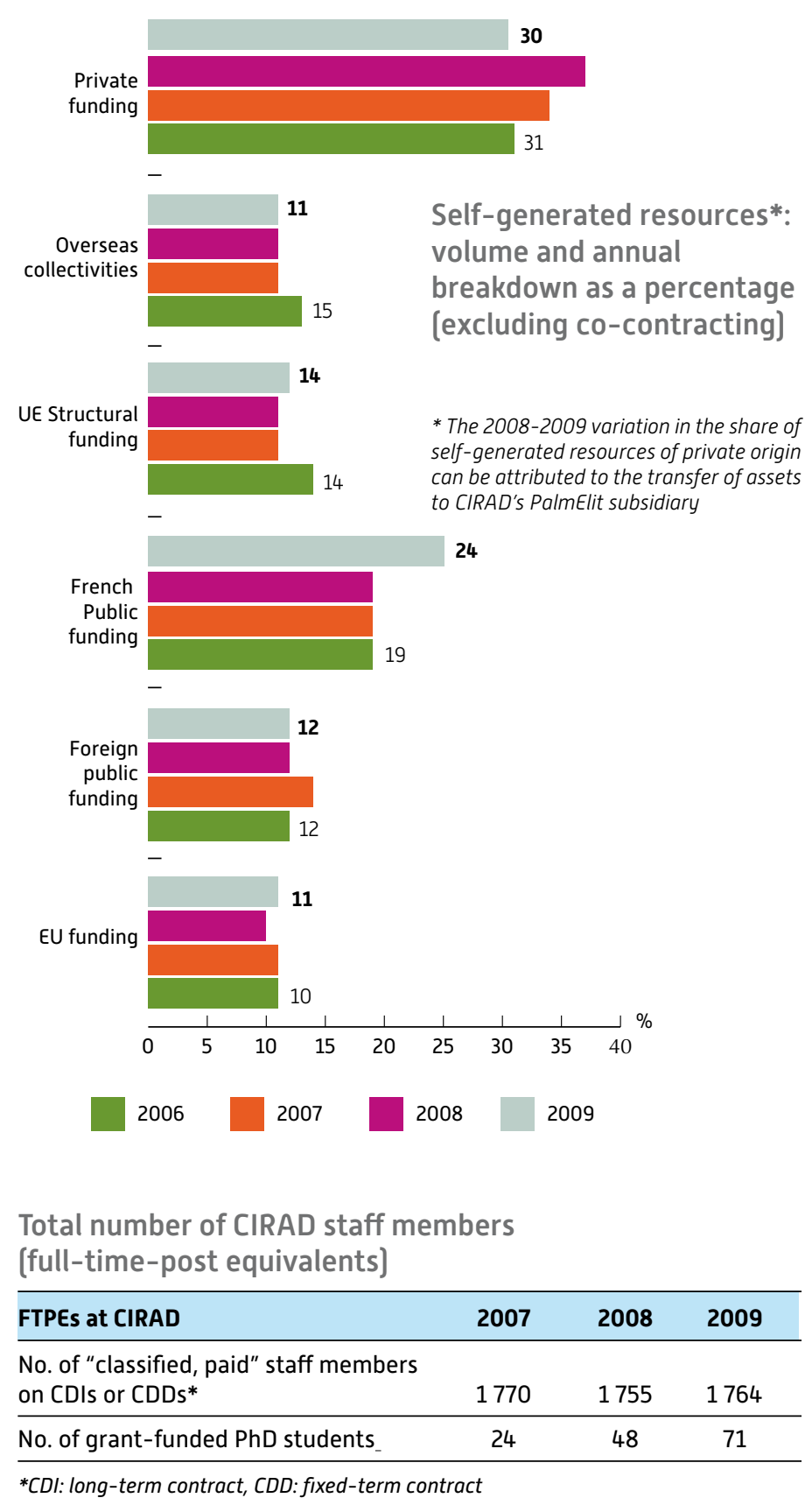

Number of units [in terms of staff numbers] applying a quality approach

\section{7}

2008

2009

Number of units (in terms of staff

numbers) applying a quality approach

(levels $1 / 2$ to 5 )

$375 \quad 444 \quad 853$

Units with ISO certification

115

$268 \quad 430$




\section{Organization in April 2010}

\section{Board of Trustees}

Chair

Patrice Debré, university professor

Bernard Commère, representing the Minister of Higher Education and Research

Hélène Tréheux-Duchêne, representing the Minister with responsibility for Cooperation and Development

Stanislas Godefroy, representing the Minister for the Budget, Public Accounts and the Civil Service Marion Zalay, representing the Minister of Agriculture and Fisheries

$\mathrm{X}$, representing the Minister with responsibility for Overseas Regions

Jean-François Girard, State Councillor

Marion Guillou, President, Institut national de la recherche agronomique Christiane Lambert, Vice-President, Fédération nationale des syndicats d'exploitants agricoles, President, Vivea

Haïdara Lansry Nana Yaya, Commissioner for Food Security, Mali

Jean-Michel Severino, Director General, Agence française de développement

Laurence Tubiana, Director, Institut du développement durable et des relations internationales

Martine Antona, elected staff representative

Michel Benoit-Cattin, elected staff representative

Patrick d'Aquino, elected staff representative

Laurence Ollivier, elected staff representative

Laurent Maggia, elected staff representative

Philippe Vaast, elected staff representative

Secretary, Jean-Louis Muron Writer, Pierre-Luc Pugliese

\section{Science Council}

Chair

Bertrand Hervieu, Conseil général de l'agriculture, de l'alimentation et des espaces ruraux

Akissa Bahri, International Water Management Institute, Ghana

Bernard Chevassus-au-Louis, Institut national de la recherche agronomique, France

Marie-Christine Cormier-Salem, Institut de recherche pour le développement, France

Michel Dron, University of Paris XI, France

Bernadette Kamgnia Dia, University of Yaounde II, Cameroon

Olivier Le Gall, Institut national de la recherche agronomique, France Claudine Schmidt-Lainé, Institut de recherche pour l'ingénierie de l'agriculture et de l'environnement, France

Lamine Seiny Boukar, Pôle régional de recherche appliquée au développement des savanes d'Afrique centrale, Chad

Marco Wopereis, Africa Rice Centre, Benin

Marie-Line Caruana, elected staff representative

Régis Goebel, elected staff

representative

Raphaël Morillon, elected staff representative

Vincent Ribier, elected staff representative

Guy Trébuil, elected staff representative

\section{INRA-CIRAD Joint Consultative Committee on Ethics in Agricultural Research \\ Chair \\ Louis Schweitzer, Haute autorité de lutte contre les discriminations et pour l'égalité}

Fifi Benaboud, North-South Centre, Council of Europe

Gilles Bœuf, lecturer at Pierre et

Marie Curie University, Chair of the Science Council of the Muséum national d'histoire naturelle

Marcel Bursztyn, socioeconomist, university professor
Claude Chéreau, historian, honorary Inspector General of Agriculture Soraya Duboc, agrifood scientist, Nestlé France

Patrick Du Jardin, agronomist, lecturer at and Dean of the University of Gembloux

Catherine Larrère, lecturer in applied ethics at the University of Paris I

Panthéon-Sorbonne

Jeanne-Marie Parly, associate professor of economic science

Gérard Pascal, nutritionist, honorary director of research

Lazare Marcelin Poamé, Dean of the Arts and Human Sciences Training and Research Unit at the University of Bouaké, Chair of the National

Consultative Committee on

Bioethics, Ivory Coast

Gérard Toulouse, agrégé in science, director of research, Theoretical Physics Laboratory, Ecole normale supérieure

Dominique Vermersch, agronomist, lecturer in public economics and ethics, Agrocampus Rennes Heinz Wismann, philosopher and philologist, lecturer at the Ecole des hautes études en sciences sociales

\section{Office of}

\section{the Director General}

Gérard Matheron, Director General

Jacques Pagès, Deputy Director

General

Jean-Louis Muron, adviser

Alain Weil, adviser

Michel Griffon, adviser

Patrick Herbin, Regional Director, Ile-de-France

Emmanuel Camus, Regional Director, Languedoc-Roussillon Gilles Mandret, Regional Director, Réunion-Mayotte

Philippe Godon, Regional Director, West Indies-French Guiana

Anne Hébert, Coordinator

Communication

Anne-Yvonne Le Dain, Coordinator, Evaluation

Léandre Mas, Coordinator, Quality Joël Sor, Coordinator, Information Systems

\section{Office of}

the Director of Research and Strategy

Etienne Hainzelin, Director

Jean-Luc Khalfaoui, Associate

Director, Head of European and

International Relations

André de Courville, Coordinator, Latin America and Caribbean

Rolland Guis, Coordinator, Africa and Indian Ocean

Christian Hoste, Deputy Head of European and International

Relations, Coordinator, European and International AR4D System

Catherine Marquié, Coordinator,

European Community

Michel Trebel, Coordinator,

Mediterranean Countries and Near

East

Marie-Claude Deboin, Coordinator, Scientific and Technical Information

Claudie Dreuil, Coordinator,

Incentive Operations

Rémy Hugon, Coordinator,

Technology Transfer and

Development

Mireille Mourzelas, Coordinator, Higher Education and Training

Hubert Omont, Coordinator,

Tropical Supply Chains

Jean-Louis Sarah, Coordinator, Strategic Operations

\section{Office of}

the Director of Finance

\section{and Administration}

Hervé Deperrois, Director of Finance and Administration

Patrick Herbin, Deputy Director of Finance and Administration, Legal Adviser

Marc Gélis, Manager, Accounts and Finance

Vincent Fabre-Rousseau, Manager, Human Resources

Didier Servat, Technical Manager, Installations and Maintenance

André Nau, Management

Supervision Officer

Aleth de Sartiges, Safety Officer

Yann Combot, Archives Officer 


\section{Research Departments and Units}

\section{Biological Systems Department}

Jean-Christophe Glaszmann, Director

Dominique Berry, Deputy Director

Xavier Mourichon, Associate

Director

Jean-Marc Deboin, Financial Affairs

Manager

\section{Research Units*}

Agro-ecological Adaptation and Varietal Innovation (UPR), Michael Dingkuhn

Biology and Genetics of PlantPathogen Interactions for Integrated Protection (UMR BGPI), Jean-Loup Notteghem, SupAgro (SupAgro, INRA)

Botany and Computational Plant Architecture (UMR AMAP), Daniel Barthélémy, INRA (CNRS, INRA, IRD, University of Montpellier II, EPHE)

Centre for Biology and Management of Populations (UMR CBGP), Denis Bourguet, INRA (SupAgro, INRA, IRD, University of Montpellier II)

Centre of Evolutionary and Functional Ecology (UMR CEFE), Jean-Dominique Lebreton, CNRS (CNRS, Universities of Montpellier I, II and III, SupAgro, EPHE)

Coconut Lethal Yellowing and Citrus Greening (UPR), Michel Dollet

Controlling Pests and Diseases in Tree Crops (UPR), Christian Cilas Diversity and Adaptation of Cultivated Plants (UMR DIAPC), Serge Hamon, IRD (IRD, SupAgro, INRA, University of Montpellier II)

Emerging and Exotic Animal Disease Control (UMR),

Dominique Martinez (INRA)

Genetic Diversity and Breeding of Forest Species (UPR), Jean-Marc Bouvet

Genetic Improvement of Vegetatively Propagated Crops (UPR), Robert Domaingue

Laboratory of Tropical and Mediterranean Symbioses (UMR LSTM), Michel Lebrun, University of Montpellier II (SupAgro, INRA, IRD, University of Montpellier II)

Locust Ecology and Control (UPR), Michel Lecoq
Oil Palm Breeding (UPR), Jean-Marc Bouvet

Plant Communities and Biological Invaders in Tropical Environments (UMR PVBMT), Bernard Reynaud (University of Réunion)

Plant Development and Genetic Improvement (UMR DAP), Emmanuel Guiderdoni (SupAgro, INRA, University of Montpellier II) Plant Resistance to Parasites (UMR RPB), Michel Nicole, IRD (IRD, University of Montpellier II Trypanosomes (UMR), Gérard Cuny, IRD (IRD)

\section{Performance of Tropical} Production and Processing Systems Department

Robert Habib, Director

Marcel de Raïssac, Deputy Director

André Rouzière, Associate Director Jacques Nolin, Financial Affairs Manager

\section{Research Units*}

Agro-ecological Functioning and Performances of Horticultural Cropping Systems (UPR), Eric Malézieux

Agropolymer Engineering and Emerging Technologies (UMR IATE), Xavier Rouau, INRA (SupAgro, INRA, Universities of Montpellier II and II, ENSIA) Annual Cropping Systems (UPR), Florent Maraux

Aquaculture and Aquatic Resource Management (UPR),

Jean-François Baroiller

Banana, Plantain and Pineapple Cropping Systems (UPR),

François Côte

Biomass and Energy (UPR), Sylvie Mouras

Cattle Rearing (UMR ERRC), François Bocquier, SupAgro (SupAgro, INRA)

Direct Seeding and Cover Crops (UPR), Francis Forest)

Environmental Risks of Recycling (UPR), Hervé Saint Macary

Functioning and Management of Tree-Based Planted Ecosystems (UPR), Jean-Michel Harmand Integrated Food Quality System (UMR QUALISUD,

Max Reynes (Universities of Montpellier I and II, SupAgro)
Performance of Tree Crop-Based Systems (UPR), Eric Gohet

Process Engineering and Bioproduct

Development (UMR GPEB),

Alain Grasmick, University

of Montpellier II (Universities of

Montpellier I and II)

Production and Processing of

Tropical Woods (UPR), Jean Gérard

Tropical and Mediterranean

Cropping System Functioning and Management (UMR SYSTEM),

Jacques Wery, SupAgro (SupAgro,

INRA)

Water, Soil and Plant Analysis (US), Alain Aventurier

\section{Environment and Societies Department \\ Patrick Caron, Director \\ Brigitte Nésius, Financial Affairs Manager}

\section{Research Units*}

Animal and Integrated Risk

Management (UPR),

Marie-Noël de Visscher

Centre for International Research on Environment and Development (UMR CIRED),

Jean-Charles Hourcade,

CNRS-EHESS (CNRS, EHESS,

ENGREF, ENPC)

Collective Action, Policies and Markets (UPR), Denis Pesche

Ecology of the Forests of French

Guiana (UMR ECOFOG),

Eric Marcon, CNRS (CNRS,

ENGREF, INRA, Antilles-Guyane

University)

Innovation and Development in

Agriculture and the Agrifood Sector

(UMR Innovation),

Hubert Devautour (SupAgro, INRA)

Livestock Systems and Animal

product Management (UPR),

Philippe Lecomte

Management of Renewable

Resources and Environment (UPR), Martine Antona

Markets, Organizations, Institutions and Operators' Strategies (UMR MOISA),

Etienne Montaigne, CIHEAM (SupAgro, INRA, CIHEAM)

Spatial Information and Analysis for Territories and Ecosystems (UMR TETIS), Pascal Kosuth, CEMAGREF (CEMAGREF, ENGREF)
Tropical Forest Goods and Ecosystem Services: Facing Global Change (UPR), Alain Billand

Water Management, Stakeholders and Uses (UMR G-EAU), Patrice Garin, CEMAGREF (CEMAGREF, ENGREF, IRD, SupAgro, IAMM)

* UMR: Joint Research Unit UPR: Internal Research Unit US: Service Unit 


\section{CIRAD worldwide}

\section{France}

Ile-de-France

Patrick Herbin, Regional Director 42, rue Scheffer

75116 Paris

Tel.: +33153702021

patrick.herbin@cirad.fr

\section{Languedoc-Roussillon}

Emmanuel Camus, Regional Director Avenue Agropolis 34398 Montpellier Cedex 5

Tel.: +33467615801

emmanuel.camus@cirad.fr

\section{Réunion-Mayotte}

Gilles Mandret, Regional Director Station de La Bretagne, BP 20 97408 Saint-Denis Messageries Cedex 9,

Réunion

Tel.: +262 $262528100 /$ +262692

763069

gilles.mandret@cirad.fr

Bernard Dolacinski, Correspondent BP 1304

97600 Mamoudzou, Mayotte

Tel.: +269612121

bernard.dolacinski@cirad.fr

\section{West Indies-French Guiana}

Philippe Godon, Regional Director Station de Neufchâteau, Sainte-

Marie

97130 Capesterre-Belle-Eau,

Guadeloupe

Tel.: +590590861790/+069445 1022

philippe.godon@cirad.fr

Richard Pasquis, Correspondent BP 701, avenue de France 97387 Kourou Cedex, French Guiana Tel.: +594594327352 richard.pasquis@cirad.fr

Christian Chabrier, Correspondent BP 214

97285 Le Lamentin Cedex 2,

Martinique

Tel.: +596596423044

christian.chabrier@cirad.fr

\section{Africa}

\section{Central Africa}

Jean-Luc Battini, Regional Director BP 2572

Yaounde, Cameroon

Tel.: +23722 212541

jean-luc.battini@cirad.fr

Yves Nouvellet, Correspondent

Pointe Noire: Consulate

13, rue Louveau

92438 Chatillon Cedex

Tel.: +2425232592

yves.nouvellet@cirad.fr

Eric Forni, Correspondent

BP 4035

Libreville, Gabon

Tel.: +241074928 21

eric.forni@cirad.fr

\section{Coastal West Africa}

Georges Subreville, Regional Director 37, avenue Jean XXIII BP 6189

Dakar-Etoile, Senegal

Tel.: +221338224484

georges.subreville@cirad.fr

\section{Madagascar}

François Monicat, Regional Director Ampandrianomby, BP 853

Antananarivo

Tel.: +261202240623

francois.monicat@cirad.fr

\section{Continental West Africa}

Michel Partiot, Regional Director 01 BP 596

Ouagadougou 01, Burkina Faso

Tel.: +226 50307070

michel.partiot@cirad.fr

Jacques Lançon, Correspondent

Conseiller auprès du Directeur de

l'INRAB

Ambassade de France

01 BP 966

Cotonou, Benin

Tel.: +22997249657

jacques.lancon@cirad.fr
East and Southern Africa

Denis Depommier, Regional Director

C/o ICRAF, United Nations Avenue

Gigiri, PO Box 30677

00100 Nairobi, Kenya

Tel.: +25420722 4653

denis.depommier@cirad.fr

Emmanuel Torquebiau,

Correspondent

PO Box 26884, Monument Park

0105 Pretoria, South Africa

Tel.: +27 124204318

emmanuel.torquebiau@cirad.fr

Sébastien Le Bel, Correspondent

French Embassy

37, Acturus Road Highlands

PO Box 1378

Harare, Zimbabwe

Tel.: +2634443422

sebastien.le_bel@cirad.fr

\section{Americas}

Brazil

Bernard Mallet, Regional Director SHIS-QI 23, B1. B. Ed. Top 23

71660-120 Brasilia DF

Tel.: +55 6133661132

bernard.mallet@cirad.fr

Central America

Bruno Rapidel, Correspondent

CATIE, Departamento de

Agricultura y Foresteria

CATIE 7170, Cartago

Turrialba, 30501 Costa Rica AP 2382-2050

San Pedro Montes de Oca, Costa

Rica

Tel.: +50625582599

bruno.rapidel@cirad.fr

\section{United States}

Jill Barr, Correspondent

assigned to the World Bank and the

Inter-American Development Bank

Development Research Associates

8313, Woodhaven blvd

Bethesda 20817, Maryland

Tel.: +1 3013656855

jbarr@cirad.fr
Asia

China

Zheng Li, INRA-CIRAD

Permanent Representative

507 Tower A, Fuhua Mansion

8, Chaoyangmen North Avenue

100027 Beijing

Tel.: +86106554 1871

zhengliINRA@sohu.com

Continental Southeast Asia

Jean-Charles Maillard, Regional

Director

CIRAD, Bureau 102, Bâtiment 2G

Cité diplomatique de Van Phuc

$298 \mathrm{Kim} \mathrm{Ma}$

Hanoi, Vietnam

Tel.: +84437346775

jean-charles.maillard@cirad.fr

Antoine Leconte, Correspondent CIRAD Office, Research and

Development Building

3rd floor, Kasetsart University

10900 Bangkok, Thailand

Tel.: +66 29427627 ext. 105

antoine.leconte@cirad.fr

India

Typhaine Loyer, INRA-CIRAD

Correspondent

Scientific Department of the French

Embassy in India

2, Aurangzeb Road

110011 New Delhi

Tel.: +911130410008

typhaine.loyer@cirad.fr

\section{Southeast Asian Island Countries}

Jean-Guy Bertault, Regional Director Plaza Bisnis Kemang, 3rd Floor Jalan Kemang Raya 2 12730 Jakarta Selatan, Indonesia

Tel.: +62 217199067 /

+62 217194601

jean-guy.bertault@cirad.fr

\section{Oceania}

Régis Goebel, Correspondent

PO Box 86

50, Meiers Road

Indooroopilly Q1d. 4068, Australia

Tel.: +61 733313309

francois-regis.goebel@cirad.fr 
Production: Communication Service

Coordination and texts (French version): Martine Lemaire, Danielle Barret (Indicators chapter), with the help of Christine Rawski, Christiane Jacquet, Laurence Dedieu and Christine Nouaille

Translation: Helen Burford-Buttazzoni, David Manley

Editing: Anya Cockle

Graphic design and layout: Patricia Doucet

Cover illustration: Nathalie Le Gall

Printing: Impact Imprimerie, Saint-Gély-du-Fesc

Printed with vegetable inks on paper from sustainable forests

Legal deposit: June 2010 


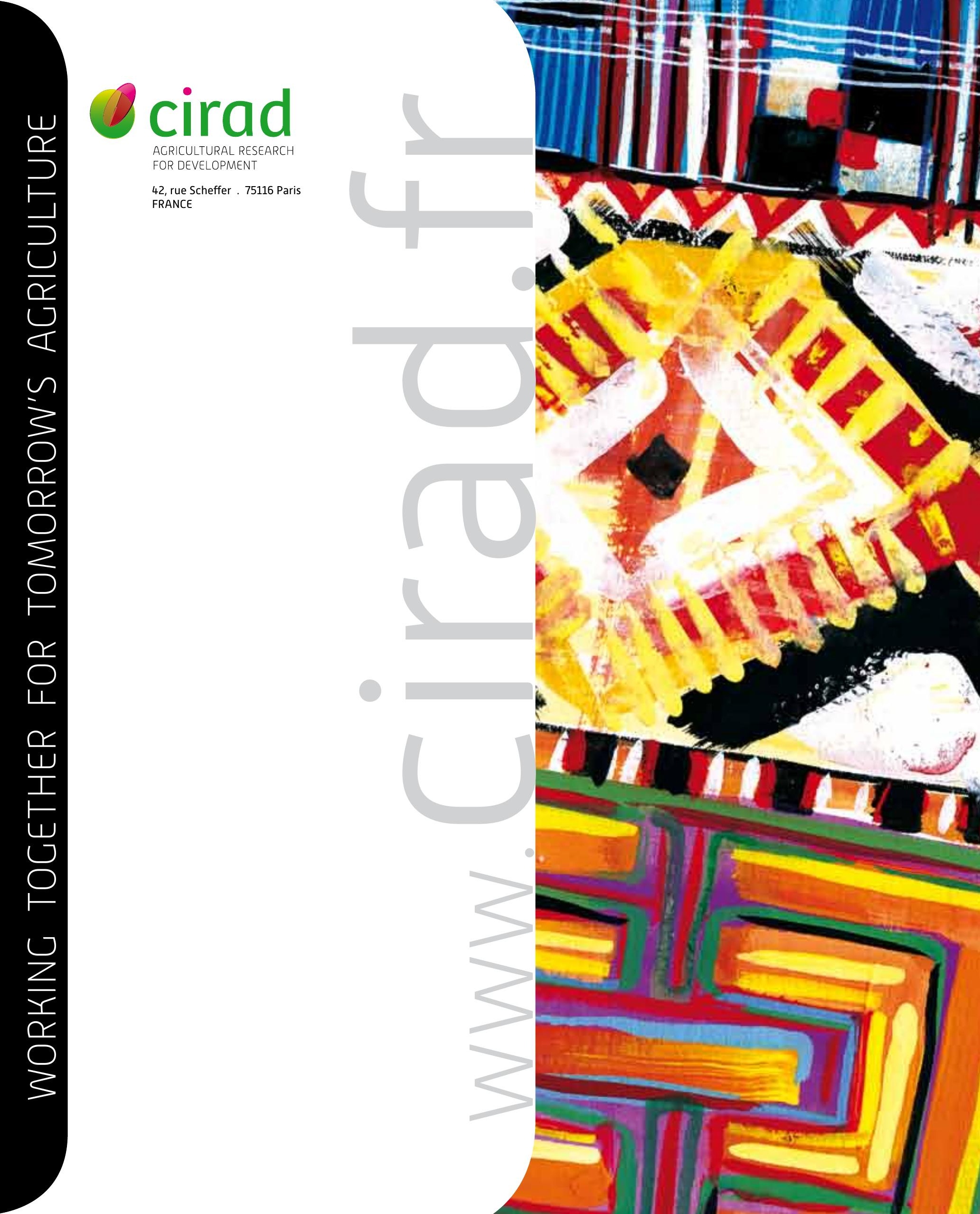

